\title{
AVALIAÇÃO ECONÔMICA DE QUATRO MODELOS AGROFLORESTAIS EM ÁREAS DEGRADADAS POR PASTAGENS NA AMAZÔNIA OCIDENTAL
}

\section{MÁRIO JORGE CAMPOS DOS SANTOS}

Dissertação apresentada à Escola Superior de Agricultura "Luiz de Queiroz", Universidade de São Paulo, para obtenção do título de Mestre em Ciências, Área de Concentração: Ciências Florestais.

\section{PIRACICABA}

Estado de São Paulo - Brasil

Dezembro - 2000 


\section{AVALIAÇÃO ECONÔMICA DE QUATRO MODELOS AGROFLORESTAIS EM ÁREAS DEGRADADAS POR PASTAGENS NA AMAZÔNIA OCIDENTAL}

\section{MÁRIO JORGE CAMPOS DOS SANTOS}

Engenheiro Florestal

\section{Orientador: Prof. Dr. LUIZ CARLOS ESTRAVIZ RODRIGUEZ}

Dissertação apresentada à Escola Superior de Agricultura "Luiz de Queiroz", Universidade de São Paulo, para obtenção do título de Mestre em Ciências, Área de Concentração: Ciências Florestais.

\section{PIRACICABA}

Estado de São Paulo - Brasil

Dezembro - 2000 
Dados Internacionais de Catalogação na Publicação (CIP)

DIVISÃO DE BIBLIOTECA E DOCUMENTAÇÃOO - Campus “Luiz de Queiroz"/USP

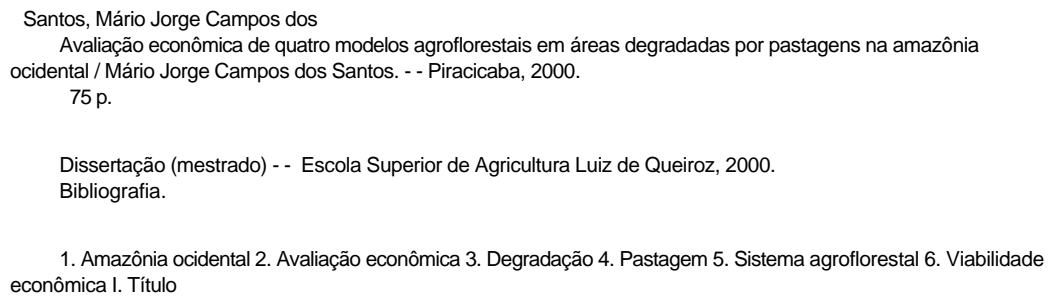

CDD 634.99

\section{"Permitida a cópia total ou parcial deste documento, desde que citada a fonte - $\mathrm{O}$ autor"}


“Árdua é a missão de sesenvolver e defender a Amazônia, porém muito mais difícil foi a de nossos antepassados em conquista-la e mantê-la"

Gen.Ex. Rodrigo Otávio

Dedico este trabalho a minha esposa, Beatriz Cristina de Matteo;

A meu pai, José Luiz dos Santos Neto;

Aos meus irmãos, Ana Maria, José Laurindo, Liliana e a seus familiares.

À minha mãe Waneide Campos dos Santos ${ }^{\text {th }}$

À minha sogra Mirian Kerr Müzel de Matteo ${ }^{\text {th }}$ 


\section{AGRADECIMENTOS}

Registro meus sinceros agradecimentos a todos aqueles que, direta e indiretamente, contribuíram para a execução do presente trabalho sem cujas colaborações o objetivo não teria sido alcançado.

Ao Prof. Dr. Luiz Carlos Estraviz Rodriguez pela orientação, estimulo, criticas e sugestões, sobretudo pela confiança depositada em meu trabalho.

À Universidade de São Paulo-Escola Superior de Agricultura "Luiz de Queiroz" ESALQ/USP, em particular ao Departamento de Ciências Florestais, pelo acolhimento e oportunidade de realizar o curso.

Aos professores e funcionários, em especial a Maria Alice Poggiani, Paulo Beraldo, Thaís Campos e Olicina Ferraz.

À EMBRAPA- Amazônia Ocidental, representado pelo diretor Eduardo Alberto Vilela Morales, juntamente com os pesquisadores do Centro de Pesquisas Agroflorestais, Elisa Wandelli, João Matos, Rogério Perin e Silas Garcia pelo acesso e disponibilidade da pesquisa na Estação Experimental do DAS, bem como pelo apoio e infra-estrutura recebidas, e pela ajuda e amizade do pessoal técnico de campo Mário Kokai e Rubenildo Silva.

À Coordenação de Aperfeiçoamento de Pessoal de Nível Superior(CAPES), pela concessão de bolsa de estudo.

Aos companheiros do curso de mestrado, Alberto (Tora), Adriana (Payakan), Beija-flor, Ciro, Flaviana Maluf, Geraldo, Lucio Mendez (Baiano), Luiz Farias, Marcelino, Maurício (Gnomo) e Paulo Pompermayer, João Dagoberto (Cobrão), Fabiano Rocco, Fábio Sgarbi (Nabo), e Median Pardo. Aos amigos e colaboradores do Departamento de Ciências Florestais e IPEF, Antônio Dirceu, Luiz Erivelton, Jefferson Polizel, Ivo Rosa, Rogério Naressi e José Martins.

Ao Prof. Raymond Pacovsky, pela colaboração e pelas correções no Abstract, e pelos inúmeros auxílios prestados e pela grande disposição em ajudar. Aos professores, Fernando Seixas e Marcos Bernardes pelas importantes sugestões apresentadas durante a pré-banca.

A Deus, que em nenhum momento deixou-me desamparado, dando-me coragem e perseverança. 


\section{SUMÁRIO}

\section{Página}

LISTAS DE FIGURAS.................................................................................. vii

LISTAS DE TABELAS............................................................................. viii

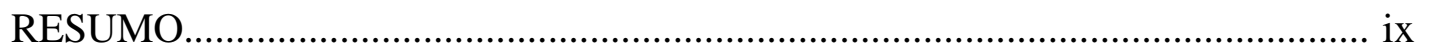

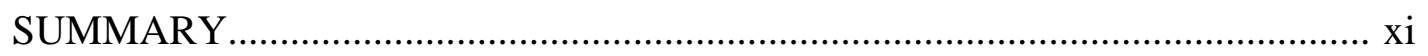

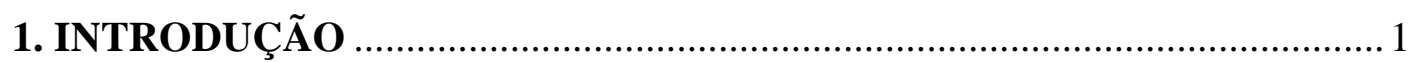

$1.1 \mathrm{O}$ impacto da atividade agrícola na Amazônia............................................. 2

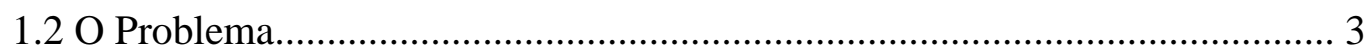

1.3. Hipóteses de Trabalho ........................................................................... 4

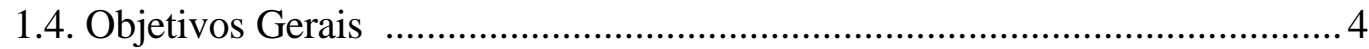

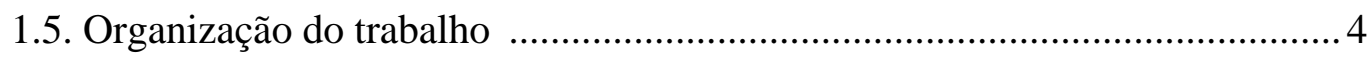

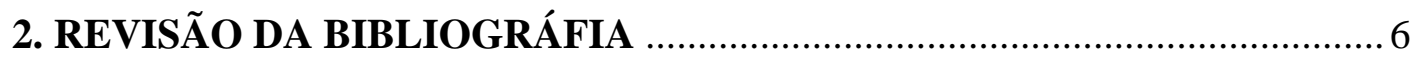

2.1 Degradação da Amazônia causada pela a atividade agropecuária .................. 6

2.2 Histórico das atividades do uso das pastagens .......................................... 7

2.3 Causas da degradação das pastagens ..................................................... 7

2.4 Processo de degradação das pastagens ................................................... 8

2.5 A agricultura na Amazônia ....................................................................... 9

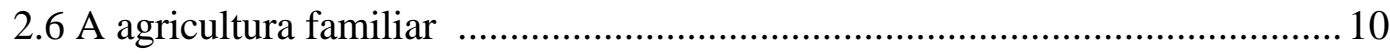

2.7 Importância dos SAFs para a Amazônia ........................................................... 11

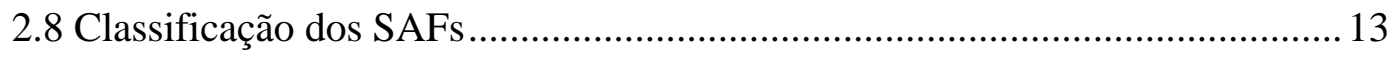

2.9 Cultivos agroflorestais praticados em regiões tropicais úmidas ..................... 16

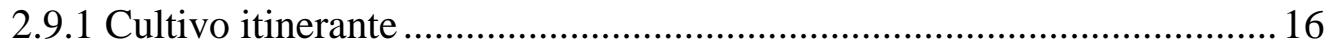

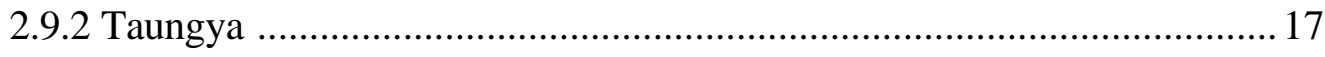

2.9.3 Cultivo e aléias (Alley cropping) .................................................... 18

2.9.4 Quintal caseiro (Homegarden) ........................................................... 19

$2.10 \mathrm{O}$ uso dos SAFs na Amazônia ............................................................... 20

2.11 Vantagens e desvantagens biológicas dos SAFs ................................... 21 


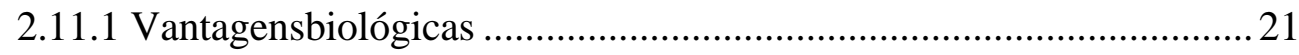

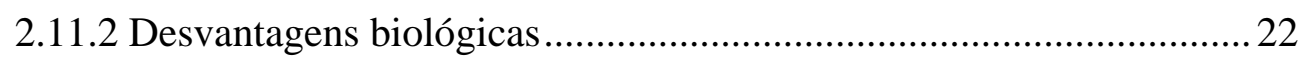

2.12 Programas agroflorestais nas instituições de pesquisas na Amazônia ............23

2.13 Espécies utilizadas nos sistemas agroflorestais .............................................25

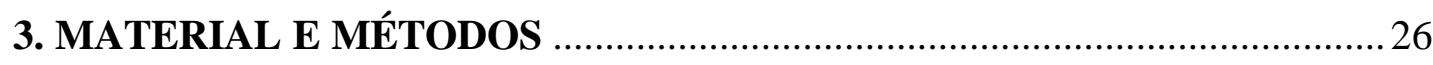

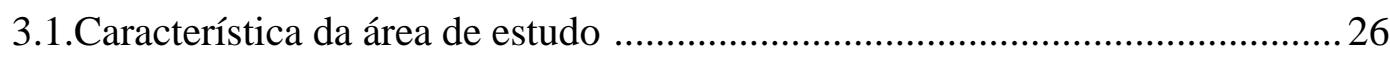

3.2 Descrição do Distrito Agropecuário da Suframa ………………………….......2 27

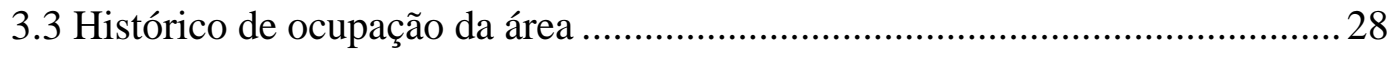

3.4 Geomorfologia do solo da região estudadas .................................................29

3.5 Descrição dos SAFs implantados no DAS ....................................................2

A) Sistema Agrossilvicultural AS1 Sistemas com base em palmeiras........ 30

B) Sistema Agrossilvicultural AS2 - baixos insumos (multiestrato)......... 31

C) Sistema Agossilvipastoril ASP1 - altos insumos...................... 32

D) Sistema Agossilviplstoril ASP2 - baixos insumos...................... 33

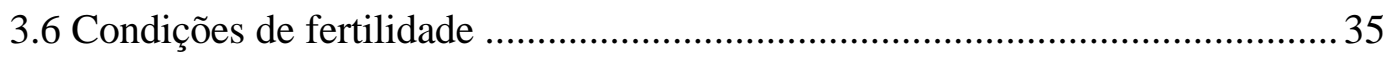

3.7 Proposta básica de avaliação econômica ...........................................................36

3.8 Definição dos fluxos de caixa e do método de avaliação ...................................36

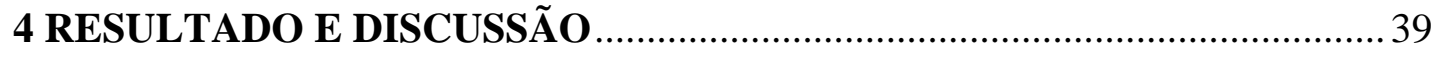

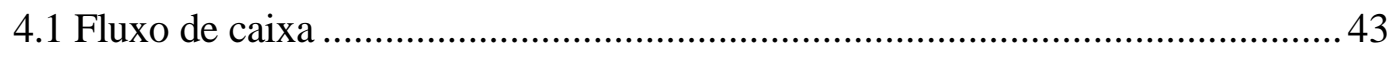

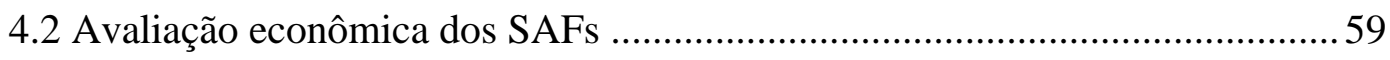

4.3 Viabilidade econômica dos modelos agroflorestais testados.............................62

4.4 Comparação entre sistemas consorciados e monocultivo.....................................63

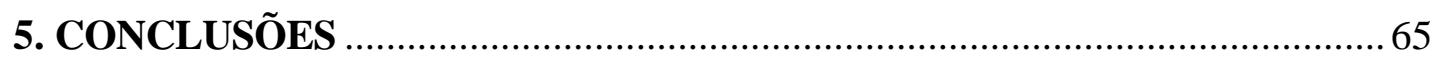

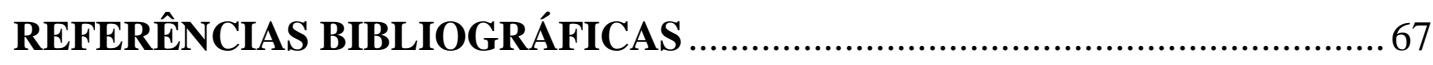




\section{LISTA DE FIGURAS}

$\begin{array}{lll}\text { Figura } & \text { Página }\end{array}$

1 Estação Experimental da EMBRAPA/CPAA,Manaus-AM. …………………………………….... 26

2 Localização da E.E.Embrapa no Distrito Agropecuário da Suframa - DAS. ..................................2

3 Perfil do histórico de ocupação do DAS/Manaus.........................................................................2

4 Representação dos blocos estudados na E.E.Embrapa/CPAA, DAS ……………............................ 30

5 Distribuição espacial dos componentes do AS1 ………………………………………………....... 31

6 Distribuição espacial dos componentes do AS2 - (multiestrato) . .................................................. 32

7 Distribuição espacial dos componentes do ASP 1 ………………………………………………...... 33

8 Distribuição espacial dos componentes do ASP1............................................................................ 34

9 Representação do fluxo da caixa do sistema AS1 com base em palmeiras...................................43

10 Representação do fluxo da caixa do sistema AS2 - (multiestrato)................................................. 47

11 Representação do fluxo da caixa do sistema ASP1 .......................................................................

12 Representação do fluxo da caixa do sistema ASP2 ..........................................................................

13 Desempenho econômico dos sistemas agroflorestais da E.E.Embrapa - CPAA,

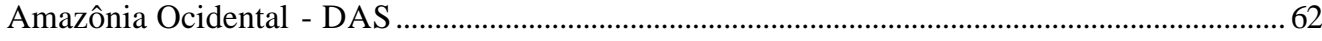




\section{LISTA DE TABELAS}

Tabela

Página

1 Espécies potenciais para diferentes cultivos associados 4

2 Características das espécies e seus respectivos usos nos sistemas agroflorestais na E.E.Embrapa/CPAA, Amazônia Ocidental. ...............................25

3 Análise químicas do solo onde os SAFs foram instalados..................................35

4 Composição, níveis de consorciação e ciclo de cultivo dos componentes do sistema agrossilvicultural com base em palmeiras (AS1)

5 Composição, níveis de consorciação e ciclo de cultivo dos componentes do sistema agrossilvicultural com base em palmeiras (AS2).

6 Composição, níveis de consorciação e ciclo de cultivo dos componentes do sistema agrossilvipastoril (ASP1).

7 Composição, níveis de consorciação e ciclo de cultivo dos componentes do sistema agrossilvipastoril (ASP2).

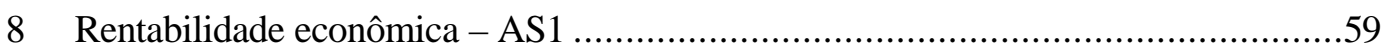

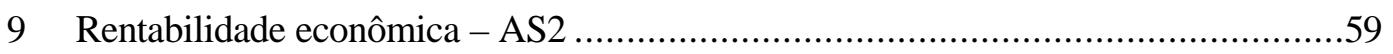

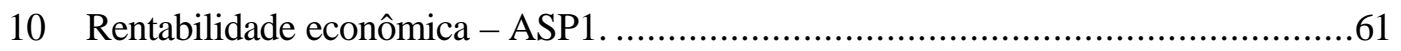

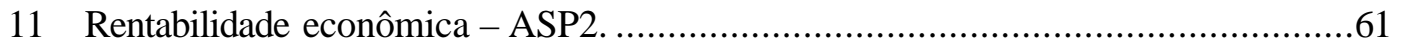

12 Comparação produtiva entre sistemas de monocultivo e sistemas consorciados. 


\title{
AVALIAÇÃO ECONÔMICA DE QUATRO MODELOS AGROFLORESTAIS EM ÁREAS DEGRADADAS POR PASTAGENS NA AMAZÔNIA OCIDENTAL
}

\author{
Autor: MÁRIO JORGE CAMPOS DOS SANTOS \\ Orientador: Prof. Dr. LUIZ CARLOS ESTRAVIZ RODRIGUEZ
}

\section{RESUMO}

O presente estudo teve como objetivo avaliar a viabilidade econômica de quatro sistemas agroflorestais em área com pastagem degradada na Amazônia Ocidental. A área escolhida para o desenvolvimento desta pesquisa está localizada na Estação Experimental da EMBRAPA/CPAA (Empresa Brasileira de Pesquisas Agropecuárias Centro de Pesquisas Agroflorestais da Amazônia Ocidental) no Distrito Agropecuário da SUFRAMA - DAS, Km 54 da BR-174 (Manaus-Boa Vista- Brasil), em áreas de terra firme.

Os modelos agroflorestais analisados foram implantados seguindo delineamento experimental em blocos casualizados, com 5 tratamentos, 3 repetições e a pastagem abandonada como testemunha, em parcelas de $3.000 \mathrm{~m}^{2}(60 \mathrm{~m} \times 50 \mathrm{~m})$, com uma área total de 4,5 ha. Os tratamentos foram distribuídos da seguinte forma: ASP-1 (Sistema Agrossilvipastoril - altos insumos); SP2 (Sistema Agrossilvipastoril - baixos insumos); AS1 (Sistema Agrossilvicultural - baixos insumos com palmeiras); AS2 (Sistema agrossilvicultural - baixos insumos multiestrato) e pastagem abandonada (testemunha). Houve aplicação de insumos para correção de acidez e fertilidade do solo. 
A avaliação econômica dos sistemas agroflorestais analisados baseou-se no cálculo do valor presente líquido dos respectivos fluxos de caixa constituídos a partir da presuposição que os mesmos podem ser repetidos perpetuamente. Os resultados obtidos, mostraram que os modelos agroflorestais utilizados são economicamente viáveis, indicando que este tipo de atividade pode contribuir para a regeneração de áreas com nível de degradação semelhante ao observado no estudo de caso e para a sobrevivência econômica dos agricultores da região. 


\title{
ECONOMIC EVALUATION OF FOUR AGROFORESTRY SYSTEMS MODELS IN DEGRADED PASTURES AREAS IN THE OCIDENTAL AMAZON
}

\author{
Author: MÁRIO JORGE CAMPOS DOS SANTOS \\ Adviser: Prof. LUIZ CARLOS ESTRAVIZ RODRIGUEZ
}

\section{SUMMARY}

Agroforestry systems have been considered to recover degraded areas, so as to increase the agricultural and forestry productivity and diminish the economic risk to the farmer. Four agroforestry models were introduced into a degraded pasture and abandoned areas located in one of the Experimental Station (Suframa-DAS) of the Embrapa/CPAA ( Empresa brasileira de pesquisas agropecuaria/ Centro de Pesquisas Agroflorestais da Amazônia Ocidental), at Km 54 BR-174 (Manaus-Boa Vista). This study was a randomized complete block design with 5 agroforestry models and three replicates for each model and an abandoned pasture area as the control. The parcel area measured $3,000 \mathrm{~m}^{2}(60 \mathrm{~m} \mathrm{X} \mathrm{50m)}$ for a total of 4.5 ha. Trataments were: ASP1 (Agrosilvipastoral systems - higt output); ASP2 (Agrosilvipastoral systems - low input); AS1 (Agrosilvicultural systems - low output with palmers tree); AS2 (Agrosilvicultural systems - low output multistrata). Fertilizers were to correct for the effects of soil acidity and soil fertility. Economic evaluations were based on the following economical criteria : Net Present Value and Land Expectation Value . Results showed that the agroforestry models were economically acceptable indicating that this kind of agroforestry activity generates income and could be used as an alternative way to recorver degraded areas in the Amazon. Agroforestry system AS2 produced the best results among the systems studied. All four systems were efficient at reestablishing the vegetative productivity. It produced agricultural benefits to the farmer and the utilized species play a important role 
in the land maintenance and protection against fire use and erosion. More research utilizing SAFs are required for this region to emphasize the economic benefits of the systems. 


\section{INTRODUÇÃO}

Grande parte da região amazônica não possui características fisiográficas e edafoclimáticas ideais para a prática agrícola convencional. Monoculturas extensivas e grandes projetos pecuários, em geral impactantes ao meio natural amazônico, também não estão ao alcance da unidade familiar típica amazônida. Na tentativa de reverter este cenário buscam-se alternativas e novas pesquisas que contribuam significativamente para o desenvolvimento sustentável dessa região, com custos sociais, econômicos e ambientais mínimos.

Os Sistemas Agroflorestais (SAFs) podem ser definidos como técnicas alternativas de uso da terra, que implicam na combinação de espécies florestais com culturas agrícolas, atividades pecuárias ou ambas. Essas combinações podem ser simultâneas ou escalonadas no tempo e espaço e de caráter temporário ou permanente (Smith et al., 1996; Swinkels \& Scherr, 1991; Anderson et al., 1991).

Os SAFs oferecem alternativas menos impactantes e podem auxiliar na reversão de processos de degradação, contribuindo para o aumento da biodiversidade animal e vegetal, além de satisfazer necessidades elementares e melhorar as condições de vida das populações rurais da região (Arima \& Uhl, 1996; Passos \& Couto, 1997; Rodigheri, 1997).

$\mathrm{Na}$ tentativa de testar alguns sistemas agroflorestais na Amazônia, a Embrapa/CPAA - Empresa Brasileira de Pesquisa Agropecuária /Centro de Pesquisa Agroflorestal da Amazônia Ocidental - instalou em 1991, no Distrito Agropecuário da Suframa (DAS) em Manaus, um experimento utilizando quatro sistemas agroflorestais em área degradada e/ou abandonada com diferentes históricos de uso. 
Este trabalho tem como objetivo avaliar economicamente esses quatro modelos agroflorestais como alternativas para a regeneração de áreas degradadas e como meios que proporcionem melhorias socioeconômicas para o agricultor da região amazônica.

\subsection{O impacto da atividade agrícola na Amazônia}

As florestas tropicais estão sendo destruídas a taxas alarmantes. Grande proporção da área desmatada na Amazônia brasileira é destinada à formação de pastagens e à agricultura de subsistência (Alvim, 1997; Homma et al., 1998; Miriti, 1998).

A atividade pecuária é considerada a atividade mais predadora do homem na região. A vida útil de produtividade dessas pastagens cultivadas na Amazônia é reduzida devido à implantação inadequada de espécies de gramíneas, à nãofertilização do solo e aos problemas de manejo dessas pastagens que degradam as propriedades físicas do solo (Serrão \& Homma, 1991).

A degradação dessas pastagens resultou da inadequação da tecnologia, que não se adaptou às condições da região, e da política de incentivos que financiava projetos pecuários com juros subsidiados, incentivando a ocupação da terra sem considerar os efeitos negativos do desmatamento (Serrão, 1990).

A agricultura de subsistência, em geral itinerante, também vem causando danos ao meio ambiente na Amazônia. É uma atividade de baixa produtividade dependente do uso intensivo de mão-de-obra familiar, com tempo de pousio reduzido e baseada no desmatamento e queimada freqüentes de novas áreas. Os pousios de longa duração não são atrativos aos produtores (Homma et al., 1998).

Esta agricultura itinerante concentrada em pequenas áreas também resulta em impactos ao meio ambiente, além de limitar os estoques naturais de nutrientes e de diversidade genética de plantas e animais (Preisinger, 1996, Gasparoto et al., 1990 e Young, 1990).

Serrão \& Toledo (1990) citam a existência na Amazônia brasileira de aproximadamente cinco milhões de hectares de pastagens degradadas e de outros cinco milhões de hectares de pastagens em regime de implantação, que no período de dez anos entrarão na categoria de pastagens degradadas. 
Nepstad et al. (1991) afirmam que a capacidade de regeneração da floresta diminui a cada mudança do uso da terra e o impacto dessas transformações, a longo prazo, resulta em áreas menos produtivas. Por conta dessas intervenções estima-se que existam cerca de $93.185 \mathrm{~km}^{2}$ de áreas desmatadas em diferentes estados de degradação e/ou abandonadas (MCT, 1999).

Atualmente um dos grandes desafios na Amazônia é transformar os recursos naturais degradados em áreas produtivas com potencial econômico sustentável, ajustando a melhoria na qualidade de vida humana à capacidade de suporte do ecossistema. (Avila, 1992; Goodland, 1995).

O contínuo aumento das necessidades humanas por alimentos e outros produtos agrícolas de importância industrial tem intensificado cada vez mais a questão do aumento de áreas de terras sob cultivo, especialmente em locais de baixa densidade demográfica. A produção integrada de espécies florestais com cultivos agrícolas e/ou pecuária tem sido mostrada como alternativa potencial para regiões tropicais. A adoção de SAFs levaria à formação de sistemas ecologicamente mais estáveis (Goodland, 1995; Young, 1990).

\subsection{0 problema}

Iniciativas oficiais de pesquisa resultaram na instalação de diversos estudos de introdução de SAFs na região amazônica. Sendo a pecuária a atividade agrícola que mais contribui para o aumento da área degradada ou abandonada nessa região, justificase a importância do experimento com SAFs do Centro de Pesquisas Agroflorestais da Amazônia Ocidental (CPAA) da Embrapa no Distrito Agropecuário da Suframa (DAS) em Manaus, AM.

As consorciações estudadas pelo CPAA neste experimento, além de viáveis tecnicamente, precisam ser economicamente justificadas. Estudos econômicos desta natureza inexistem para os ensaios implantados pelo CPAA. Acredita-se que a carência de uma metodologia apropriada justifique esse problema.

O presente trabalho contribui para a solução desse problema propondo um método de análise do desempenho econômico dos SAFs instalados pelo CPAA da Embrapa no DAS da Suframa em Manaus, AM. 


\subsection{Hipóteses de trabalho}

- Os sistemas agroflorestais são alternativas economicamente viáveis para a recuperação de pastagens em áreas de terra firme na Amazônia.

- As consorciações de espécies propostas nos SAFs conduzidos pela Embrapa/CPAA, no DAS (Distrito Agropecuário da Suframa) em Manaus apresentam resultados econômicos diferentes entre si.

- As espécies utilizadas nos SAFs estudados apresentam capacidade produtiva igual ou superior à respectiva alternativa de plantio em monocultivo.

\subsection{Objetivos gerais}

- Avaliar a viabilidade econômica dos sistemas agroflorestais em áreas de pastagem abandonadas e/ou degradadas na Amazônia Ocidental no Distrito Agropecuário da Suframa - DAS, em Manaus.

- Levantar através de revisão da literatura quais são os eventuais benefícios indiretos resultantes das consorciações propostas nos SAFs.

\subsection{Organização do trabalho}

O trabalho foi desenvolvido em seis partes. A primeira parte resume o problema, as hipóteses e os objetivos deste estudo.

Em seguida, é feita uma revisão sobre a dimensão da degradação da Amazônia causada pela atividade pecuária e agrícola na região.

Na terceira parte, os SAFs são apresentados como soluções potenciais para a recuperação das áreas degradadas e/ou abandonadas pelo uso das pastagens e como sistemas potencialmente viáveis para o sustento de famílias rurais na região.

A apresentação do delineamento experimental usado pela Embrapa-CPAA para implantação dos SAFs, os dados coletados e o critério proposto para avaliação dos sistemas se encontram na seção "Material e Métodos". A seção "Resultados e Discussão" apresenta os fluxos de caixa e tabelas com os resultados das análises para cada sistema. 
Na última seção são apresentadas as conclusões e algumas sugestões para o desenvolvimento futuro de novos métodos de avaliação econômica de SAFs na Amazônia. 


\section{REVISÃO DE LITERATURA}

\subsection{Degradação da Amazônia causada pela atividade agropecuária}

A Amazônia brasileira é um espaço continental, abrangendo $5.217 .423 \mathrm{~km}^{2}$, cerca de $61 \%$ do território nacional, com uma população recenseada em torno de 17,6 milhões de habitantes - incluindo o Estado de Mato Grosso e parte do Maranhão que compõem a Amazônia Legal - ou 11,8\% do total nacional. A essa população, deve-se acrescer um contingente indígena de aproximadamente 172.000 pessoas, cerca de $80 \%$ do existente no País, distribuído em 200 grupos étnicos. Embora a densidade demográfica da Amazônia esteja em torno de 3,37 hab/km², sua população supera, em números absolutos, a de vários países do mundo (MCT, 1999).

Nas últimas décadas, essa região tão rica e, ao mesmo tempo, tão distante da realidade nacional, passou por uma intensa e acelerada integração ao padrão de crescimento econômico brasileiro na qualidade de reserva de recursos naturais para a industrialização emergente e como fronteira para grandes frentes migratórias de ocupação do território (Meireles, 1993: Carvalho, 1998).

Diferentes ondas de ocupação foram provocando a reorganização do espaço regional e redefinindo a estrutura produtiva da Amazônia. Apesar de vários anos de degradação, a Amazônia ainda conserva as principais características do seu patrimônio natural e a essência da sua riqueza biológica (Zimmer, 1994).

A dimensão territorial da Amazônia brasileira lhe confere um status de quasecontinente, representando grande potencial ecológico, econômico e político, de importância estratégica nacional. Ao contrário das outras florestas tropicais úmidas do planeta, a Floresta Amazônica é um grande maciço concentrado no território brasileiro, administrado, portanto, por um mesmo Estado nacional (Oliveira \& Vosti, 1997).

Com cerca de um terço das florestas tropicais úmidas da Terra, a Amazônia brasileira contém quase 300 milhões de hectares de floresta densa e 240 milhões de 
hectares de floresta aberta, com um estoque total de madeiras comercializáveis na ordem de 45 bilhões de metros cúbicos de madeira em pé, matéria-prima importante para os setores madeireiro, moveleiro, papel-celulose, químico e energético (Toniollo \& Uhl, 1996).

\subsection{Histórico das atividades do uso das Pastagens}

As pastagens nativas, maior fonte de alimentos para os herbívoros domésticos, ainda ocupam cerca de 50\% das áreas de pastagens do Brasil (Zimmer, 1994). Já as pastagens cultivadas vêm ocupando áreas cada vez mais extensas, passando de 30 milhões de hectares, em 1970, para 105 milhões de hectares em 1995 (dados estimados), o que representa um incremento de área plantada em 25 anos de 250\%. Dos 117 milhões de hectares de pastagens (nativa 75 e cultivada 42) do Brasil Central (cerrado), cerca de 34 milhões de hectares foram formadas há aproximadamente 20 anos e encontram-se em diferentes estágios de degradação (Zimmer \& Euclides Filho, 1997; Oliveira et. al., 1995).

O aumento da área cultivada com pastagens, nos últimos 25 anos, resultou principalmente da necessidade de aumentar a produtividade da pecuária brasileira em função da demanda crescente por produtos de origem animal (Zimmer \& Euclides Filho, 1997; Nascimento Junior, 1998).

Pastagens formadas sem nenhum conhecimento agronômico e animais tratados sem manejo adequado podem ser produtivos nos primeiros anos após o seu estabelecimento, mas perdem a produtividade logo em seguida, conforme relatado por Andrade \& Leite (1988) e Andrade (1986), na região do cerrado e Serrão et al. (1982), Veiga \& Falesi (1986) e Veiga \& Serrão (1987), na região amazônica .

\subsection{Causas da degradação por pastagens}

Várias são as definições encontradas na literatura para "degradação de pastagens". Macedo (1993) e Macedo \& Zimmer (1993) a definem como o processo evolutivo da perda de vigor, de produtividade, da capacidade de recuperação natural das pastagens para sustentar os níveis de produção e qualidade exigidos pelos animais,assim como o de superar os efeitos nocivos de pragas, doenças e invasoras, culminando com a 
degradação avançada dos recursos naturais em razão de manejos inadequados. Carvalho (1993) se refere à degradação das pastagens como sendo a redução da produção de forragem e também do seu valor nutritivo, mesmo em épocas favoráveis ao crescimento.

Spain \& Gualdron (1991) definem a degradação como sendo a diminuição considerável na produtividade potencial para as condições edafoclimáticas e bióticas a que está submetida. Para Meirelles (1993), a degradação é crucial quando a produção de forragem é insuficiente para manter determinado número de animais no pasto e por um certo período.

Pelas definições acima expostas, o conceito de degradação é dinâmico e pode ser caracterizado por um conjunto de fatores que agem de maneira associada, sendo que a degradação pode ser reduzida ou agravada pelas práticas de manejo.

\subsection{Processo de degradação de pastagens}

Macedo (1995) considera a degradação das pastagens utilizando as seguintes etapas: implantação e estabelecimento das pastagens, utilização das pastagens (ação climática e biótica, práticas culturais e de manejo) e queda da produtividade - efeito na capacidade de suporte; queda na qualidade nutricional. Ele conclui que o acompanhamento da capacidade de suporte permite antecipar etapas mais graves no processo de degradação, principalmente quando os recursos naturais já começam a se deteriorar.

Nascimento Júnior et al. (1994) comentam que o manejo da pastagem visa preservar o equilíbrio entre o rendimento e a qualidade da forragem produzida e a manutenção da composição desejada para o pasto, com similaridade na produção ótima por animal e por área. Assim, o conhecimento das inter-relações dos componentes envolvidos é de vital importância no controle e na manipulação dos sistemas de pastejo.

Geralmente, os fatores que causam a degradação das pastagens estão associados ao manejo das mesmas. Contudo, falhas de natureza técnica durante o processo de semeadura e estabelecimento podem concorrer para tal degradação (Dias Filho, 1998; Nascimento Júnior et al., 1994; Carvalho, 1993 e Spain \& Gualdron, 1991). 


\subsection{A agricultura na Amazônia}

A análise da agricultura e pecuária na Amazônia é muito complexa devido à diversidade de ambientes, de uso da terra e de situações sociais (Nascimento Júnior et al., 1994). A agropecuária na Amazônia se divide em dois ecossistemas básicos: 'Terra Firme", as áreas não atingidas pelas inundações dos rios e "Várzea", áreas submetidas às enchentes dos rios (Flores et.al, 1995; Serrão et al., 1998).

$\mathrm{Na}$ terra firme, pratica-se a agricultura itinerante, método tradicional de rotação do cultivo praticado por índios e caboclos utilizando culturas anuais, a pecuária bovina, as culturas perenes e hortaliças (Fernandes et. Al, 1995; Costa, 1998a).

$\mathrm{Na}$ várzea, são desenvolvidas as culturas anuais como o arroz, a hortaliça, as culturas de fibras e a criação de bovinos e bubalinos em pequenas propriedades, praticadas pelas populações ribeirinhas, (Costa, 1998b).

O desenvolvimento da agricultura na região passou por diversas fases, determinadas pelas políticas governamentais, que foram concebidas desde a década de 30 buscando integrá-la à dinâmica econômica e à política nacional (Fearnside, 1990).

A região foi percebida historicamente como um "vazio demográfico" e uma área de grande estagnação econômica. Até o início dos anos 50, as políticas públicas privilegiavam os setores comerciais tradicionais de produção extrativista como a castanhado-brasil e a borracha (Serrão et al., 1998).

Nas décadas de 60 e 70, os Planos de Desenvolvimento da Amazônia foram direcionados para favorecer a implantação dos "Grandes Projetos", através de subsídios e incentivos fiscais oferecido pelo governo federal e do acesso facilitado às terras para grandes grupos privados, que causaram profundas transformações ao meio ambiente (Fearnside, 1998, 1997, 1990; Projeto Cut/Contag, 1998; Serrão et al.,1998).

A pecuária em larga escala foi introduzida na região amazônica a partir do final da década de 60, também patrocinada pelos incentivos governamentais através da Superintendência do Desenvolvimento da Amazônia (Sudam) e da Superintendência da Zona Franca de Manaus (Suframa), que privilegiaram os empreendimentos pecuários com isenção do imposto de renda e financiamentos diretos para formação de pastagens e desmatamentos (Costa, 1998b). 
No final dos anos 80, a agricultura itine rante passa por uma crise brutal de falta de recursos para financiar a produção (Costa, 1998b). Com isto, amplia-se o debate sobre a possibilidade de outro modelo de desenvolvimento para região.

Foram, então, desenvolvidos estudos no sentido de mostrar que a produção agrícola familiar é um ator com forte potencial para o desenvolvimento sustentável na Amazônia (Projeto Cut/Contag, 1998).

O quadro atual tem mostrado que apesar das experiências existentes de agricultura sustentável na Amazônia, por não possuir uma estrutura consolidada, existem possibilidades de um desenvolvimento agrícola com elevado grau baseado na agricultura diversificada e adaptada às condições tropicais (Serrão et al. 1998).

É necessário considerar a diversidade de situações e planejar uma combinação certa de instrumentos voltados para a produção agrícola, para a preservação ambiental e às condições socioeconômicas de cada grupo de produtores (Kitamura, 1994).

\subsection{Agricultura Familiar}

A agricultura migratória é provavelmente o sistema de uso da terra mais importante na Amazônia, não só do ponto de vista econômico. Esta atividade é responsável por pelo menos $80 \%$ da produção de alimentos na região (Kitamura, 1994).

Essa prática é desenvolvida e praticada em quase toda a região por, pelo menos, 600.000 pequenos agricultores, produzindo principalmente feijão, mandioca, arroz, milho, malva, juta, frutas e algodão entre outros produtos (Idam, 1997; Homma, 1998).

O problema maior que se apresenta no momento em termos de políticas públicas para as populações rurais da Amazônia relaciona-se às dúvidas sobre a viabilidade da agricultura de subsistência, em especial nas áreas de fronteira (Homma, 1998; Kitamura, 1994). Apesar da sua importância na economia regional, a agricultura migratória tende a entrar em declínio, com a diminuição da expansão da fronteira agrícola devido às restrições aos desmatamentos (Walker, 1998).

Vários autores têm observado que houve mudanças evolutivas nos sistemas de produção familiar que dependem de alternativas mais lucrativas ou decorrentes de necessidades econômicas (Walker, 1998). 
Kitamura (1994) cita que as decisões do uso da terra pelos agricultores na Amazônia são afetadas, entre outros fatores, pela estrutura fundiária e pelos aspectos relacionados à integração a mercado, tecnologia, conhecimento produtivo, políticas de crédito e ao mercado de trabalho.

Os processos produtivos praticados por esses produtores têm mostrado a possibilidade de sua sustentabilidade econômica, social e ecológica, porém o processo de acumulação nem sempre acontece, permanecendo os mesmos níveis de subsistência (Walker, 1998).

De uma forma geral, o aumento no estoque de mão-de-obra familiar facilita o estabelecimento de cultivos perenes que são onerosos em termos de mão-de-obra (Toniolo \& Uhl, 1996).

O desenvolvimento da pecuária e a implantação de um sistema agroflorestal (culturas perenes consorciadas com culturas anuais), constitui uma decisão de investimento cujos retornos não vêm a curto prazo para as unidades familiares (Walker et al., 1993).

\subsection{A importância dos SAFs para a região amazônica}

Os sistemas agroflorestais têm como principal característica a inclusão de espécies arbóreas em associações com culturas agrícolas, combinando plantas de ciclo anual, plantas perenes, semiperenes de florestas e/ou criação animal simultaneamente ou em seqüência temporal adequadas aos padrões culturais da população local (Nair, 1989; Vilas Boas, 1991; Dubois, 1996; Current, Lutz \& Scherr, 1995a)

Os sistemas agroflorestais têm sido recomendados como uma solução e/ou alternativa para recuperação de áreas degradadas, com potencial de gerar maiores produtividades agrícola, florestal e pecuária, e como mecanismo redutor de risco para o agricultor (Vilas Boas, 1991; Montagnine et al., 1992).

Para Farrel \& Altieri (1987), os sistemas agroflorestais devem incorporar cinco características básicas:

1) Estrutural: combinação de árvores, culturas anuais e animais no tempo e/ou espaço; 
2) Sustentabilidade: usando sistemas naturais como modelo, busca a otimização dos efeitos benéficos da interação entre espécies lenhosas, culturais e animais, mantendo a produtividade a longo prazo, sem causar dano ao recurso base;

3) Aumento da Produtividade: através da utilização racional das relações de complemento entre os diversos componentes, na melhora das condições promotoras do crescimento de plantas e do uso mais eficiente dos recursos naturais (espaço, água, solo e luz);

4) Adaptabilidade socioeconômica e cultural: esses sistemas se adaptam a uma variedade de situações socioeconômicos, podendo ser aplicados a todos os tipos de propriedades rurais; e

5) Aceitabilidade: este importante atributo subentende que a agrofloresta tenha sido aceita pela comunidade local. E que qualquer implementação num sistema agroflorestal deva conter os melhoramentos e as sugestões da comunidade local. 


\subsection{Classificação dos SAFs}

O principal propósito da classificação dos SAFs é fornecer subsídios práticos para a síntese e análise de informação acerca de sistemas existentes e o desenvolvimento de novos e promissores sistemas (Passos \& Couto, 1997).

A classificação dos SAFs se baseia nos critérios de arranjo espacial e temporal, na importância e no papel dos componentes, no planejamento da produção ou na produção do sistema e suas características socioeconômicas (Nair, 1985b, 1993).

- Base estrutural: refere-se à composição dos arranjos espaciais do componente lenhoso (árvore), estratificação vertical, bem como o arranjo temporal dos diferentes componentes;

- Base funcional: refere-se à função principal no sistema, usualmente devido aos componentes lenhosos (podendo ser de natureza protecionista ou de serviço, por exemplo: quebra-vento, conservação de solo);

- Base socioeconômica: refere-se ao nível de manejo "inputs" (altos, baixos insumos) ou intensidade ou escala de manejo e objetivos comerciais (subsistência, comercial, intermediário);

- Base ecológica: refere-se às condições ambientais e ecológicas dos sistemas, com base na suposição que certos tipos de sistemas podem ser mais apropriados para determinadas cond ições ecológicas (SAFs para zonas áridas e semi-áridas, tropicais de baixada ou terra firme).

Nair (1993) comenta que a complexidade da classificação dos SAFs pode ser reduzida se os aspectos estruturais e funcionais tais como socioeconômicos e agroecoló gicos/ambientais forem considerados como base para agrupar os sistemas.

Esta classificação poderá ser subdividida:

De acordo com a natureza dos componentes: existem três conjuntos de elementos que são manejados pelo agricultor, que são: as árvores (espécies lenhosas perenes), as culturas anuais (agronômicas, incluindo espécies para pastagem) e o componente animal. Três importantes categorias são reconhecidas nesta classificação, que são: sistemas agrossilviculturais (culturas, incluindo arbustivas/trepadoras) e árvores; sistemas 
agrossilvipastoris(culturas, pastagens/animais e árvores); e silvipastoris (pastagem/animais e árvores).

As espécies herbáceas são também incluídas na maioria dos SAFs, sendo exceções a apicultura com árvores, mistura de cultivos perenes tais como café e seringueira, ou café, cacau e chá sob sombra de árvores, os quais são classificados como "outros".

De acordo com o arranjo dos componentes: o arranjo de plantas em combinações de espécies múltiplas envolve as dimensões de espaço e tempo. $\mathrm{O}$ arranjo espacial de plantas varia desde sistemas mistos adensados (como os quintais caseiros "homegardens") até os sistemas de baixa densidade (como os agrossilvipastoris). Além do mais, os sistemas podem ser zonais ou em faixas de diferentes larguras, com variações como os arranjos microzonais (como os sistemas em ruas ou fileiras alternadas), ou

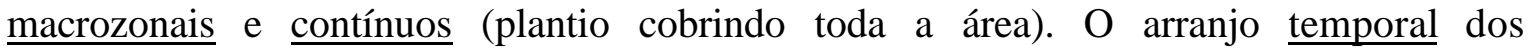
componentes pode também variar de forma. Vários sistemas silvipastoris se enquadram nesta categoria, pois envolvem rotação de cultivo de gramíneas que se alteram com o plantio de árvores (Huxley, 1983).

A produção e proteção são dois atributos fundamentais de todos os sistemas agroflorestais. Portanto, nesta categoria são relacionados os sistemas produtivos (com base no suprimento de demandas de alimento, forragem, materiais de construção, energia, etc.) e os protecionistas (com base em práticas agroflorestais que contribuem para aumentar ou manter a sustentabilidade do sistema).

Usando critérios socioeconômicos tais como escala de produção e nível tecnológico de insumos e manejo, Lindgren (1982) agrupou os SAFs em comercial, intermediário e subsistencial.

O termo comercial é usado quando o alvo do sistema é a produção visando o mercado. Neste sistema, a escala usualmente varia de média a larga. Por exemplo, plantios de culturas perenes tais como coco, borracha e dendê, os quais são explorados para a produção de alimentos, podem ter uma integração de pastagem e animais (Huxley, 1983).

São incluídos nesta modalidade a produção comercial de espécies tolerantes à sombra como café, chá e cacau plantadas em combinação com árvores de sombra, bem como os sistemas rotacionais de produções de alimento/madeira, nos quais a fase de 
produção de alimento é usada para garantir a implantação de espécies perenes (Canto et al., 1991).

Sena Gomes (1992) lista várias modalidades de SAFs comerciais desenvolvidas no sul da Bahia, envolvendo os produtos borracha e dendê, a produção de alimentos e, em algumas combinações, o uso de espécies na produção de condimentos. $\mathrm{O}$ autor exemplifica também o caso da produção de cacau em associações com espécies arbóreas da Mata Atlântica utilizadas no sombreamento do cacaueiro.

Similarmente, Canto et al. (1991) também mencionam a utilização desta modalidade de SAF comercial, com as devidas variações, objetivando atender às demandas de alimentos para os mercados regionais na Amazônia.

Os sistemas agroflorestais intermediários são aqueles situados entre os comerciais e os de subsistência em termos de escala de produção e manejo. Em geral, são praticados em pequenas a médias propriedades e lidam com a produção de cultivos de subsistência destinados à alimentação familiar e, ao mesmo tempo, com "cash crops" para atender às necessidades imediatas.

Os SAFs no grupo de subsistência são aqueles caracterizados pelo consumo de quase todos os produtos obtidos na propriedade pela família. Em geral, são empregados onde o uso de terra é direcionado para satisfazer as necessidades básicas e são manejados pela família (Bandy et al., 1994).

A maioria dos SAFs praticados em várias partes dos países em desenvolvimento cai nesta categoria. $\mathrm{O}$ cultivo tradicional da agricultura itinerante, a mais usada forma de cultivo do solo nos trópicos (ocupando cerca de 30\% dos solos aráveis do mundo), também chamada de agricultura migratória, muito popular na Amazônia brasileira, enquadra-se nesta categoria (Canto et al., 1991).

Van Leeuwen \& Gomes (1999) citam outro exemplo de SAF de subsistência, quintal caseiro ou "homegarden" (árvores, arbustos, trepadeiras e herbáceas cultivadas em quintais ou próximas a residências e manejadas pela própria família). 


\subsection{Cultivos agroflorestais praticados em regiões tropicais úmidas}

Esta seção contém uma descrição sumária dos principais SAFs praticados pelos produtores das áreas tropicais úmidas brasileiras, principalmente dos estados amazônicos e do sul da Bahia. Entre os mais importantes SAFs, incluem-se os cultivos: itinerantes, "taungya", quintal caseiro "homegardens", aléias "alley cropping", combinação de perenes e silvipastoris (Nair,1985a).

\subsubsection{Cultivo itinerante}

O "cultivo itinerante", conhecido também como agricultura migratória "shifting cultivation" ou agricultura de derruba e queima, refere-se ao sistema de uso do solo no qual a cobertura vegetal é derrubada e queimada, feito o cultivo com espécies alimentícias por alguns anos e, então, a área é abandonada para regeneração (pousio) com vegetação natural por alguns anos (Huxley, 1983; Nair, 1987; Nair. et al.,1977).

O sistema varia de acordo com as condições ecológicas locais. Em muitas áreas, a prática da derruba da floresta acontece no período seco (ou nos meses menos chuvosos), a queima é realizada antes das primeiras chuvas e o plantio de espécies como milho, feijão, mandioca e bananas é realizado aproveitando as cinzas da queimada e o material em decomposição.

As espécies são plantadas na forma de intercultivos irregulares e na mesma gleba por dois a três anos. Já o período de pous io pode variar de cinco a 20 anos dependendo da cultura utilizada, das condições locais e da densidade populacional.

Este sistema tradicional de cultivo dos solos é talvez o mais importante de todos os SAFs utilizados no mundo tropical. Estimativas da FAO (1982) mostram que aproximadamente 360 milhões de ha (ou cerca de 30\% dos solos aráveis do globo) estavam sendo explorados com o cultivo itinerante e envolvem o sustento de cerca de 250 milhões de pessoas.

Bandy et al. (1994) comentam que o sistema oferece uma base para a agricultura de subsistência, para a manutenção dos valores culturais e para a estabilidade social das pessoas que vivem em regiões de floresta úmida e de baixa densidade populacional. Consideram também que a África e a América Latina são as duas regiões dos trópicos que mais utilizam esse sistema de cultivo. 
Nestas áreas tropicais, com baixa densidade demográfica, onde os colonos têm muitas áreas à disposição para o cultivo, em geral, o sistema é estável e ecologicamente balanceado. Entretanto, com o aumento da pressão populacional, em muitas áreas, o período de pousio é drasticamente reduzido e o sistema torna-se degenerado, resultando em sérios danos causados por erosão dos solos, queda na fertilidade e produtividade do solo (Nair, 1993).

Por estes motivos é que se vem tentando a introdução de algumas modificações nos sistemas existentes, a exemplo do que se chama de pousio melhorado e pousio com árvores ou pousio plantado, cujo objeto é a manutenção e/ou melhoria da fertilidade do solo. Bandy et al. (1994) esclarecem que o sucesso do cultivo itinerante está baseado no ciclo de nutrientes e na eliminação das pragas durante o período de pousio.

\subsubsection{Taungya}

É também considerado um dos sistemas agroflorestais mais importantes porque envolve grande variedade de combinações de espécies, modalidades e adaptações às condições regionais.

Nair (1993) revisando o assunto, esclarece que inicialmente "taungya" era um termo local usado para designar cultivo itinerante e foi subseqüentemente utilizado para descrever um método de reflorestamento (King, 1968; Okigbo, 1985 e Beer et al., 1994).

Essencialmente, o método consiste em cultivar espécies alimentícias anuais conjuntamente com espécies florestais durante os primeiros anos de estabelecimento (Beer et al., 1994).

Este método se tornou muito atrativo a partir do programa de reflorestamento com teca (Tectona grandis) na Índia, onde o governo fomentava e permitia que os colonos plantassem cultivos de subsistência entre as árvores do reflorestamento (Beer et al., 1994).

O sistema se tornou tão popular que recebeu diferentes denominações em vários países tais como: "chana" (Sri Lanka), "taila e tucle" em diferentes partes da Índia , "shamba" (leste da África), "parcelera" (Porto Rico) e consorciação e parceria (Brasil).

Muitos plantios de espécies lenhosas perenes, tanto em grandes como em pequenas propriedades do sul da Bahia e de vários estados amazônicos, tiveram início através de um sistema semelhante ao "taungya". Mas, a modalidade de exploração das 
culturas alimentares não foi o da parceria e sim na base de contratação de mão-de-obra pelo proprietário. Desta forma, o sistema não seguiu um dos objetivos do processo que é o de promover melhorias sociais para os parceiros (Ruthemberg, 1980; Sena Gomes, 1992).

O sistema oferece algumas vantagens em relação a um reflorestamento puro, tais como: a) o manejo e o ganho agrícola reduzem ou pagam os custos do estabelecimento de árvores; b) consegue-se melhores taxas de crescimento e sobrevivência das árvores devido ao manejo agrícola (limpeza, aplicação de fertilizantes, etc); c) maior disponibilidade de nitrogênio para as árvores quando o cultivo é combinado a leguminosas (Broonkird et al., 1984).

Quanto às desvantagens do sistema, é possível enumerar alguns fatores principais como: a) efeitos alelopáticos das árvores nas culturas; b) danos às raízes durante a colheita de raízes ou tubérculos; c) em relação a pragas e doenças, a associação pode ser altamente prejudicial e instável se as culturas e as árvores são susceptíveis ao mesmo tipo de patógenos (Nair, 1993).

\subsubsection{Cultivo em aléias (Alley cropping)}

Este tipo de cultivo foi desenvolvido na Nigéria e poder ser conceituado como um sistema agroflorestal simultâneo. Consiste na consorciação de árvores e/ou arbustos, geralmente fixadores de nitrogênio, intercalados em faixas com culturas anuais (Broonkird et al., 1984).

As árvores e/ou arbustos sofrem podas periodicamente para impedir que produzam sombras às culturas, sendo que os resíduos da poda são utilizados como adubo verde na melhoria da fertilidade do solo e/ou como forragem de alta qualidade.

Um dos benefícios deste sistema é o controle de plantas daninhas através da competição por espaço, luz, nutrientes e água.

O cultivo em aléias foi inspirado nas práticas dirigidas à recuperação de áreas de pousio mediante o uso de coberturas verdes. Baseia-se no princípio de que é possível obter um uso produtivo e sustentável da terra quando os métodos de conservação e reabilitação são introduzidos antes de que ocorra degradação séria dos recursos (Sena Gomes, 1992).

Pode ser adotado como um sistema de agricultura migratória melhorado e possui as seguintes vantagens: 
a) as práticas de cultivo e pousio são realizadas simultaneamente;

b) obtém-se um maior período de cultivo e um uso mais intenso da terra;

c) consegue-se uma regeneração mais efetiva da fertilidade do solo utilizando espécies mais eficientes (Kang \& Wilson, 1987).

\subsubsection{Quintal caseiro (Homegarden)}

Ruthemberg (1980) e Price (1989) definem este sistema como um complexo de plantas perenes ou semiperenes, utilizado por pequenos agricultores com uma superfície na ordem de um hectare e que encontram-se próximos às suas casas.

Entretanto, Nair (1987) inclui os animais como elementos complementares em sua definição e descreve os "homegarden" como a associação densa de plantas, sem nenhuma organização aparente em sua plantação e que, além disto, apresentam múltiplos estratos e espécies.

Observourse neste sistema uma alta intensidade de ocupação do solo, que se caracteriza por uma alta diversidade de espécies de diferentes idades, formando múltiplos estratos em competição por água, luz e nutrientes (Van Leeuwen \& Gomes, 1999).

Esta alta diversidade gera fatores positivos quanto à reciclagem de nutrientes, proteção do solo e, simultaneamente, permite ao agricultor obter uma produção quase que contínua de alimentos e gerar renda durante o ano (Ruthemberg, 1980).

Víquez et al. (1994) citam que esses sistemas simulam a floresta natural e existe a possibilidade de melhorar a produtividade mediante uma redistribuição do espaço ou mudança do uso da área.

Contudo, algumas espécies possuem uma produtividade muito baixa ou sem nenhuma importância do ponto de vista econômico, apesar de poderem ser bastante úteis para o agricultor devido às suas funções medicinais, estéticas e/ou até mesmo culturais (Van Leeuwen \& Gomes, 1999). 


\subsection{O uso dos SAFs na Amazônia}

Os sistemas agroflorestais na Amazônia têm origem em longa tradição indígena, modificando-se com a colonização e a evolução dos costumes. A agricultura cabocla, baseada na roça, utiliza sistemas tradicionais abertos ao mercado, combinando culturas anuais com fruteiras perenes (Canto et al., 1992; Almeida et al., 1995; Fernandes, 1986).

Na Amazônia, o termo "agrofloresta" surgiu no fim da década de setenta e tornou-se popular no início da década de noventa (Van Leeuwen et al., 1994; Current et al., 1995b; Dubois, 1996; Canto et al., 1997).

Em geral, os sistemas tradicionais na Amazônia são conhecidos como quintais caseiros e são suficientemente produtivos para satisfazer as necessidades crescentes da população. Por esta razão, esses sistemas são praticados por comunidades locais onde a mesma área de terra produz durante dezenas de anos (Current et al., 1995b).

O sistema tradicional não sofre interferência ou estímulo dos serviços oficiais de agricultura, tornando-se necessário desenvolver e melhorar técnicas mais apropriadas para uma maior produtividade (Oliveira \& Vosti, 1997).

Os sistemas agroflorestais podem oferecer alternativas para o uso dos recursos naturais que aumentem ou pelo menos mantenham a produtividade da terra sem causar degradação (Montagnine, 1992; Almeida et al., 1995; Oliveira \& Vosti, 1997; Van Leeuwen \& Gomes, 1999).

A importância dos sistemas agroflorestais em particular determina a dinâmica de alguns processos ecológicos importantes e as expectativas econômicas dos agricultores, além da necessidade de apresentar-se como uma opção aceitável para as famílias rurais (Montagnine, 1992).

As condições econômicas são elementos básicos para a tomada de decisões nas análises das alternativas agroflorestais. É necessário que a importância e a distribuição regional desses sistemas sejam definidas no contexto político e do desenvolvimento para a Amazônia (Van Leeuwen \& Gomes, 1999).

Qualquer alternativa que venha a ser desenvolvida para o bem-estar do produtor deve adequar-se às suas limitações e necessidades sociais e econômicas (Reiche, 1983; Vilas Boas, 1991; Fearnside, 1996; Oliveira \& Vosti, 1997). 


\subsection{Vantagens e desvantagens biológicas dos SAFs}

É certo que a prática dos SAFs utilizada nas mais diversas regiões do planeta, em milhões de propriedades ao longo dos tempos, permite visualizar as vantagens e desvantagens de tais sistemas em comparação a outras atividades de uso da terra. Entretanto, é indispensável que a ciência que pratica esses sistemas possa comprovar a viabilidade de suas vantagens (Montagnine, 1992).

Vilas Boas (1991) comenta que os sistemas agroflorestais devem funcionar como uma ferramenta fundamental para alcançar o objetivo do rendimento sustentado permanente, sobretudo em regiões onde a fragilidade ambiental é um grande obstáculo para o desenvolvimento rural.

Couto et al. (1992), Current \& Lutz (1990) e Scherr (1995) citam que os sistemas agroflorestais podem contribuir para a viabilidade econômica de pequenos produtores e melhoria da qualidade de vida das comunidades através da diversificação da produção, diminuindo o riscos de flutuações de preços no mercado e ampliando alternativas alimentares de subsistência.

\subsubsection{Vantagens Biológicas}

a) Consorciação de espécies com diferentes exigências de luz, água e nutrientes, torna possível o uso mais eficiente nos fatores de produção, reduzindo o risco econômico da inversão.

b) Propriedades físicas, químicas e biológicas do solo: Glover \& Beer (1986) e Connor (1983) citam que espécies perenes promovem ciclagem de nutrientes desde as camadas mais profundas do solo para as camadas superficiais, via translocação de nutrientes.

c) Controle de erosão do solo: os sistemas agroflorestais que contam em sua consorciação com espécies que ocupam diferentes extratos de copa podem reduzir o impacto das chuvas, proporcionando refúgio contra a radiação solar, as altas temperaturas, ventos e um risco futuro de erosão (Budowvisk, 1991). 
d) Diminuição de variáveis microclimáticas: nos sistemas agroflorestais, o dossel das espécies perenes assume o papel de proteger o solo da radiação solar direta no período diurno e impedir que haja perda de energia à noite, diminuindo a amplitude de variação de temperatura e umidade local.

e) Uso apropriado do sombreamento: algumas culturas como cacau, cupuaçu, café e palmito são beneficiadas com o sombreamento. Isso ocorre em locais onde as condições do solo não são adequadas, quando a pluviosidade é muito grande ou quando a temperatura é bastante elevada (Broonkird et al., 1984).

f) Uso da espécie adequada no sistema: as espécies introduzidas nos sistemas agroflorestais podem controlar ou reduzir o desenvolvimento da toxidez do solo existente bem como da acidificação e salinificação.

\subsubsection{Desvantagens Biológicas}

a) Competitividade entre componentes vegetais: entre as espécies perenes e culturas anuais, ocorre competição por nutrientes, espaço de crescimento, luz e umidade, podendo ocorrer a redução de produtos alimentares. Este conflito pode ser minimizado pela escolha de espécies arbóreas com sistemas radiculares mais profundos e com copas menos densas permitindo assim maior passagem da radiação solar.

b) Prejuízos causados pelo componente animal : quando se utiliza sistemas agrossilvipastoris que incluem plantas agrícolas, espécies arbóreas e animais, há uma tendência à interação negativa entre seus componentes, caso não sejam tratados adequadamente.

c) Alelopatia: a germinação de sementes e o crescimento de plantas podem ser inibidos por compostos químicos liberados naturalmente por raízes ou partes aéreas de outras espécies. A probabilidade de ocorrência de efeitos alelopáticos de árvores sobre culturas agrícolas, e vice-versa, é grande nas 
consorciações de culturas devido ao pouco conhecimento sobre as interações entre espécies e o grande número de possíveis combinações agroflorestais.

d) Aumento dos riscos de erosão: nos sistemas agroflorestais onde o componente arbóreo apresenta um dossel muito alto e o sombreamento interfere na vegetação rasteira, é provável que ocorra um aumento da erosão do solo, causada pelo impacto de gotas de chuvas acumuladas nas folhas das árvores, tornando-se partículas maiores que caem diretamente na superfície do solo desprotegido (Vilas Boas, 1991).

\subsection{Programas Agroflorestais nas instituições de pesquisas na Amazônia}

Preocupados com o avanço da exploração florestal na Amazônia, a EmbrapaCPATU/PNPF (Amazônia Oriental) iniciou em 1979 um programa florestal com o objetivo de tentar recompor áreas degradadas e abandonadas em decorrência das atividades agrícola e pecuária.

De acordo com as espécies escolhidas e tecnologias disponíveis, os sistemas agroflorestais podem ser dirigidos para uma economia de subsistência ou de mercado.

Inicialmente foram identificados os sistemas usados pelos produtores e, após algumas modificações, foram novamente introduzidos no campo.

O estudo apresenta as espécies que são potencialmente aptas para serem utilizadas em sistemas agroflorestais na Amazônia (Tabela 1). 
Tabela 1. Espécies potenciais para diferentes cultivos associados.

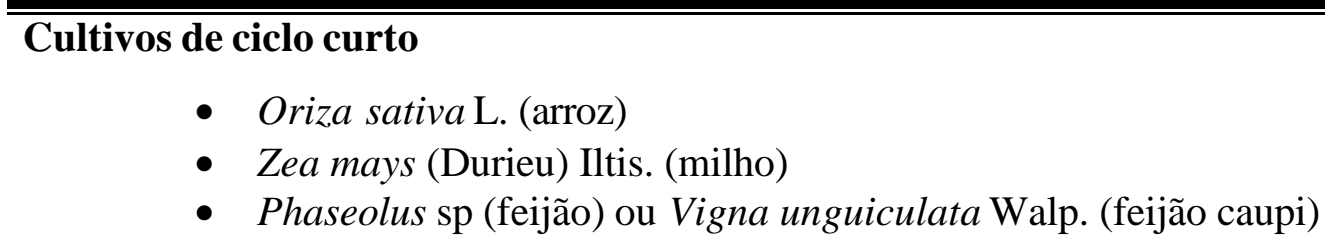

\section{Cultivos de ciclo médio}

- Manihot esculenta Crantz (mandioca)

\section{Cultivos perenes}

- Musa sp (banana)

- Theobroma cacao L. (cacau)

- Coffea sp (café)

- Paullinia cupana H.B.K. Sorbilis (Mart.) Ducke (guaraná)

- Piper nifrum L. (pimenta-do-reino)

\section{Espécies florestais}

- Cordia goeldiana Huber (freifó)

- Swietenia macrophylla (mogno)

- Bertholletia excelsa H.B.K. (castanha-do-brasil)

- Carapa guianensis Aubl. (andiroba)

- Bagassa guianensis Aubl. (tatajuba)

- Didymopanax morototoni (Aubl.) D. \& P. (morototó)

- Jacaranda copaia D. Don. (parapará)

- Simaruba amara Aubl. (marupá)

\section{Fonte: Embrapa-CPATU, 1989.}

A Embrapa-CPATU concentrou seus experimentos sobre sistemas agroflorestais nas regiões de Santarém, Capitão Poço, Tomé-Açu e Belterra no Estado do Pará desde 1980.

Os sistemas agroflorestais não devem ser considerados como única opção para o desenvolvimento de áreas sem expressão econômico-social, já que apresentaram vantagens e desvantagens. O programa recomenda a análise de cada situação e a aplicação dos sistemas com bom senso. Apesar da precocidade das observações, os SAFs são técnicas para o aproveitamento contínuo do solo altamente potenciais para a região amazônica.

A Embrapa-CPAA (Amazônia Ocidental), com sede em Manaus, vem desenvolvendo desde 1990 quatro sistemas agroflorestais distintos em seu campo 
experimental. Vale ressaltar que este trabalho é o único em fase de desenvolvimento com tal magnitude na Amazônia Legal.

\subsection{Espécies utilizadas nos sistemas agroflorestais}

Baggio (1993) e Montoya \& Batti (1994) relacionam diversas espécies que já foram identificadas e testadas, utilizadas em vários modelos agroflorestais, mas ainda existem muitas outras que merecem ser estudadas. A Tabela 2 apresenta uma relação de espécies e seus usos potenciais nos modelos agroflorestais estudados.

Tabela 2. Características das espécies e seus respectivos usos nos sistemas agroflorestais na estação experimental Embrapa/CPAA, Amazônia Ocidental.

\begin{tabular}{|c|c|c|c|}
\hline \multicolumn{2}{|c|}{ ESPÉCIES } & Práticas Agroflorestais & Usos Potenciais \\
\hline Nome Científico & Nome Popular & & \\
\hline Bactris gassipaes & Pupunha & $1,5,7$ & $\mathrm{~A}, \mathrm{E}$ \\
\hline Berthollettia excelsa & Castanheira & $1,4,5,7$ & $\mathrm{~A}, \mathrm{~B}, \mathrm{E}$ \\
\hline Brachiara brizanta & Brizantão & 6 & $\mathrm{D}$ \\
\hline Brachiara humidicola & Quicuio & 6 & $\mathrm{D}$ \\
\hline Carica papaya & Mamão & 1 & $\mathrm{E}$ \\
\hline Colubrina glandulosa & Columbrina & 1 & A, B \\
\hline Desmodium ovalifolium & Desmódio & 6 & D \\
\hline Eugenia stipitata & Araçá-boi & 1 & $\mathrm{E}$ \\
\hline Euterpe oleraceae & Açaí & $1,5,7$ & $\mathrm{~A}, \mathrm{E}$ \\
\hline Genipa americana & Jenipapo & 1 & A, E \\
\hline Gliricidia sepium & Gliricídia & $1,2,3,6,7$ & $\mathrm{~A}, \mathrm{~B}, \mathrm{C}, \mathrm{E}, \mathrm{G}$ \\
\hline Inga edulis & Ingá & $1,3,6,7$ & $\mathrm{~B}, \mathrm{C}, \mathrm{G}$ \\
\hline Malpigia glabra & Acerola & 1,5 & $\mathrm{E}$ \\
\hline Manihot esculenta & Mandioca & 1,5 & $\mathrm{E}$ \\
\hline Oriza sativa & Arroz & 1 & $\mathrm{E}$ \\
\hline Passiflora edulis & Maracujá & 1 & $\mathrm{E}$ \\
\hline Platanus sp. & Banana & 1 & $\mathrm{E}$ \\
\hline Schizolobium amazonicum & Paricá & $1,4,5,7$ & $\mathrm{~A}, \mathrm{~B}, \mathrm{~F}$ \\
\hline Swietenia macrophylla & Mogno & $1,4,5,7$ & A, B \\
\hline Tectona grandis & Teca & $1,4,5,7$ & A, B \\
\hline Theobroma grandiflorum & Cupuaçu & 5,7 & $\mathrm{E}$ \\
\hline Vigna unguiculata & Feijão & 1 & $\mathrm{E}$ \\
\hline Zea maiz & Milho & 1 & $\mathrm{E}$ \\
\hline
\end{tabular}

Fonte: Baggio (1993); Montoya \& Batti (1994).

1. Arborização de pastos/culturas

2. Barreiras vivas (corte/rebrota)

3. Cercas vivas

4. Quebra-vento

5. Revegetação de áreas degradadas

6. Banco proteína/adubo verde

7. Bosque de proteção
A - Desdobro
B - Energia
C - Apicultura
D - Forragem
E - Alimentação
F - Celulose
$\mathrm{G}$ - Adubo verde 


\section{MATERIAL E MÉTODOS}

\subsection{Caracterização da área de estudo}

Os modelos agroflorestais adotados para a realização deste estudo encontramse implantados há dez anos, na estação experimental da Embrapa/CPAA, situada no Km 54 da BR-174 (Manaus - Boa Vista - Região Norte do Brasil) em área de terra firme, entre as coordenadas geográficas $2^{0} 31^{\prime}$ a $2^{0} 32^{\prime}$ de latitude Sul e $60^{\circ} 01^{\prime}$ a $60^{\circ} 02^{\prime}$ de longitude Oeste. São os únicos em fase de desenvolvimento em áreas de pastagens degradadas e/ou abandonadas (Figura 1).
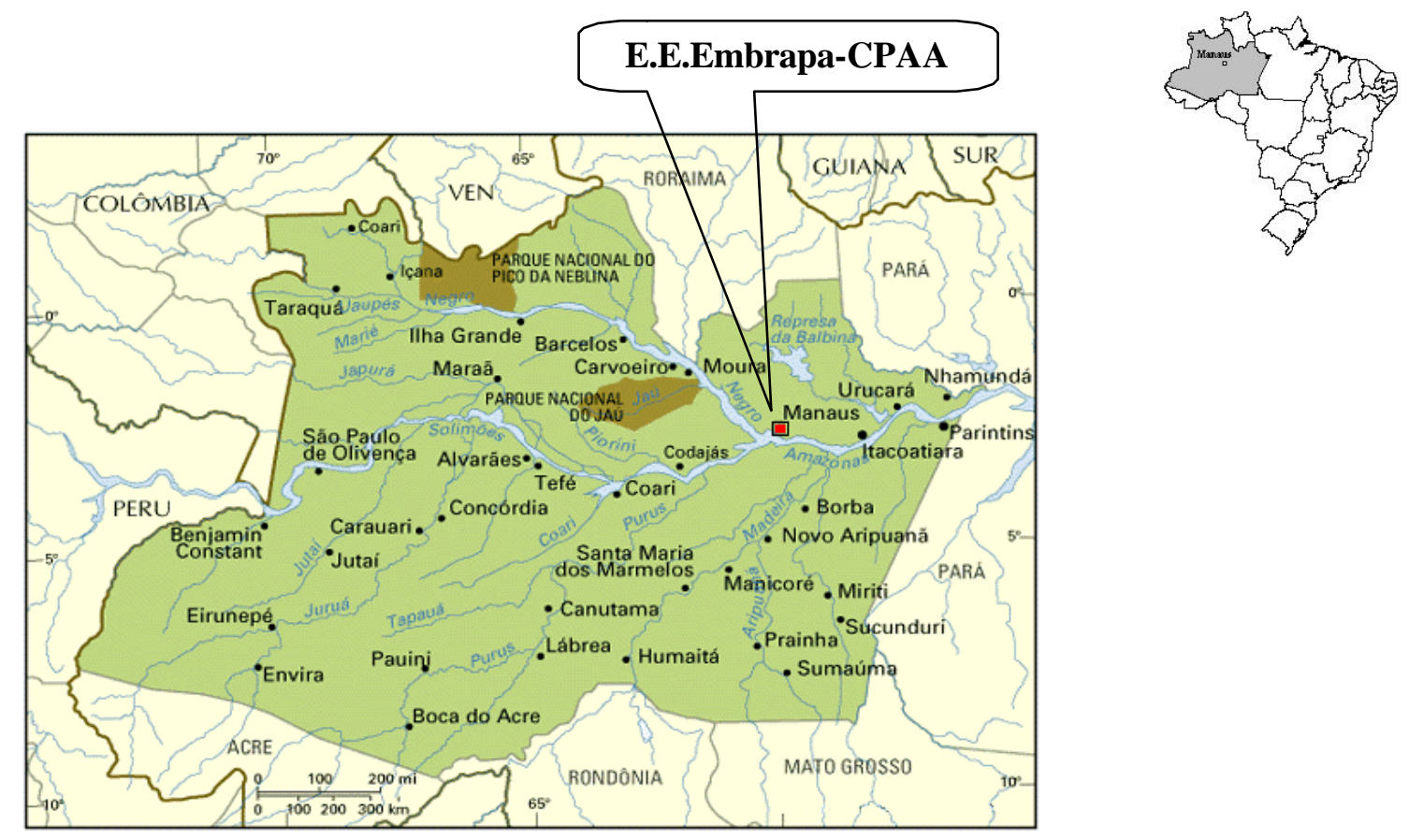

Figura 1 - E.E.Embrapa/CPAA - Manaus-AM. 


\subsection{Descrição do Distrito Agropecuário da Suframa}

A intenção inicial do Art. $1^{0}$ do Decreto-Lei $N^{0} 288$ foi incentivar a atuação da Superintendência da Zona Franca de Manaus (Suframa) no setor agropecuário, criando um distrito agropecuário nos moldes de um distrito industrial. Neste caso, reservava-se uma área delimitada para venda a produtores e empresários interessados, selecionados mediante análise de um projeto técnico apresentado à Suframa pelos proponentes. Segundo este entendimento, foi cedida à Suframa, pelo Governo do Estado do Amazonas, uma área de aproximadamente 600.000 hectares, distante 30 quilômetros de Manaus, na margem esquerda do Rio Negro, onde se implantou o DAS- Distrito Agropecuário da Suframa (Figura 2).

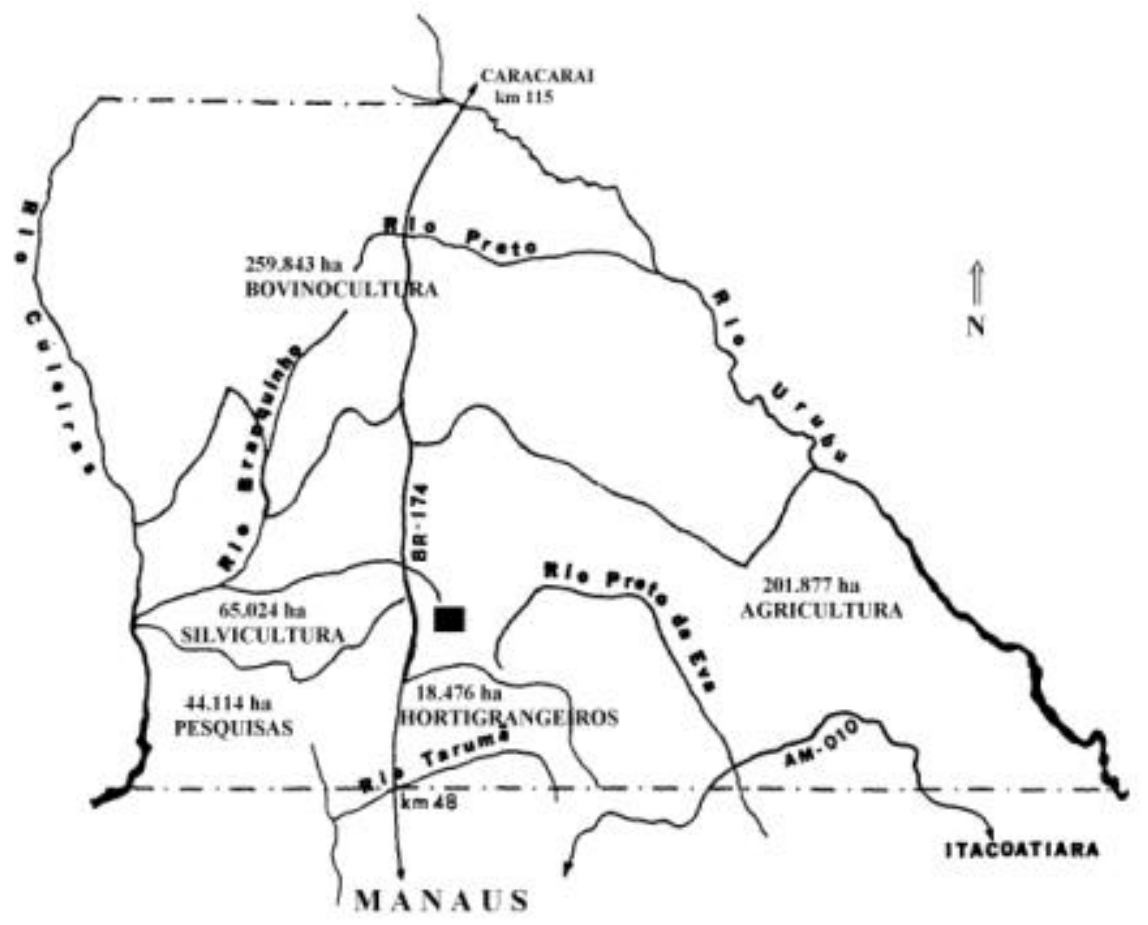

Figura 2 - $\square$ Localização da E.E.Embrapa no Distrito Agropecuário da Suframa-DAS. 
Ao longo do tempo, constatou-se que alguns projetos não se efetivaram. A implantação de pastagens, por exemplo, foi pouco eficiente e a Suframa acabou repassando boa parte dessas áreas já fragmentadas para várias entidades de assistência técnica, pesquisa e fomento da região. A Embrapa/CPPA - Amazônia Ocidental foi uma das contempladas com essa distribuição de áreas, recebendo um lote de 5.000 hectares.

\subsection{Histórico de ocupação da área}

O histórico de ocupação da área do DAS (Figura 3) tem início em 1976, quando a floresta primária foi derrubada para dar lugar à atividade pecuária. A partir de 1986, devido à baixa produtividade, o interesse por essas áreas foi diminuindo e os lotes acabaram abandonados, dando início à regeneração natural (capoeira) composta principalmente por espécies herbáceas (Borreria verticillata, Rolandra fruticosa), arbustivas e arbóreas do gênero Vismia, Solanum, Anona e Laetia (Mc. Kerrow, 1992). No inicio de 1992, a Embrapa/CPAA iniciou estudos para a recuperação da capacidade produtiva destas áreas degradadas pela atividade pecuária, adotando modelos agroflorestais como método principal.

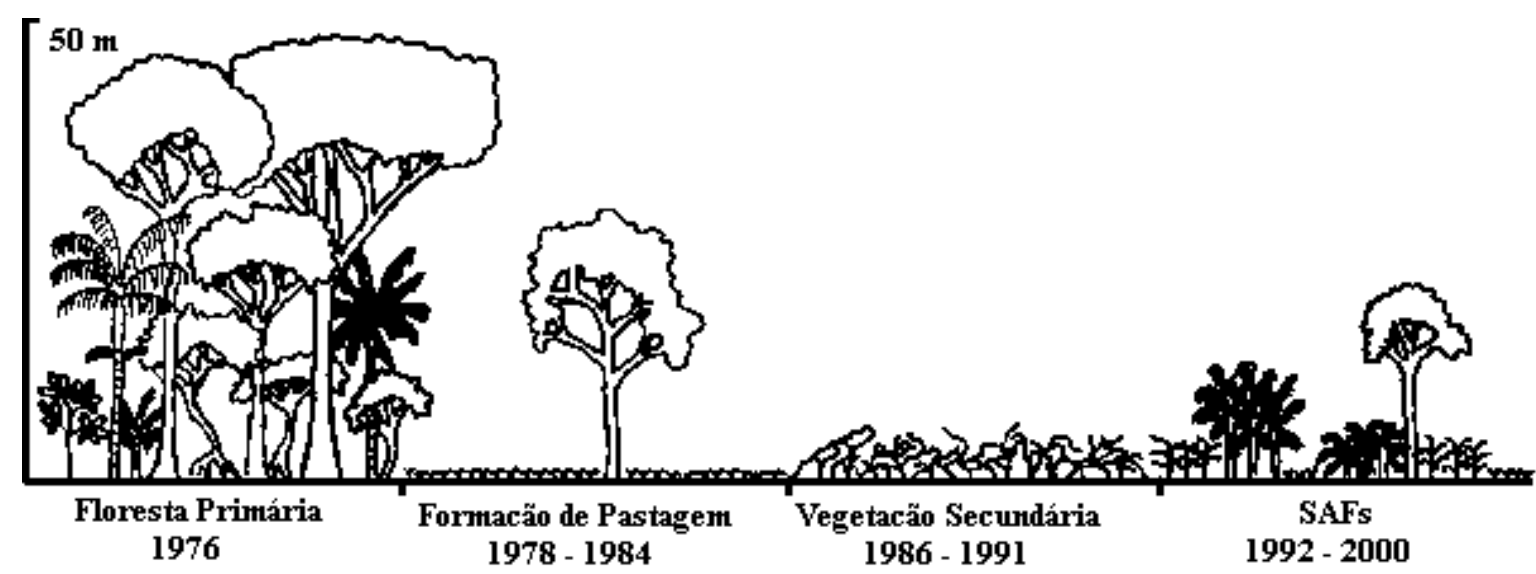

Figura 3 - Perfil do histórico de ocupação do DAS/Manaus. 


\subsection{Geomorfologia do solo da região estudada}

De acordo com a classificação de Köppen, o clima da região de estudo encontra-se no grupo climático $A$, característico de Clima Tropical Chuvoso, tipo Amw, que caracteriza-se por apresentar uma estação seca de pequena duração. As chuvas, principalmente nas áreas de clima Amw, distribuem-se em épocas distintas. Geralmente, a estação chuvosa começa em novembro ou dezembro e segue até maio ou junho e o período seco ocorre nos demais meses do ano. A precipitação pluviométrica é bastante variável, com extremos de 1300 a $2500 \mathrm{~mm}$. De maneira geral, existe um superávit hídrico de janeiro a junho e um déficit de agosto a dezembro (Fisch et al., 1998).

A umidade relativa do ar na região raramente é inferior a $70 \%$ e aproximandose freqüentemente de $90 \%$, e a luminosidade varia de 1.500 a 3.000 horas de radiação solar por ano, com um grau de nebulosidade relativamente alto (Fisch, 1998).

\subsection{Descrição dos SAFs implantados no DAS}

O delineamento experimental utilizado nos modelos agroflorestais constituiuse de blocos casualizados contendo cinco tratamentos, três repetições e a pastagem abandonada como testemunha, em parcelas de $3.000 \mathrm{~m}^{2}(60 \mathrm{~m} \times 50 \mathrm{~m})$, com uma área total de 4,5 ha (Figura 4). Os tratamentos foram distribuídos da seguinte forma: ASP1 (Sistema Agrossilvipastoril - altos insumos); ASP2 (Sistema Agrossilvipastoril - baixos insumos; AS1 (Sistema Agrossilvicultural - altos insumos com palmeiras); AS2 (Sistema Agrossilvicultural - baixos insumos multiestrato) e pastagem abandonada (testemunha).

Os sistemas agroflorestais foram compostos por culturas anuais, frutíferas e árvores. Nos sistemas agrossilvipastoris foram utilizados componentes arbóreos com culturas anuais, leguminosas de cobertura e gramíneas para suportar o componente animal.

Os modelos agroflorestais de altos insumos denominados AS1 e ASP1 receberam correção de acidez e fertilidade do solo, com aplicação de calcário, nitrogênio, fósforo e potássio. Os modelos de baixos insumos denominados AS2 e ASP2 receberam apenas uma aplicação de fósforo. 


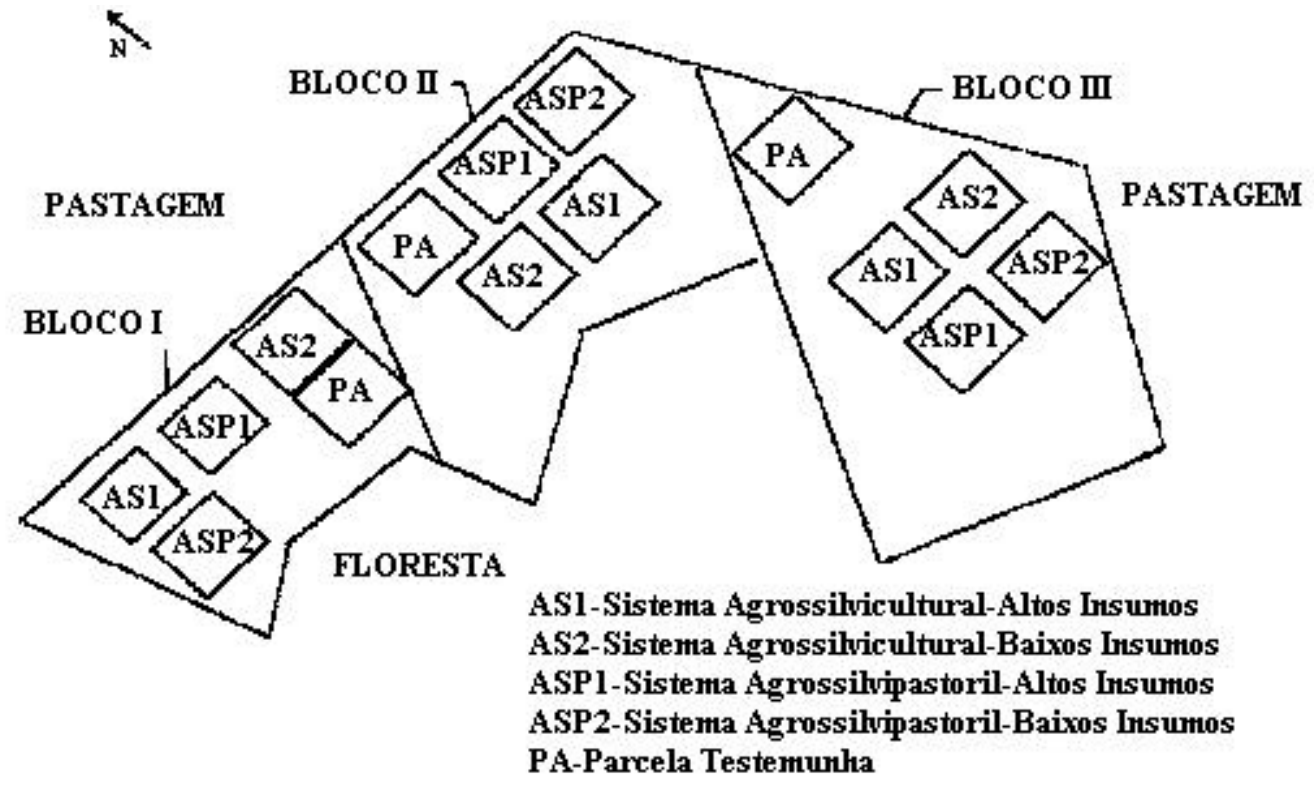

Figura 4 - Representação dos blocos estudados na E.E.Embrapa/CPAA, DAS.

\section{A) Sistema Agrossilvicultural AS1 - Sistema com base em palmeira}

Depois de derrubada e queimada a pastagem encapoeirada, foram introduzidos no primeiro ano o arroz (Oriza sativa), o cupuaçu (Theobroma grandiflorum) e a pupunheira (Bactris gassipaes) para produção de frutos e palmitos (Figura 5). Nestas culturas foram aplicados $20 \mathrm{~kg} / \mathrm{ha}$ de fósforo nas covas. Um período de seca anormal comprometeu seriamente o ciclo de produção do arroz.

No ano seguinte, o arroz foi reintroduzido utilizando espaçamento de $0,30 \mathrm{~m} \mathrm{x}$ 0,20m nas entrelinhas de mandioca (Manihot esculenta) em $1 \mathrm{~m} \times 1 \mathrm{~m}$. No terceiro ano, somente a mandioca foi introduzida utilizando o espaçamento $2 \mathrm{~m} \times 1 \mathrm{~m}$. No início de 1994, o açaí (Euterpe oleraceae) foi incorporado ao sistema com espaçamento $6 \mathrm{~m}$ x $2 \mathrm{~m}$ em linhas com o cupuaçu $(6 \mathrm{~m} \times 6 \mathrm{~m})$. No ano seguinte, foi realizada a primeira colheita de palmito (para cada três plantas de pupunheira, duas foram destinadas à produção de palmito). No mesmo período da colheita do palmito, foi introduzida a columbrina (Columbrina glandulosa) como componente arbóreo com espaçamento 12m x 6m.

Nas bordas do sistema agrossilvicultural foi introduzida a Gliricidia sepium, com espaçamento $2 \mathrm{~m} \times 2 \mathrm{~m}$, como cerca viva e fonte de adubo verde quando podadas. 


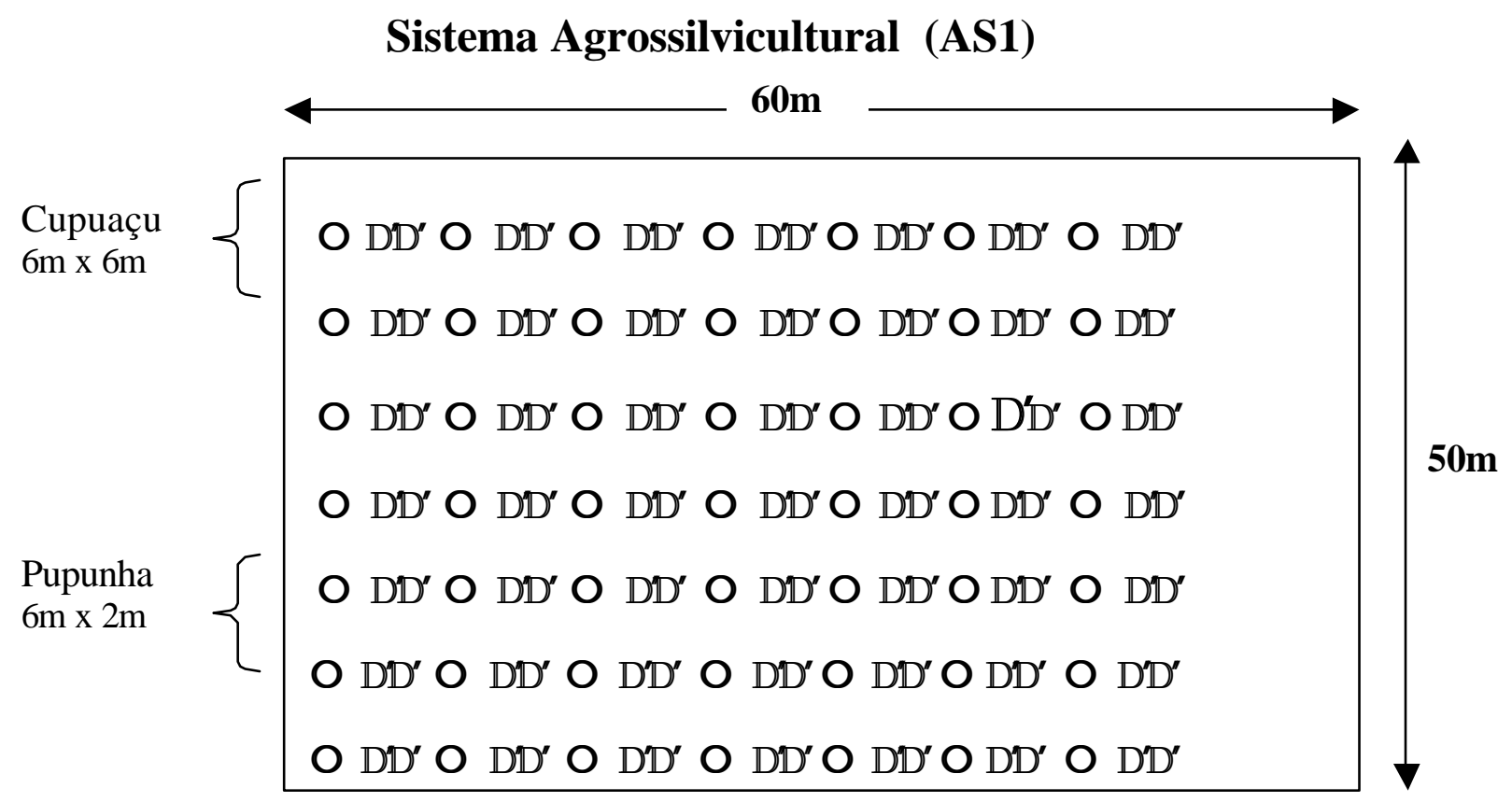

Cupuaçu O Pupunha p/ fruto $\mathbb{D}$ Pupunha $\mathrm{p} /$ palmito

Figura 5 - Distribuição espacial dos componentes do AS1.

\section{B) Sistema Agrossilvicultural AS2 - baixos insumos (multiestrato)}

A implantação deste sistema foi semelhante ao AS1, tendo, entretanto, maior diversidade de espécies frutíferas, perenes e semiperenes (Figura 6).

No primeiro ano de cultivo foi utilizado o arroz com espaçamento $0,30 \mathrm{~m} \mathrm{x}$ 0,20m, juntamente com o cupuaçu $(6 \mathrm{~m} \times 6 \mathrm{~m})$ e na seqüência foi implantada a mandioca com espaçamento $1 \mathrm{~m} \times 1 \mathrm{~m}$. Como culturas arbóreas perenes foram utilizados o mogno (Swietenia macrophylla) no espaçamento $6 \mathrm{~m} \times 6 \mathrm{~m}$ ), a castanha-do-brasil, (Berthollettia excelsa) com espaçamento igual a $10 \mathrm{~m} \times 10 \mathrm{~m}$ e a teca (Tectona grandis), em $10 \mathrm{~m} \times$ $15 \mathrm{~m}$. Como culturas frutíferas semiperenes, utilizourse o araçá-boi, (Eugenia stipitata) com espaçamento $6 \mathrm{~m}$ x 6m, o jenipapo, (Genipa americana) em $5 \mathrm{~m}$ x 2,5m, a acerola (Malpigia glabra) com distância de 2,5m x 10m, e o maracujá, (Passiflora edulis) utilizando espaçamento em linha de $12 \mathrm{~m}$ x $5 \mathrm{~m}$. 


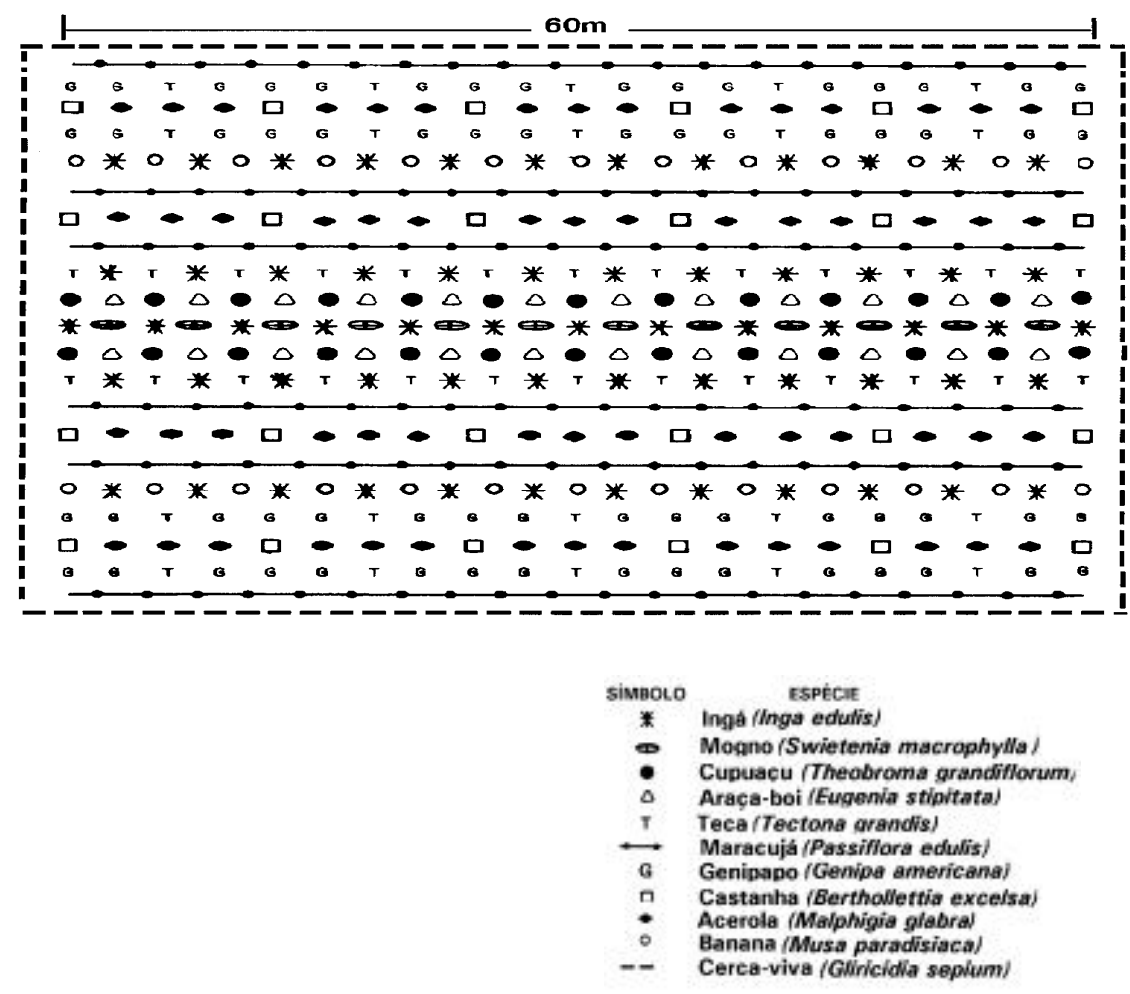

Figura 6 - Distribuição espacial dos componentes do AS2 - baixos insumos (multiestrato).

Como espécies utilizadas para a produção de adubo verde e proteção (quebravento e/ou cerca viva) utilizourse a ingá (Inga edulis) com espaçamento de $6 \mathrm{~m}$ x $6 \mathrm{~m}$ e a gliricídia (Gliridia sepium). No quinto ano (1996), foram realizadas alterações no sistema, substituindo-se $80 \%$ da teca por columbrina.

\section{C) Sistema Agrossilvipastoril ASP1 - Altos insumos}

A implantação deste sistema foi realizada com a derrubada seguida de queima da vegetação secundária e preparo do solo mecanizado através de gradagem.

Cada parcela recebeu duas toneladas de calcário por hectare, $20 \mathrm{~kg} / \mathrm{ha}$ de nitrogênio (N); 40 kg/ha de fósforo (P) e $25 \mathrm{~kg} / \mathrm{ha}$ de potássio (K). Foram cultivados,em 
seqüência, milho (Zea mays) e caupi (Vigna unguiculata) no primeiro ano e, no segundo, mandioca (M. esculenta).

Durante o cultivo do milho foram implantados os componentes madeireiros em faixas no centro das parcelas, com uma distribuição de duas árvores de paricá (Schizolobium amazonicum) seguidas por uma árvore de mogno (S. macrophylla) em linhas de 2,0 m. A ingá foi plantada com espaçamento entre linhas de $1 \mathrm{~m}$ x $1 \mathrm{~m}$ em linhas laterais ao mogno e paricá (Figura 7). A densidade das espécies arbóreas plantadas foi de 73 árvores/ha para o mogno, 133 árvores/ha para o paricá e 206 árvores/ha para a ingá. No terceiro ano foram implantadas as forrageiras, desmódio (Desmodium ovalifolium), quicuio (Brachiaria humidicola) e brizantão (Brachiaria brizanta) e no final do quarto ano foi introduzido o componente animal.

$60 \mathrm{~m}$

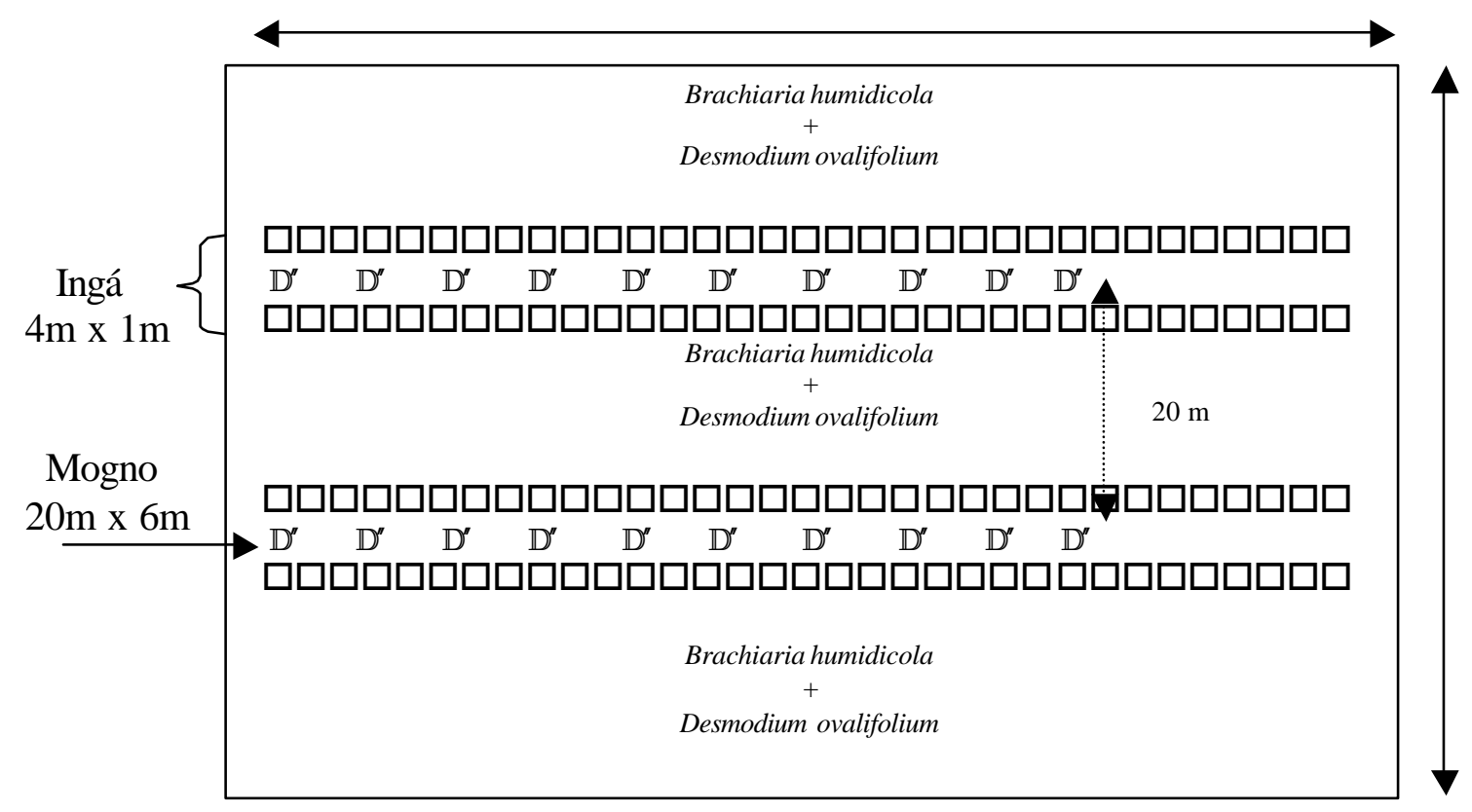

$\mathbb{D}^{\prime}$ Mogno Paricá $\square$ Ingá

Figura 7 - Distribuição espacial dos componentes do ASP1.

\section{D) Sistema Agrossilvipastoril ASP2 - baixos insumos}

Foram efetuadas a derrubada e queima da vegetação secundária e o preparo do solo com sistema manual (coivara e abertura de covas com uso de enxada). Foi aplicada uma adubação de $20 \mathrm{~kg} / \mathrm{ha}$ de fósforo $(\mathrm{P})$ no início do plantio das culturas anuais de $\operatorname{arroz}(O$. sativa) e mandioca (Figura 8). 
As espécies arbóreas como ingá, mogno e paricá tiveram tratamentos semelhantes ao ASP 1. No terceiro ano, foram introduzidas as forrageiras Brachiaria e o Desmodium em consórcio com a leguminosa gliricídia e quicuio. No quarto ano, foi introduzido o componente animal.

\section{Sistema Agrossilvipastoril (ASP2)}

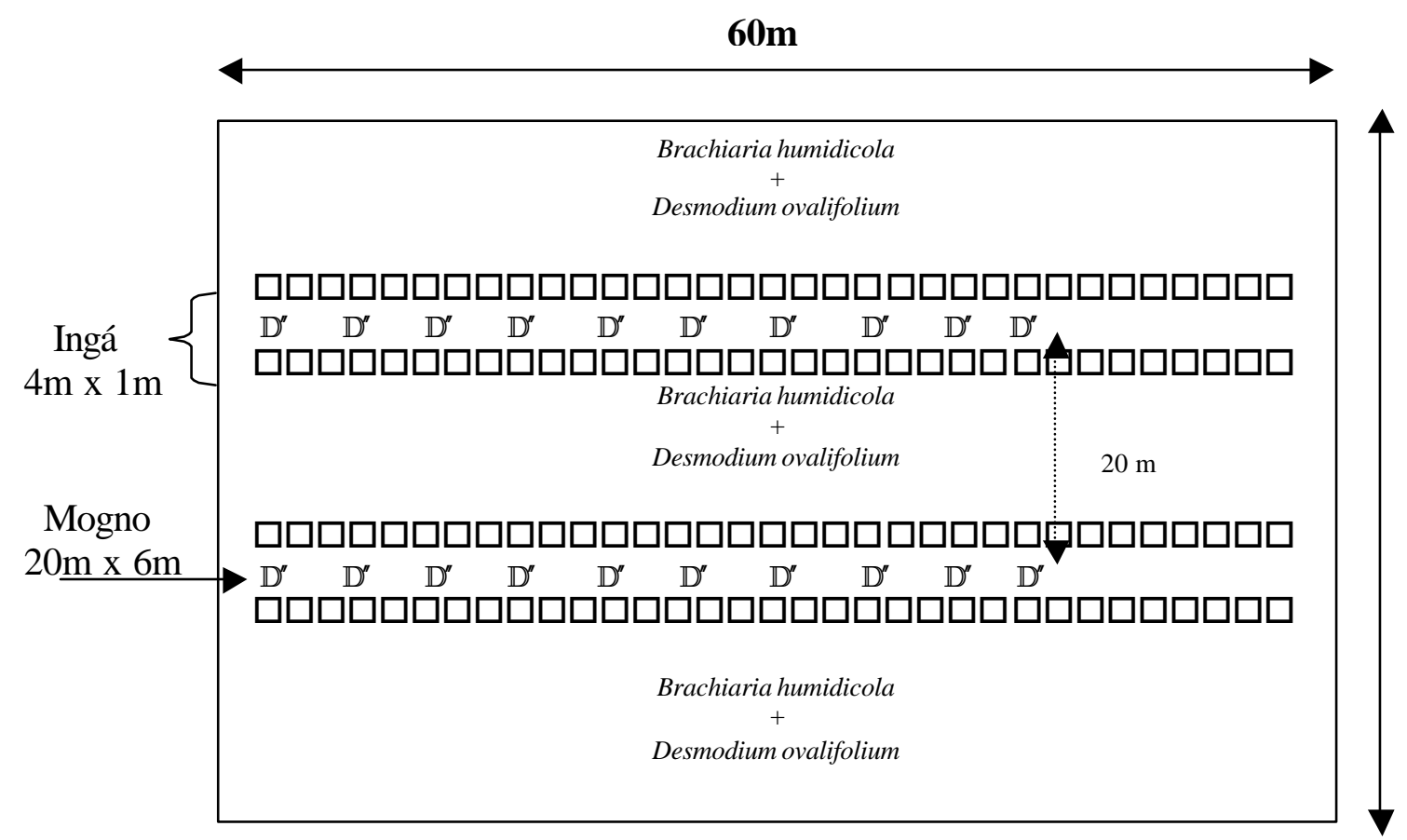

\section{$\mathbb{D}^{\prime}$ Mogno $\quad$ Paricá $\quad \square$ Ingá}

Figura 8 - Distribuição espacial dos componentes do ASP2. 


\subsection{Condições de fertilidade}

Em 1991, quando da implantação dos SAFs estudados neste trabalho, e em 1996, foram retiradas amostras para a análise da fertilidade do solo. Os dados da Tabela 3 são apresentados para uma melhor apreciação das condições de fertilidade da área onde foram implantados os SAFs em questão.

Tabela 3. Análises químicas do solo onde os SAFs foram instalados.

\begin{tabular}{|c|c|c|c|c|c|c|}
\hline Ano & $\overline{\mathbf{P H}}$ & $\begin{array}{c}P \\
\mathrm{mg} \mathrm{dm}^{-3}\end{array}$ & $\bar{K}$ & \multicolumn{2}{|c|}{$\operatorname{mmol}_{c} \mathrm{dm}^{-3}$} & $\begin{array}{l}\text { M } \\
\%\end{array}$ \\
\hline \multicolumn{7}{|c|}{ AS1 } \\
\hline 1991 & 4,4 & 2,2 & 1,4 & 12,7 & 4,7 & 34,6 \\
\hline 1996 & 4,5 & 3,0 & 0,8 & 5,4 & 2,4 & 54,9 \\
\hline \multicolumn{7}{|c|}{ AS2 } \\
\hline 1991 & 4,3 & 1,7 & 1,3 & 8,6 & 3,1 & 49,7 \\
\hline 1996 & 4,4 & 2,8 & 0,9 & 3,6 & 1,7 & 65,2 \\
\hline \multicolumn{7}{|c|}{ ASP1 } \\
\hline 1991 & 4,3 & 1,9 & 1,2 & 8,7 & 3,3 & 48,5 \\
\hline 1996 & 4,3 & 1,6 & 0,5 & 5,0 & 1,2 & 63,5 \\
\hline \multicolumn{7}{|c|}{ ASP2 } \\
\hline 1991 & 4,3 & 1,6 & 1,0 & 7,5 & 3,3 & 53,1 \\
\hline 1996 & 4,3 & 1,6 & 0,5 & 2,4 & 1,5 & 74,2 \\
\hline \multicolumn{7}{|c|}{ Testemunha } \\
\hline 1991 & 4,5 & 2,6 & 0,20 & 1,27 & 0,52 & 34,6 \\
\hline 1996 & 4,3 & 1,2 & 0,07 & 0,42 & 0,31 & 56,1 \\
\hline
\end{tabular}

Fonte: Embrapa/CPAA - Manaus, AM

O solo é classificado como latossolo amarelo distrófico, de textura argilosa, apresentando saturação de alumínio média a alta e baixa disponibilidade de fósforo. Este tipo de solo é muito freqüente na região, onde cerca de $90 \%$ dos solos são ácidos

Nota-se, a partir das informações apresentadas na Tabela 3 que, com exceção dos teores de matéria orgânica nas cinco condições e de fósforo nos sistemas AS1 e AS2, todos os demais teores sofreram redução. Esta situação pode ser indicativa de que a fertilização será imprescindível para manter a capacidade produtiva, pelo menos nestes primeiros anos de implantação dos sistemas. A perspectiva inicial de que a consorciação poderia tornar a fertilização dispensável parece não estar se comprovando com base nos dados apresentados nessa tabela. 
Novas análises, entretanto, serão necessárias no futuro para ver se essas tendências se mantêm.

\subsection{Proposta básica de avaliação econômica}

O propósito do estudo é avaliar economicamente quatro modelos agroflorestais implantados na estação experimental da Embrapa/CPAA - Amazônia Ocidental em Manaus.

Os sistemas agroflorestais foram avaliados com base em dois critérios financeiros de avaliação de projetos: o Valor Presente Líquido (VPL) e o Valor Esperado da Terra (VET). Em cada sistema foram isolados os fluxos de receitas e custos das culturas consorciadas no SAF e depois avaliadas a partir da aplicação simultânea dos dois critérios de avaliação.

Para os fluxos das culturas anuais que não se repetem dentro do sistema, utilizou-se a formula do VPL. Para os demais fluxos que perpetuam uma mesma série de ciclos, usoutse o critério do VET.

Desta forma, para cada SAF são obtidos tantos valores presentes quantas foram as culturas consorciadas. O valor presente total do SAF é obtido a partir da soma desses VP's individuais. A próxima seção descreve melhor esta proposta de avaliação.

\subsection{Definição dos fluxos de caixa e do método de avaliação}

Fluxos de caixa representam as estimativas de entradas (receitas) e saídas (despesas) de recursos monetários em um determinado projeto produtivo ao longo do tempo. O resultado líquido desses fluxos pode ser calculado subtraindo-se das receitas as despesas. Nesse processo é usado como referência um único momento no horizonte de tempo, para o qual todos os valores são atualizados através de fórmulas financeiras de acumulação ou desconto de juros. O critério do Valor Presente Líquido (VPL) usa o momento inicial do projeto como referência temporal para o cálculo. 
O VPL de um projeto é calculado da seguinte forma:

$$
V P L=\sum_{t=0}^{n} \frac{R t}{(1+i)^{t}}-\sum_{t=0}^{n} \frac{C t}{(1+i)^{t}}
$$

Onde:

Rt $=$ custo total ao final do ano ou período de tempo $t$;

$\mathrm{Ct}=$ receita total ao final do ano ou período de tempo $t$;

$i \quad=$ taxa de desconto;

$n$ = duração do projeto, em anos ou períodos de tempo.

Como critério de decisão, aceitam-se os investimentos com VPL positivo e rejeitam-se, consequientemente, os investimentos que resultem em VPL negativo. Para oportunidades de investimentos mutuamente exclusivas, escolhe-se aquela com maior VPL (Thesen, 1991).

Pode-se deduzir facilmente da expressão para cálculo do VPL que projetos com duração definida terão VPL positivo quando o valor presente das receitas (primeiro termo na subtração) for maior que o valor presente dos custos. Este principio torna evidente o fato de que VPs menores e até negativos são esperados conforme se aumenta o valor da taxa de desconto.

Essa fórmula, entretanto, serve apenas para avaliar fluxos de caixa com duração definida. Apenas algumas das culturas consorciadas nos SAFs analisados neste trabalho possuem fluxos de caixa finitos. É o caso das culturas de arroz e mandioca, por exemplo.

Outras culturas consideradas nos sistemas farão parte do consórcio permanentemente. Por exemplo, o cupuaçu e o açaí são propostos como cultivos perenes, pois serão sempre representados após o término do seu período de cultivo.

Estas culturas permanentes formam fluxos de caixa constituídos pela seqüência infinita de períodos de cultivo idênticos. $\mathrm{O}$ valor presente desses fluxos de caixa pode ser calculado se utilizadas as fórmulas para cálculo do valor presente de séries 
periódicas perpétuas (Rodriguez, 1997). De fato, o VPL do fluxo de caixa constituído pelos custos e receitas do período típico de cultivo que se repete indefinidamente pode ser usado na fórmula de cálculo do valor presente da série infinita da seguinte forma:

$$
V P L^{*}=\frac{V P L .(1+i)^{p}}{\left[(1+i)^{p}-1\right]}=\frac{V F L}{\left[(1+i)^{p}-1\right]}
$$

Onde:

$\mathrm{VPL}^{*}=$ valor presente líquido da série infinita de cultivos;

VPL = valor presente líquido de um ciclo de cultivo que se repete perpetuamente;

VFL = valor futuro líquido, no final de um ciclo de cultivo, que se repete perpetuamente;

$$
\begin{aligned}
& p=\text { período ou ciclo da cultura (rotação) } ; \\
& i=\text { taxa de desconto. }
\end{aligned}
$$

A equação (2) permite a avaliação de cultivos permanentes e é também conhecida na literatura florestal como fórmula de Faustmann ou Valor Esperado da Terra - VET (Klemperer, 1996). Este critério de avaliação representa uma série periódica perpetua de ciclos consecutivos envolvendo culturas perenes, cada uma com diferentes linhas temporais. As equações (1) e (2) constituem os critérios individuais de análise dos cultivos consorciados em cada SAF implantado no DAS pelo CPAA da Embrapa. Assim sendo, este trabalho propõe que a soma dos VPLs dos fluxos de caixa finitos que constituem o fluxo completo de receitas e custos de cada SAF seja usada como critério final de avaliação. 


\section{RESULTADOS E DISCUSSÃO}

Neste capítulo são apresentados, na forma de fluxos de caixa, os custos e receitas gerados pelos cultivos consorciados em cada SAF. Esses dados representam o resultado de levantamentos feitos localmente para a produção e comercialização dos produtos considerados nos SAFs.

Os fluxos consideram apenas as consorciações que seriam recomendadas ao produtor com base nos experimentos conduzidos, tendo como critério de seleção as produtividades obtidas nesses experimentos. Para os casos onde ainda não estão disponíveis dados sobre produtividade e também para as culturas anuais, foram consideradas produções normalmente obtidas na região em condições de monocultura e proporcionalmente distribuídas de acordo com a ocupação/densidade do componente no sistema.

As Tabelas 4, 5, 6 e 7 apresentam os percentuais de ocupação de cada componente nos sistemas. Os custos anuais de manejo e demais investimentos comuns a todos os componentes são apropriados nos respectivos fluxos de caixa de acordo com esses percentuais de ocupação. 
Tabela 4. Composição, níveis de consorciação e ciclo de cultivo dos componentes do sistema agrossilvicultural com base em palmeiras (AS1).

\begin{tabular}{|c|c|c|c|c|c|}
\hline Extrato & Componente & $\begin{array}{l}\text { Espaçamento } \\
(\mathrm{m})\end{array}$ & $\begin{array}{c}\text { Plantas } \\
\left(\text { ha }^{-1}\right)\end{array}$ & $\begin{array}{l}\text { Apropriação } \\
\text { (\% da área) }\end{array}$ & $\begin{array}{l}\text { Ciclo } \\
\text { (meses) }\end{array}$ \\
\hline \multirow{6}{*}{ Perene } & Cupuaçu & $6 \times 6$ & 278 & 15 & 240 \\
\hline & $\begin{array}{l}\text { Pupunha } \\
\text { palmito }\end{array}$ & $6 \times 2$ & 417 & 23 & 84 \\
\hline & Pupunha fruta & $6 \times 2$ & 417 & 23 & 180 \\
\hline & Açaí & $6 \times 3$ & 556 & 31 & 180 \\
\hline & Columbrina & $12 \times 6$ & 139 & 8 & 180 \\
\hline & Total de planta & por hectare: & 2.638 & 100 & \\
\hline \multirow{3}{*}{ Anual } & Arroz & $0,3 \times 0,2$ & 100.000 & - & 6 \\
\hline & Mandioca & $2 \times 1$ & 3.300 & - & 8 \\
\hline & \multicolumn{2}{|c|}{ Total de plantas por hectare: } & 103.300 & - & - \\
\hline & Centrosema & - & - & - & 6 \\
\hline Adubo & Mucuna & - & - & - & 4 \\
\hline \multirow[t]{2}{*}{ Verde } & Gliricídia & $2 \times 2$ & 2.500 & - & 240 \\
\hline & \multicolumn{2}{|c|}{ Total de plantas por hectare: } & 2.500 & - & _ \\
\hline
\end{tabular}

Fonte: Resultados desta pesquisa

No AS1, em termos de ocupação de área, a pupunha se destaca com 50\% da área plantada e com densidade em torno de 834 plantas/ha. A ocupação da pupunha, assim como dos outros componentes do AS1, é datalhada na Tabela 4. Além do percentual de apropriação da pupunha, $31 \%$ está ocupado pelos componente açaí, $15 \%$ cupuaçu e $8 \%$ pela columbrina.

As culturas agrícolas anuais (arroz e mandioca) foram incorporadas nas entrelinhas do cupuaçu em linhas duplas, permitindo uma densidade de 100.000 e 3.300 plantas/ha respectivamente.

O componente arbóreo gliricídia teve papel importante tanto na função do acúmulo de biomassa no solo quanto na de proteção (cerca-viva). 
Tabela 5. Composição, níveis de consorciação e ciclo de cultivo dos componentes do sistema agrossilvicultural multiestrato (AS2).

\begin{tabular}{|c|c|c|c|c|c|}
\hline Estrato & Componente & $\begin{array}{c}\text { Espaçamento } \\
\text { (m) }\end{array}$ & $\begin{array}{c}\text { Plantas } \\
\left(\text { ha }^{-1}\right)\end{array}$ & $\begin{array}{c}\text { Apropriação } \\
\text { (\% da área) }\end{array}$ & $\begin{array}{c}\text { Ciclo } \\
\text { (meses) }\end{array}$ \\
\hline \multirow{11}{*}{ Perene } & Cupuaçu & $6 \times 6$ & 278 & 8,40 & 240 \\
\hline & Mogno & $6 \times 6$ & 833 & 25,21 & 300 \\
\hline & Teca & $10 \times 5$ & 200 & 6,05 & 180 \\
\hline & Ingá & $6 \times 6$ & 278 & 8,40 & 240 \\
\hline & Castanha do & & & & \\
\hline & brasil & $10 \times 10$ & 100 & 3,03 & 360 \\
\hline & Acerola & $2,5 \times 10$ & 400 & 12,10 & 180 \\
\hline & Araçá-boi & $6 \times 6$ & 278 & 8,40 & 180 \\
\hline & Jenipapo & $5 \times 2,5$ & 800 & 24,20 & 240 \\
\hline & Maracujá & $12 \times 5$ & 167 & 4,20 & 48 \\
\hline & Total de planta & or hectare: & 3.305 & 100 & - \\
\hline \multirow{4}{*}{ Anual } & Arroz & $0,3 \times 0,2$ & 100.000 & - & 6 \\
\hline & Mandioca & $1 X 1$ & 10.000 & - & 8 \\
\hline & Total de planta & or hectare: & 110.000 & - & - \\
\hline & Gliricídia & $2 \times 2$ & 2.500 & - & 240 \\
\hline \multirow{3}{*}{$\begin{array}{c}\text { Adubo } \\
\text { Verde }\end{array}$} & Centrosema & - & - & - & 6 \\
\hline & Mucuna & - & - & - & 4 \\
\hline & Total de planta & or hectare: & 2.500 & - & - \\
\hline
\end{tabular}

Fonte: Resultados desta pesquisa

Por se tratar de um sistema multiestrato, observa-se, conforme a Tabela 5, que existe um maior número de espécies consorciadas em relação aos demais sistemas adotados. Nota-se que para as culturas perenes frutíferas, o jenipapo ocupou a maior parte da área (25\%), a acerola se estendeu por $12 \%$, o cupuaçu e o araçá-boi chegaram a $8 \%$ e o maracujá ocupou $4 \%$.

Nos componentes madeireiros, o mogno predominou com (25\%) em termos de ocupação da área no sistema $(8 \%)$ foi ocupado pela ingá $(6 \%)$ pela teca e $(3 \%)$ castanha-do-brasil.

O que diferencia os dois sistemas agrossilvipastoril ASP1 e ASP2 (Tabelas 6 e 7) é a presença de espécies anuais e de pastagens com diferentes densidades por hectare. 
Tabela 6. Composição, níveis de consorciação e ciclo de cultivo dos componentes do sistema agrossilvipastoril de alto insumo (ASP1).

\begin{tabular}{llcccc}
\hline \hline Estrato & Componente & $\begin{array}{c}\text { Espaçamento } \\
(\mathrm{m})\end{array}$ & $\begin{array}{c}\text { Plantas } \\
\left(\mathrm{ha}^{-1}\right)\end{array}$ & $\begin{array}{c}\text { Apropriação } \\
(\% \text { da área })\end{array}$ & $\begin{array}{c}\text { Ciclo } \\
(\text { meses })\end{array}$ \\
\hline \multirow{5}{*}{ Perene } & Ingá & 6 X 6 & 278 & 9,09 & 240 \\
& Mogno & 6 X 6 & 278 & 9,09 & 300 \\
& Paricá & 2 X 2 & 2.500 & 81,82 & 180 \\
& Total de plantas por hectare: & $\mathbf{3 . 0 5 5}$ & $\mathbf{1 0 0}$ & - \\
\hline \multirow{5}{*}{ Anual } & Milho & 0,5 X 0,4 & 15.000 & - & 6 \\
& Caupi & 0,3 X 0,1 & 66.400 & - & 6 \\
& Mandioca & 1 X 1 & 10.000 & - & 8 \\
\multirow{2}{*}{ Adubo } & Total de plantas por hectare: & $\mathbf{9 1 . 4 0 0}$ & - & - \\
Verde & Gliricídia & 2 X 2 & 2.500 & - & 240 \\
& Mucuna & - & - & - & 4 \\
& Total de plantas por hectare: & $\mathbf{2 . 5 0 0}$ & - & - \\
\multirow{2}{*}{ Pasto } & Quicuio & - & - & - & 6 \\
& Desmodium & - & - & - & 6 \\
\hline \hline
\end{tabular}

Fonte: Resultados desta pesquisa

Em ambos os sistemas agrossilvipastorís o componente madeireiro paricá predomina com $82 \%$ da ocupação da área, e o restante $9 \%$ com a ingá e o mogno.

Tabela 7. Composição, níveis de consorciação e ciclo de cultivo dos componentes do sistema agrossilvipastoril de baixo insumo (ASP2).

\begin{tabular}{|c|c|c|c|c|c|}
\hline Estrato & Componente & Espaçamento & $\begin{array}{c}\text { Plantas } \\
\left(\mathrm{ha}^{-1}\right)\end{array}$ & $\begin{array}{r}\text { Apropriação } \\
\text { (\% da área) }\end{array}$ & $\begin{array}{c}\text { Ciclo } \\
\text { (meses) }\end{array}$ \\
\hline \multirow{4}{*}{ Perene } & Ingá & $6 \times 6$ & 278 & 9,09 & 240 \\
\hline & Mogno & $6 \times 6$ & 278 & 9,09 & 300 \\
\hline & Paricá & $2 \times 2$ & 2.500 & 81,82 & 180 \\
\hline & Total de plant & por hectare: & 3.055 & 100 & - \\
\hline \multirow{3}{*}{ Anual } & Arroz & $0,3 \times 0,2$ & 100.000 & - & 5 \\
\hline & Mandioca & $1 \times 1$ & 10.000 & - & 8 \\
\hline & Total de plant & por hectare: & 110.000 & - & - \\
\hline \multirow{4}{*}{$\begin{array}{l}\text { Adubo } \\
\text { Verde }\end{array}$} & Gliricídia & $2 \times 2$ & 2.500 & - & 6 \\
\hline & Mucuna & - & - & - & 6 \\
\hline & Total de plant & por hectare: & 2.500 & - & - \\
\hline & Quicuio & - & - & - & 6 \\
\hline Pasto & Desmodium & - & - & - & 5 \\
\hline
\end{tabular}

Fonte: Resultados desta pesquisa 


\subsection{Fluxos de caixa}

Os fluxos de caixa apresentados nas Figuras 9, 10, 11 e 12 representam, para cada sistema, as entradas e saídas anuais de recursos. Permitem também observar a partir de quando as culturas oferecem produção para a geração de receitas.

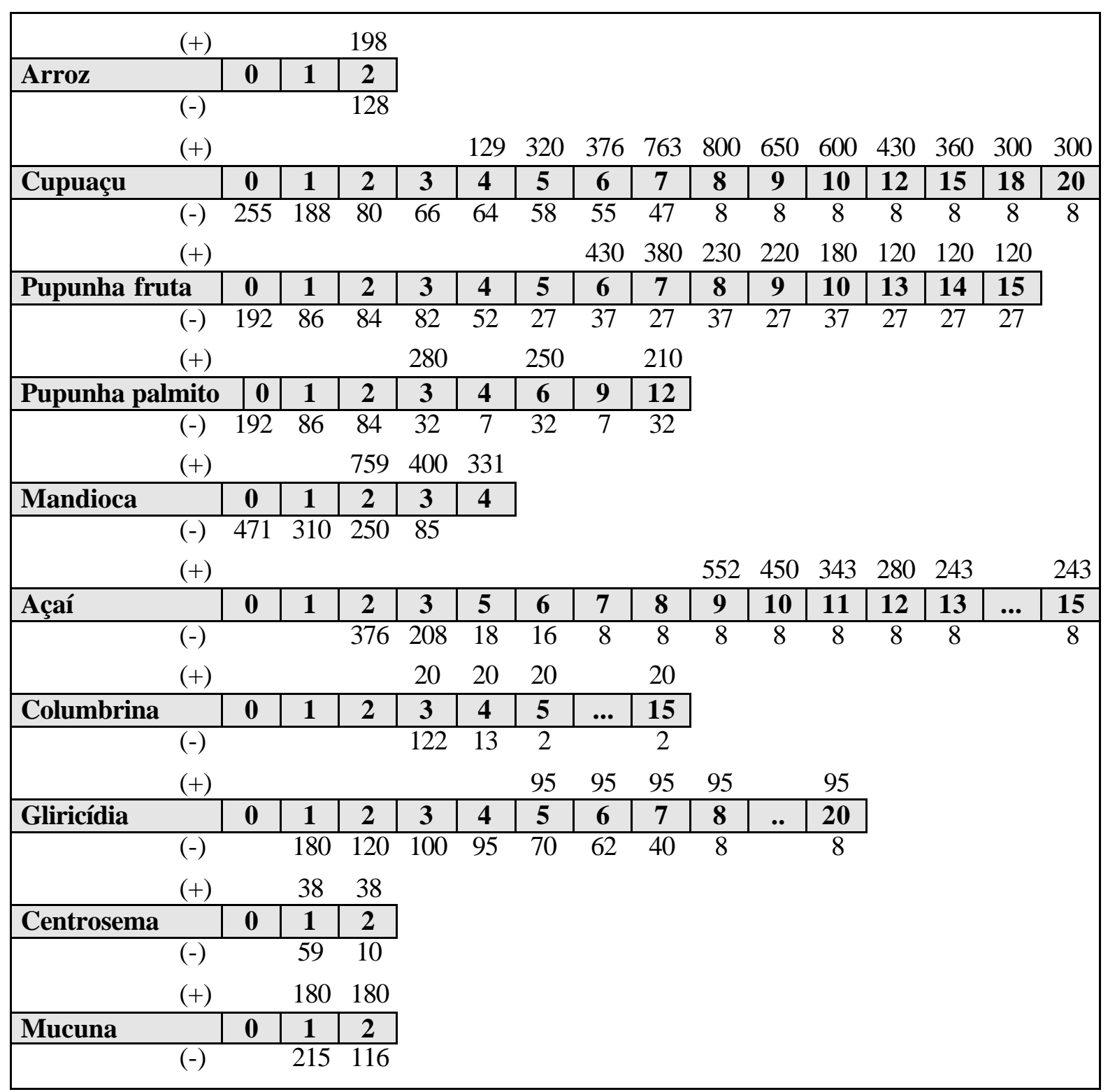

Figura 9 - Representação do fluxo da caixa do sistema AS1 com base em palmeiras 
Na cultura do arroz foi determinada uma densidade de 100.000 plantas/ha e produção média de 2,6 ton/ha. A cultura foi estabelecida somente por um ano. O valor do produto no mercado foi estimado em $\mathrm{R} \$ 0,85 \mathrm{~kg}$, considerando-se que na negociação é usado o desconto de $60 \%$, sobrando para o produtor $\mathrm{R} \$ 0,32 / \mathrm{kg}$.

Com este cenário, chegourse a valores de $\mathrm{R} \$ 198,00$ ha/ano, o que corresponde a $619 \mathrm{~kg} / \mathrm{ha} / \mathrm{ano}$. Os custos desta cultura são atribuídos a atividades como plantio/adubação e colheita ( $\mathrm{R} \$ 125,00)$. O fluxo de caixa deste sistema considera que a cultura do cupuaçu tem densidade de 278 plantas/há (Tabela 10) e sua produção é estimada, a partir do $5^{\circ}$ ano de plantio, em aproximadamente 2.780 frutos/ha (média de 10 frutos/planta), podendo alcançar 5.838 frutos (aproximadamente 21 frutos/plantas) no $8^{\circ}$ ano. $\mathrm{O}$ preço de venda do produto no mercado foi estimado no período de safra em média a R\$ 1,00 o quilo do fruto. Para o referido estudo, considerourse o produto negociado em nível de produtor, ou seja, na propriedade, utilizando desconto de $60 \%$ em relação ao valor no mercado ( $\mathrm{R} \$ 0,40 \mathrm{~kg} /$ fruto).

Adotando este critério, considerou-se que na primeira colheita a produção foi de $322 \mathrm{~kg} / \mathrm{ha}$ (R $\$ 129,00)$ e na segunda colheita, houve um crescimento de aproximadamente $60 \%$ (800 kg/ha), gerando uma receita de $\mathrm{R} \$ 320,00$.

Conforme apresentado no fluxo de caixa (Figura 9), houve um crescimento até o $8^{\circ}$ ano, a partir deste período ocorreu um decréscimo até o $11^{\circ}$ e uma estabilização até o final do ciclo (20 anos).

Os custos apresentados na cultura do cupuaçu referem-se às despesas tais como preparo do solo $(\mathrm{R} \$ 255,00)$, preparo de mudas $(\mathrm{R} \$ 188,00)$, plantio $(80,00)$, replantio $(\mathrm{R} \$ 66,00)$, colheitas em diferentes estágios $(\mathrm{R} \$ 64,00 ; \mathrm{R} \$ 68,00 ; \mathrm{R} \$ 55,00$ e $\mathrm{R} \$ 47,00)$ e manutenção/colheita $(R \$ 8,00)$ até o final do ciclo.

Para a pupunha destinada à produção de fruto, obedecełse a uma linha temporal de 15 anos, perfazendo um total de 417 plantas/ha, com produção na ordem de 2,0 kg/pupunha/planta. O valor do produto no mercado local (Manaus) foi estimado em média de $\mathrm{R} \$ 1,20 \mathrm{~kg} /$ fruto. Usando o mesmo critério de desconto (60\%), o valor do produto negociado na propriedade é de $\mathrm{R} \$ 0,72$ o quilo. 
Observa-se que a partir do $\tau$ ano a pupunha obteve sua primeira produção (597 kg/ha), gerando uma receita inicial de $\mathrm{R} \$ 430,00$. Nos anos seguintes, detectourse uma ligeira queda na produção ( $34 \%$ no $8^{\circ}$ ano e $17 \%$ no $9^{\circ}$ ano) e estabilidade da colheita a partir do $13^{\circ}$ ano até o final do ciclo.

Quanto à produção da pupunha/palmito, utilizoułse a mesma densidade da pupunha/fruto (417 plantas/ha). Em termos de produtividade, adotou-se a média de 0,8 $\mathrm{kg}$ de palmito/planta $(334 \mathrm{~kg} / \mathrm{ha})$, com produção a partir do $4^{\mathrm{o}}$ ano. $\mathrm{O}$ nível de mercado do referido produto foi estimado em $\mathrm{R} \$ 1,50 \mathrm{~kg}$ in natura e $\mathrm{R} \$ 0,42$ na propriedade.

No ano pré-estabelecido, a pupunha/palmito rendeu ao sistema R \$ 280,00 (667 $\mathrm{kg} / \mathrm{ha} / \mathrm{ano}), \mathrm{R}$ \$ 250,00 (595 kg/ha/ano) três anos depois e $\mathrm{R} \$ 210,00$ (500 kg/ha/ano) respectivamente. Os custos apresentados nos anos em que antecederam a primeira produção referem-se às atividades de preparo do solo $(\mathrm{R} \$ 192,00)$, preparo de mudas ( $\mathrm{R} \$ 86,00)$, plantio ( $\mathrm{R} \$ 84,00)$ e colheita $(\mathrm{R} \$ 32,00)$. Os de demais custos representam as mesmas atividades ao longo da linha temporal de 15 anos.

Para o plantio da mandioca, foi estabelecida uma densidade de 3.300 plantas/ha com potencial para produzir 4,9 ton/ha (média de 1,5 $\mathrm{kg}$ deraiz/planta). A cultura foi estabelecida por três anos consecutivos. O valor do produto no mercado foi estimado em $\mathrm{R} \$ 0,50 \mathrm{~kg}$ e em nível do produtor, este valor foi fixado em $\mathrm{R} \$ 0,20 \mathrm{~kg} / \mathrm{raiz}$.

Com este cenário, foram observados os valores de $\mathrm{R} \$ 759,00 /$ ha/ano, o que corresponde a $3.795 \mathrm{~kg} / \mathrm{ha} / \mathrm{ano}$ na primeira colheita, R $\$$ 400,00/ha/ano (2.000 $\mathrm{kg} / \mathrm{ha} / \mathrm{ano})$ no segundo ano de produção e $\mathrm{R} \$ 331,00 / \mathrm{ha} / \mathrm{ano}(1.655 \mathrm{~kg} / \mathrm{ha} / \mathrm{ano})$ no terceiro ano. Observa-se que os anos em que se estabeleceu a mandioca, houve um decréscimo de até $56 \%$ em nível de produção; estes valores são esperados devido às exigências nutricionais desta cultura.

Os custos das atividades envolvidas na cultura da mandioca decorrem das despesas com preparo de mudas e plantio $(\mathrm{R} \$ 781,00)$ nos dois primeiros anos, $(\mathrm{R} \$$ $250,00)$ adubação e colheita no terceiro ano e $\mathrm{R} \$ 115,00$ utilizados na atividade de colheita. 
Para a cultura do açaí foi definido um horizonte produtivo de 15 anos com produção a partir do $7^{\circ}$ ano. No sistema, o açaí teve uma densidade de 556 plantas/ha, com apropriação de $31 \%$ da área. Foi realizada uma previsão de dois cachos de frutos/ano, sendo que cada cacho contém em média três quilos de frutos. $\mathrm{O}$ valor do produto no mercado foi estimado em $\mathrm{R} \$ 1,00 / \mathrm{kg}$ e em nível de produtor, a $\mathrm{R} \$ 0,40 / \mathrm{kg}$. Conforme representado na Figura 8, no primeiro ano de produção, o açaí rendeu ao sistema R \$ 552,00/ha/ano, correspondente a $1.380 \mathrm{~kg} / \mathrm{ha} / \mathrm{ano}$, e $\mathrm{R} \$ 450,00$ (1.125 $\mathrm{kg} / \mathrm{ha} / \mathrm{ano})$ no segundo ano.

Os custos representados no fluxo de caixa aplicam-se a atividades com preparo de mudas ( $\mathrm{R}$ \$ 376,00), plantio/replantio ( $\mathrm{R}$ \$ 280,00), adubação/manutenção $(\mathrm{R}$ \$ 18,00), manutenção e colheita nos períodos de produção $(\mathrm{R} \$ 8,00)$, e $\mathrm{R} \$ 8,00$ em manutenção até o final do estabelecimento da cultura. 


\begin{tabular}{|c|c|c|c|c|c|c|c|c|c|c|c|c|c|c|c|}
\hline \multirow{4}{*}{ Cupuaçu } & $(+)$ & & & & & 5 & 52 & 168 & 409 & 436 & 991 & 750 & 400 & 250 & 250 \\
\hline & & $\mathbf{0}$ & 1 & 2 & 3 & 4 & 5 & 6 & 6 & 7 & 8 & 10 & 13 & 15 & 20 \\
\hline & $(-)$ & 150 & 145 & 130 & 105 & 100 & 100 & 9 & 9 & 9 & 9 & 9 & 9 & 9 & 9 \\
\hline & $(+)$ & & 118 & & & & & & & & & & & & \\
\hline \multirow{3}{*}{ Arroz } & & $\mathbf{0}$ & 1 & & & & & & & & & & & & \\
\hline & $(-)$ & & 85 & & & & & & & & & & & & \\
\hline & $(+)$ & & & & & & & & & 444 & & & & & \\
\hline \multirow[t]{3}{*}{ Mogno } & & 0 & 1 & 2 & 3 & 4 & 5 & 6 & $\ldots$ & 25 & & & & & \\
\hline & $(-)$ & 51 & 47 & 46 & 45 & 43 & 38 & 4 & & 4 & & & & & \\
\hline & $(+)$ & & & & & & 3840 & & & & & & & & \\
\hline \multirow[t]{3}{*}{ Teça } & & $\mathbf{0}$ & 1 & 2 & 3 & $\ldots$ & 15 & & & & & & & & \\
\hline & $(-)$ & 59 & 58 & 53 & 7 & & 7 & & & & & & & & \\
\hline & $(+)$ & & & 104 & 4 & 0 & 150 & & & & & & & & \\
\hline \multirow{3}{*}{ Mandioca } & & 0 & 1 & 2 & 3 & 4 & & & & & & & & & \\
\hline & $(-)$ & 36 & 280 & 320 & 197 & 83 & & & & & & & & & \\
\hline & $(+)$ & & & & 65 & & 65 & & & & & & & & \\
\hline \multirow{3}{*}{ Ingá } & & 0 & 1 & 2 & 3 & $\ldots$ & 20 & & & & & & & & \\
\hline & $(-)$ & 136 & 129 & 102 & 7 & & 7 & & & & & & & & \\
\hline & $(+)$ & & & & & 230 & & 198 & 198 & 85 & & 85 & & & \\
\hline \multirow{3}{*}{ Castanha Brasil } & & 0 & 1 & 2 & $\ldots$ & 11 & $\ldots$ & 13 & 20 & 21 & $\ldots$ & 30 & & & \\
\hline & $(-)$ & 63 & 54 & 50 & & 46 & & 46 & 8 & 8 & & 8 & & & \\
\hline & $(+)$ & & & & 67 & 92 & 130 & 95 & & 95 & & & & & \\
\hline \multirow[t]{3}{*}{ Acerola } & & 0 & 1 & 2 & 3 & 4 & 5 & 6 & $\ldots$ & 15 & & & & & \\
\hline & $\overline{(-)}$ & 127 & 111 & 59 & 4 & & 4 & 4 & & 4 & & & & & \\
\hline & $(+)$ & & & & & & & 80 & 80 & & & & & & \\
\hline \multirow[t]{3}{*}{ Centrosema } & & 0 & 1 & 2 & 3 & 4 & 5 & 6 & 7 & & & & & & \\
\hline & $(-)$ & & & & & & & 27 & 17 & & & & & & \\
\hline & $(+)$ & & & 157 & 157 & & & & & & & & & & \\
\hline \multirow[t]{3}{*}{ Mucuna } & & 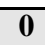 & 1 & 2 & 3 & & & & & & & & & & \\
\hline & $(-)$ & & 131 & 89 & 56 & & & & & & & & & & \\
\hline & $(+)$ & & & & & 95 & 95 & 95 & 95 & 95 & & 95 & & & \\
\hline \multirow[t]{3}{*}{ Gliricídia } & & 0 & 1 & 2 & 3 & 4 & 5 & 6 & 7 & 8 & $\ldots$ & 20 & & & \\
\hline & $(-)$ & & 117 & 109 & 101 & 91 & 80 & 54 & 27 & 8 & & 8 & & & \\
\hline & $(+)$ & & & & & & 138 & 929 & 315 & 110 & & & & & \\
\hline \multirow[t]{3}{*}{ Maracujá } & & 0 & 1 & 2 & 3 & 4 & 5 & 6 & 7 & 8 & & & & & \\
\hline & $(-)$ & & & 206 & 180 & 177 & 174 & 125 & 100 & 53 & & & & & \\
\hline & $(+)$ & & & & & & & 200 & 180 & & 155 & 155 & & 104 & 104 \\
\hline \multirow{3}{*}{ Jenipapo } & & 0 & 1 & 2 & 3 & 4 & 5 & 6 & 7 & $\ldots$ & 16 & 17 & $\ldots$ & 19 & 20 \\
\hline & $(-)$ & 127 & 88 & 46 & 25 & 23 & 4 & 4 & 4 & & 4 & 4 & & 4 & 4 \\
\hline & $(+)$ & & & 30 & 52 & 58 & 54 & & 54 & & & & & & \\
\hline Araçá-boi & & o & 1 & 2 & 3 & 4 & 5 & $\ldots$ & 15 & & & & & & \\
\hline & $(-)$ & 70 & & 54 & 46 & 8 & 8 & & 8 & & & & & & \\
\hline
\end{tabular}

Figura 10 - Representação do fluxo de caixa no sistema AS2 - (multiestrato) 
Na cultura do cupuaçu, a densidade é de 278 plantas/ha e sua produção estimada a partir do $5^{\circ}$ ano de plantio, com aproximadamente 2.780 frutos (média de 10 frutos/planta) podendo alcançar 5.838 frutos (aproximadamente 21 frutos/plantas) no $10^{\circ}$ ano - a média de peso para cada fruto foi estimado em $1,1 \mathrm{~kg} /$ fruto.

O preço de venda do produto no mercado foi, em média, R $\$ 1,00$ o quilo do fruto. Para o referido estudo, considerou-se o produto negociado em nível de produtor (na propriedade), com desconto de $60 \%$ em relação ao valor de mercado ( $\mathrm{R} \$ 0,40$ $\mathrm{kg} /$ fruto).

Adotando este critério, constatou-se que na primeira colheita ( $\operatorname{anos} 5$ e 6), a produção foi de $142 \mathrm{~kg} / \mathrm{ha}(\mathrm{R} \$ 57,00)$ e $420 \mathrm{~kg} / \mathrm{ha}(\mathrm{R} \$ 168,00)$ respectivamente (Figura 11). No ano nove, observa-se um ganho máximo de $\mathrm{R} \$ 991,00 \mathrm{~kg} / \mathrm{ha}$ correspondente a $2.477 \mathrm{~kg} / \mathrm{ha}$. A partir do $10^{\circ}$ ano, houve uma pequena baixa na produção até o $18^{\circ}$ período, tornando-se estável até o estabelecimento final da cultura.

Os custos apresentados na cultura do cupuaçu referem-se às despesas com preparo do solo $(\mathrm{R} \$ 150,00)$, preparo das mudas $(\mathrm{R} \$ 145,00)$, plantio $(130,00)$, replantio $(\mathrm{R} \$ 105,00)$, poda $(\mathrm{R} \$ 100,00)$, colheita e poda em diferentes estágios ( $\mathrm{R} \$ 100,00)$ e manutenção/colheita (R\$ 9,00) até o final do ciclo.

Neste sistema, foi determinado uma densidade e média de produção para a cultura do arroz semelhante ao sistema AS1 (100.000 plantas/ha e 2,6 ton/ha). A cultura foi estabelecida somente por um ano. O valor do produto no mercado foi estimado em $\mathrm{R} \$ 0,85$ o quilo, considerando-se o desconto de $60 \%$, o produtor recebe, com a venda na propriedade, $\mathrm{R} \$ 0,32$ pelo quilo.

No referido sistema, o arroz apresentou baixa produtividade em relação aos demais. A produção do arroz rendeu ao sistema $\mathrm{R}$ \$ 118,00/ha/ano, correspondentes a $368 \mathrm{~kg} / \mathrm{ha} / \mathrm{ano}$. Os custos desta cultura são atribuídos a atividades como plantio/adubação e colheita $(\mathrm{R} \$ 85,00)$.

O componente madeireiro mogno apresenta uma linha temporal de 25 anos, utilizando uma densidade de 278 plantas/ha e produção estimada no final do ciclo em 222,4 $\mathrm{m}^{3} /$ ha (média de 0,80 metros cúbicos/árvore). Nas grandes serrarias da região, 
esta espécie foi estimada em $\mathrm{R} \$ 50,00 \mathrm{~m}^{3} /$ tora. Com esta situação, o mogno poderia render R\$ 11.120,00/ha.

Para o referido estudo, considerou-se a madeira negociada em nível de produtor, utilizando desconto de $60 \%$ em relação ao valor de mercado $\mathrm{R} \$ 20,00 \mathrm{~m}^{3} /$ tora em pé. Adotando este critério, constatou-se que no período estabelecido, a produção do mogno rendeu ao sistema $\mathrm{R} \$ 4.448,00 /$ ha (Figura 10). Os custos apresentados no estabelecimento desta espécie referem-se às despesas no preparo das mudas ( $\mathrm{R} \$ 51,00)$, plantio (47,00), adubação ( $\mathrm{R} \$ 46,00)$, controle de poda $(\mathrm{R} \$ 45,00)$, replantio $(\mathrm{R} \$$ $43,00)$, poda $(\mathrm{R} \$ 38,00)$ e manutenção $(\mathrm{R} \$ 4,00)$.

Já para o componente teca é apresentado um horizonte de 15 anos, com densidade de 200 plantas/ha, com produção estimada no final do ciclo de 120 metros cúbicos/ha (média de $0,60 \mathrm{~m}^{3} /$ tora). Em nível de mercado o valor da espécie chega a $\mathrm{R} \$$ $80,00 \mathrm{~m}^{3}$ e, nestas condições, a madeira poderia render até $\mathrm{R} \$ 9.600,00 \mathrm{~m}^{3} / \mathrm{ha}$. Em nível do produtor, considerou-se desconto de $60 \%$ em relação ao valor de mercado $\mathrm{R} \$ 32,00$ $\mathrm{m}^{3} /$ madeira em pé.

Constatou-se que no período estabelecido, a produção da teca rendeu ao sistema R $\$ 3.840,00 \mathrm{~m}^{3} / \mathrm{ha}$. Os custos apresentados no estabelecimento da cultura da teca aplicam-se às atividades no preparo das mudas $(\mathrm{R} \$ 59,00)$, plantio $(\mathrm{R} \$ 58,00)$, poda $(\mathrm{R} \$ 53,00)$ e manutenção $(\mathrm{R} \$ 7,00)$.

Na cultura da mandioca, foi estabelecida uma densidade de 10.000 plantas/ha com produção média de 14 ton/ha (média de 1,4 kg de raiz fresca/planta). O período de estabelecimento da cultura foi igual ao do sistema AS1 (Figura 9). O valor do produto no mercado local foi estimado em $\mathrm{R} \$ 0,50 \mathrm{~kg}$ da raiz; em nível do produtor adotourse desconto de $60 \%$, fixando-se o valor do produto em $\mathrm{R} \$ 0,20 \mathrm{~kg} / \mathrm{raiz}$.

Em relação à produção dentro do sistema, chegouse a valores de R\$ 1.043,00/ha/ano, o que corresponde a $5.215 \mathrm{~kg} / \mathrm{ha} /$ ano na primeira colheita, $\mathrm{R} \$$ $460,00 / \mathrm{ha} /$ ano $(2.300 \mathrm{~kg} / \mathrm{ha} / \mathrm{ano})$ no segundo ano e $\mathrm{R} \$ 450,00 /$ ha no terceiro ano $(2.250$ $\mathrm{kg} / \mathrm{ha} / \mathrm{ano})$. Nos anos em que houve o estabelecimento da mandioca observou-se um decréscimo de até $44 \%$ da produção, valores esperados devido às exigências nutricionais desta cultura. 
Os custos das atividades envolvidas na cultura da mandioca foram atribuídos às despesas com preparo de mudas ( $\mathrm{R} \$ 36,00)$, plantio/replantio ( $\mathrm{R} \$ 2$ 280,00), adubação/colheita (R \$ 320,00 e R \$ 197,00) e somente colheita ( $\$$ \$ 83,00).

Para as culturas (gliricídia, columbrina, centrosema e mucuna), a avaliação dos benefícios desses componentes se deu em função apenas do seu uso como alimento complementar para o gado (forragem). Os custos apresentados no fluxo correspondem a atividades de preparo de mudas, plantio/replantio, poda e manutenção.

A castanha-do-brasil teve densidade de 100 plantas/ha e sua produção de ouriço está estimada em 30 ouriços/planta, sendo que cada ouriço produz aproximadamente (40 amêndoas e/ou castanha), o equivalente a 0,800 kg/frutos/ouriço. $\mathrm{O}$ valor do produto no mercado foi em média $\mathrm{R} \$ 1,20$ o quilo. O produto negociado em nível do produtor, utilizando desconto de $60 \%$ em relação ao valor de mercado, foi $\mathrm{R} \$$ $0,58 \mathrm{~kg} /$ fruto.

A primeira produção aconteceu no $12^{\mathrm{a}}$ obtendo uma produtividade de 396 $\mathrm{kg} /$ ha/ano $(\mathrm{R} \$ 230,00)$ quando, houve uma baixa de produtividade no ano seguinte $13^{\circ}$ ano, variando em torno de 14\%, ou seja, a produção ficou em $341 \mathrm{~kg} / \mathrm{ha}(\mathrm{R} \$ 198,00)$. Este nível foi mantido até o $20^{\circ}$ ano quando ocorreu uma nova queda na produção de $10 \%$, no $21^{\circ}$ ano $(\mathrm{R} \$ 178,00) 307 \mathrm{~kg} /$ ha permanecendo esta média até o final da cultura, ou seja, $146 \mathrm{~kg} / \mathrm{ha}(\mathrm{R} \$ 85,00)$. Os custos praticados no estabelecimento desta cultura foram destinados ao preparo das mudas ( $\mathrm{R} \$ 63,00$ ), plantio ( $\mathrm{R} \$ 54,00)$, adubação ( $\mathrm{R} \$$ $50,00)$, colheita $(R \$ 46,00)$ e em manutenção da área $(R \$ 8,00)$.

Para a espécie acerola, foi utilizada densidade de 400 plantas/ha e sua produção estimada a partir do 4 ano de plantio, com aproximadamente $12 \mathrm{~kg} /$ frutos/planta podendo produzir até 4.800 frutos. O preço de venda do produto no mercado foi em média $\mathrm{R} \$ 1,85 \mathrm{~kg} /$ fruto. O produto negociado em nível do produtor, utilizando desconto de $60 \%$ em relação ao valor de mercado, foi $\mathrm{R} \$ 0,74 \mathrm{~kg} /$ fruto.

Foi detectado nas três primeiras colheitas uma produção de $50 \mathrm{~kg} / \mathrm{ha}(\mathrm{R} \$$ $67,00), 124 \mathrm{~kg} / \mathrm{ha}(\mathrm{R} \$ 92,00)$ e $176 \mathrm{~kg} / \mathrm{ha}(\mathrm{R} \$ 130,00)$ respectivamente. A partir do $6^{\circ}$ ano ocorreu decréscimo de produção, mantendo-se em $\mathrm{R} \$$ 95,00 (128 kg/ha). Em nível de custos, praticou-se despesas tais como preparo das mudas (R\$ 127,00), plantio/replantio $(111,00)$, replantio $(\mathrm{R} \$ 105,00)$, poda $(\mathrm{R} \$ 100,00)$, colheita e poda em 
diferentes estágios ( $\mathrm{R}$ \$ 100,00), adubação/colheita ( $\mathrm{R}$ \$ 59,00) e manutenção/colheita $(\mathrm{R} \$ 4,00)$.

No estabelecimento do maracujá foi adotada densidade de 164 plantas/ha e sua produção estimada em $16 \mathrm{~kg} /$ frutos/planta, aproximadamente $2.624 \mathrm{~kg} /$ frutos/ha. $\mathrm{O}$ valor do produto no mercado foi em média $\mathrm{R} \$ 1,70 / \mathrm{kg}$. O produto negociado em nível do produtor, utilizando desconto de $60 \%$ em relação ao valor de mercado, foi $\mathrm{R} \$ 0,68$ $\mathrm{kg} /$ fruto.

Na primeira colheita, o maracujá teve produção de $203 \mathrm{~kg} / \mathrm{ha}(\mathrm{R} \$ 138,00)$, $1.366 \mathrm{~kg} / \mathrm{ha}(\mathrm{R} \$ 929,00), 463 \mathrm{~kg} / \mathrm{ha}(\mathrm{R} \$ 315,00)$ e $162 \mathrm{~kg} / \mathrm{ha}(\mathrm{R} \$ 110,00)$ do $5^{\circ}$ ao $8^{\circ}$ ano do estabelecimento da cultura. Os custos praticados no estabelecimento da cultura foram destinados ao preparo das mudas ( $\mathrm{R} \$ 206,00)$, plantio/replantio $(180,00)$, colheita/poda no quinto e sexto ano ( $\mathrm{R} \$ 177,00$ e $\mathrm{R} \$ 174,00)$, adubação ( $\mathrm{R} \$ 125,00)$, colheita e poda $(\mathrm{R} \$ 100,00)$ e somente colheita $(\mathrm{R} \$ 53,00)$.

Para o jenipapo, foi utilizado uma densidade de 800 plantas/ha e sua produção estimada a partir do sétimo ano de plantio em aproximadamente 14.000 frutos (média de 30 frutos/planta), podendo alcançar 40.000 frutos (50 frutos/plantas) no $10^{\circ}$ ano. A média de peso para cada fruto foi estimada em $0,280 \mathrm{~kg} /$ fruto.

$\mathrm{O}$ preço de venda do produto no mercado foi de $\mathrm{R} \$ 0,70 \mathrm{~kg} /$ fruto. $\mathrm{O}$ estudo considerou o produto negociado em nível do produtor com um desconto de $60 \% \mathrm{em}$ relação ao valor de mercado, resultando em $\mathrm{R} \$ 0,28 \mathrm{~kg} /$ fruto.

No sistema, constatou-se que na primeira colheita o jenipapo produziu 714 $\mathrm{kg} / \mathrm{ha}(\mathrm{R} \$ 200,00)$, tendo na segunda colheita uma queda de $10 \%$ na produção que rendeu ao sistema ( $\mathrm{R} \$ 180,00), 642 \mathrm{~kg} / \mathrm{ha}$ mantendo até $17^{\circ}$ ano quando houve baixa de $14 \%$ na produção chegando ao volume de $553 \mathrm{~kg} / \mathrm{ha}(\mathrm{R} \$ 155,00)$. A partir deste período, o sistema apresentou estabilidade até o $18^{\circ}$ ano quando ocorreu baixa na produção de (33\%) ou seja $\mathrm{R}$ 104,00 (371 kg/ha) até seu estabelecimento final.

Os custos apresentados destinam-se às atividades como preparo das mudas $(\mathrm{R} \$$ 127,00), plantio ( $R$ \$ 88,00), replantio $(\mathrm{R} \$ 46,00, \quad \mathrm{R} \$ 25,00$ e $\mathrm{R} \$ 23,00)$ e manutenção/colheita $(\mathrm{R} \$ 4,00)$.

Na cultura do araçá-boi foi usada uma densidade de 278 plantas/ha, com uma apropriação da área em torno de $8 \%$ e produção estimada a partir do segundo ano de plantio em aproximadamente 4.170 frutos (média de 15 frutos/planta), podendo alcançar 
7.784 frutos (28 frutos/plantas) no $10^{\circ}$ ano. A média de peso de cada fruto foi estimada em $0,110 \mathrm{~kg} /$ fruto e o horizonte para esta espécie foi estimado em 15 anos.

O preço de venda do produto no mercado foi de $\mathrm{R} \$ 0,65 / \mathrm{kg}$ de fruto. Em nível do produtor, considerou-se um desconto de $60 \%$ em relação ao valor de mercado ( $\mathrm{R} \$$ $0,28 / \mathrm{kg} /$ fruto).

No referido sistema, constatou-se que nas primeiras colheitas a espécie araçáboi produziu $107 \mathrm{~kg} / \mathrm{ha}(\mathrm{R} \$ 30,00), 186 \mathrm{~kg} / \mathrm{ha}(\mathrm{R} \$ 52,00)$ e $207 \mathrm{~kg} / \mathrm{ha}(\mathrm{R} \$ 58,00)$ respectivamente. No sexto ano, observa-se uma pequena baixa na produção (6\%) até o $17^{\circ}$ período, tornando-se estável até o estabelecimento final da cultura.

Os custos referenciados à cultura destinamse a atividades como preparo das mudas ( $\mathrm{R} \$$ 70,00), plantio ( $\mathrm{R} \$$ 54,00), replantio/colheita $(\mathrm{R} \$ 46,00)$ e manutenção/colheita $(\mathrm{R} \$ 8,00)$. 


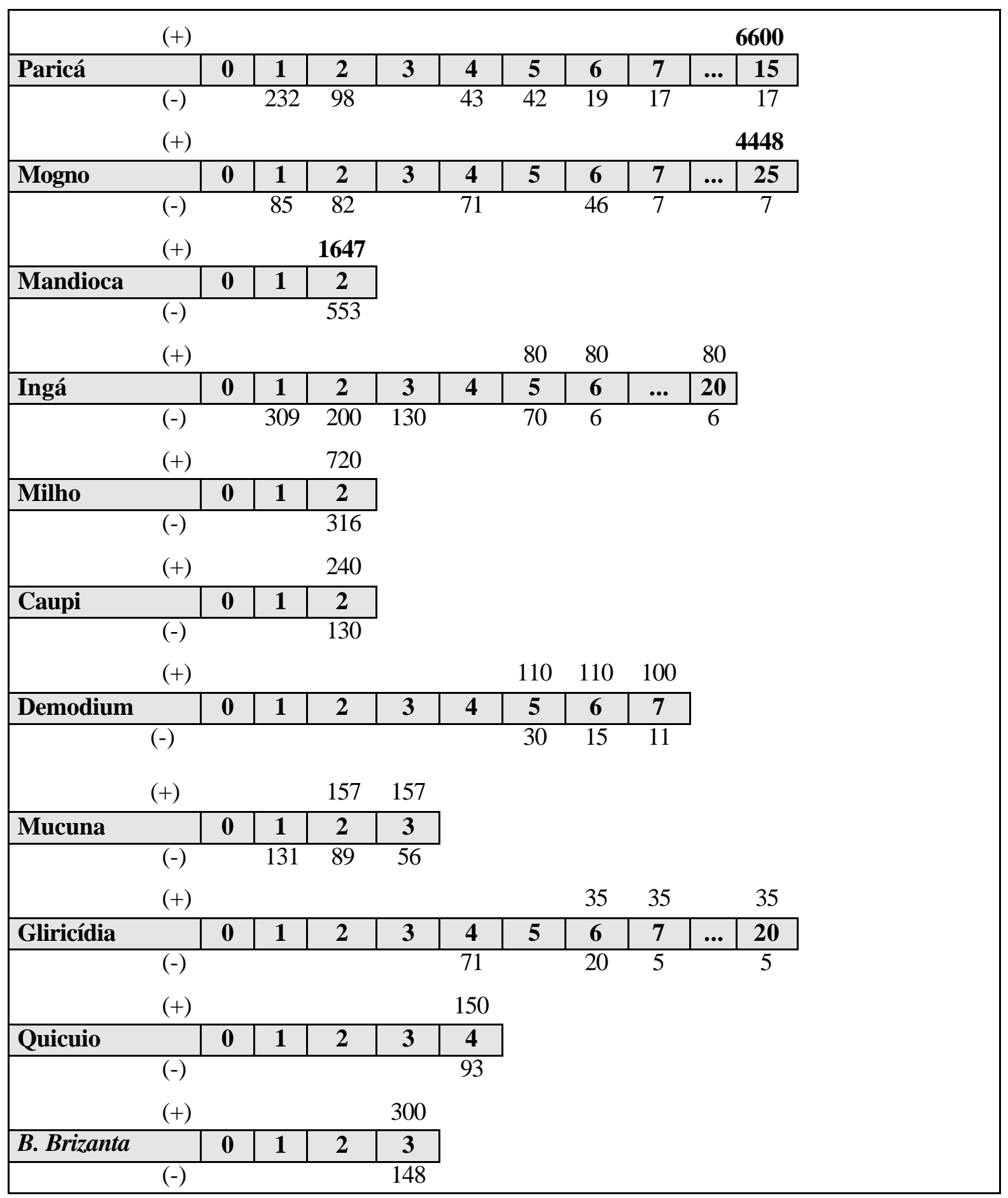

Figura 11 - Representação do fluxo de caixa no sistema ASP1 
No fluxo de caixa do sistema agrossilvipastoril, o componente madeireiro paricá apresenta uma linha de tempo de 15 anos, utilizando uma densidade de 2.500 plantas/ha, com uma apropriação da área em torno de $82 \%$ e produção prevista no final do ciclo em $1.375 \mathrm{~m}^{3} /$ ha de madeira em pé (média de 0,55 metros cúbicos/árvore). Nos grandes centros consumidores, esta espécie foi cotada em $\mathrm{R} \$ 12,00 \mathrm{~m}^{3} /$ madeira em pé, podendo render até $\mathrm{R} \$ 16.500,00 \mathrm{~m}^{3} / \mathrm{ha}$.

Para o referido estudo, a madeira negociada em nível de produtor foi calculada utilizando desconto de $60 \%$ em relação ao valor de mercado que é $\mathrm{R} \$ 4,80 \mathrm{~m}^{3} /$ tora em pé. Pelo critério adotado, constatourse que no período estabelecido, a produção da madeira rendeu ao sistema $\mathrm{R} \$ 6.600,00 \mathrm{~m}^{3} /$ tora/ha (Figura 11). Os custos apresentados no estabelecimento da espécie correspondem às despesas no preparo das mudas $(\mathrm{R} \$$ $232,00)$, plantio ( $\mathrm{R} \$ 98,00)$, adubação $(\mathrm{R} \$ 43,00)$ replantio ( $\mathrm{R} \$ 42,00)$, desbaste $(\mathrm{R} \$$ $19,00)$ e manutenção $(\mathrm{R} \$ 17,00)$.

O mogno apresenta um horizonte semelhante aos adotados nos demais sistemas (25 anos), utilizando uma densidade de 278 plantas/ha e produção estimada no final do ciclo em 222,4 $\mathrm{m}^{3} /$ ha (média de 0,80 metros cúbicos/árvore). Nas grandes serrarias da região (Manaus), esta espécie foi estimada em $\mathrm{R} \$ 50,00 \mathrm{~m}^{3} /$ tora. Com esta situação, o mogno poderia render $\mathrm{R} \$ 11.120,00 /$ ha.

Para o referido estudo, considerou-se a madeira negociada em nível de produtor utilizando o desconto de $60 \%$ em relação ao valor de mercado que é $\mathrm{R} \$ 20,00$ $\mathrm{m}^{3} /$ tora em pé. Adotando este critério, constatou-se que no período estabelecido, a produção do mogno rendeu ao sistema $\mathrm{R} \$ 4.448,00 / \mathrm{ha}$.

Os custos apresentados no estabelecimento desta espécie foram empregadas nas atividades como preparo das mudas $(\mathrm{R} \$ 85,00)$, plantio $(\mathrm{R} \$ 82,00)$, adubação/poda $(\mathrm{R} \$ 71,00)$ replantio $(\mathrm{R} \$ 46,00)$ e manutenção $(\mathrm{R} \$ 7,00)$.

Para a cultura da mandioca foi estabelecida uma densidade igual a do sistema AS2 (10.000 plantas/ha) com produção média de 14 toneladas de raiz fresca/ha (média de $1,4 \mathrm{~kg} /$ planta). O período de estabelecimento da cultura foi diferenciado dos demais sistemas (somente uma rotação). O valor do produto no mercado local foi igual aos demais ( $\mathrm{R} \$ 0,50 / \mathrm{kg}$ ), adotando-se desconto em nível do produtor de 60\%, fixando-se o valor do produto em $\mathrm{R} \$ 0,20 \mathrm{~kg} / \mathrm{raiz}$. 
A receita com a cultura da mandioca, estimada em $\mathrm{R} \$ 1.647,00 /$ ha resultado da venda da produção observada no experimento. Essa produção foi de $8.235 \mathrm{~kg} / \mathrm{ha}$, valor este bastante inferior aos $14.000 \mathrm{~kg} / \mathrm{ha}$ que seriam esperados em monocultivos com densidade de 10.000 plantas/ha. O uso de um valor de produção baixo se deve à presuposição de que os SAFs propostos implantados em áreas degradadas não respondem a baixa fertilidade do solo. Os custos das atividades usadas na cultura da mandioca foram atribuídos a despesas como preparo de mudas, plantio e colheita $(\mathrm{R} \$$ $553,00)$.

Para as culturas (gliricídia, columbrina, centrosema e mucuna), a avaliação dos benefícios desses componentes se deu em função apenas do seu uso como alimento complementar para o gado (forragem). Os custos apresentados no fluxo correspondem a atividades de preparo de mudas, plantio/replantio, poda e manutenção.

O milho foi utilizado somente em uma rotação, com uma densidade de 15.000 plantas/ha e produção média de 11 ton/ha (média de $1,36 \mathrm{~kg} /$ planta). O período de plantio foi semelhante ao da mandioca $\left(3^{\circ}\right.$ ano). $\mathrm{O}$ valor do produto no mercado local foi estimado em ( $\mathrm{R} \$ 0,60 \mathrm{~kg})$, adotando-se desconto em nível do produtor de $60 \%$, o valor foi fixando em $\mathrm{R} \$ 0,24$ o quilo.

Com relação à produção dentro do sistema, obteve-se valores de $\mathrm{R} \$ 720,00$ ha/ano o que corresponde a $3.000 \mathrm{~kg} / \mathrm{ha} / \mathrm{ano}$. Os custos das atividades utilizadas para o milho foram atribuídos ao plantio, controle e colheita $(\mathrm{R} \$ 316,00)$.

O feijão caupi foi adotado somente para uma produção, com densidade de 66.400 plantas/ha e produção média de 2 ton/ha (média de $748 \mathrm{~kg} / \mathrm{ha}$ ). O período de plantio foi semelhante ao do milho ( $3^{\circ}$ ano). $\mathrm{O}$ valor do produto no mercado local foi estimado em $\mathrm{R} \$ 0,65 \mathrm{~kg}$ e adotando-se desconto em nível do produtor de $60 \%$, o valor foi fixado em $\mathrm{R} \$ 0,26 \mathrm{~kg}$.

A produtividade no sistema chegou a $\mathrm{R} \$ 240,00$ ha/ano, o que corresponde a (923 kg/ha). O custo de R \$ 130,00 foi atribuído às atividades de plantio e colheita. 


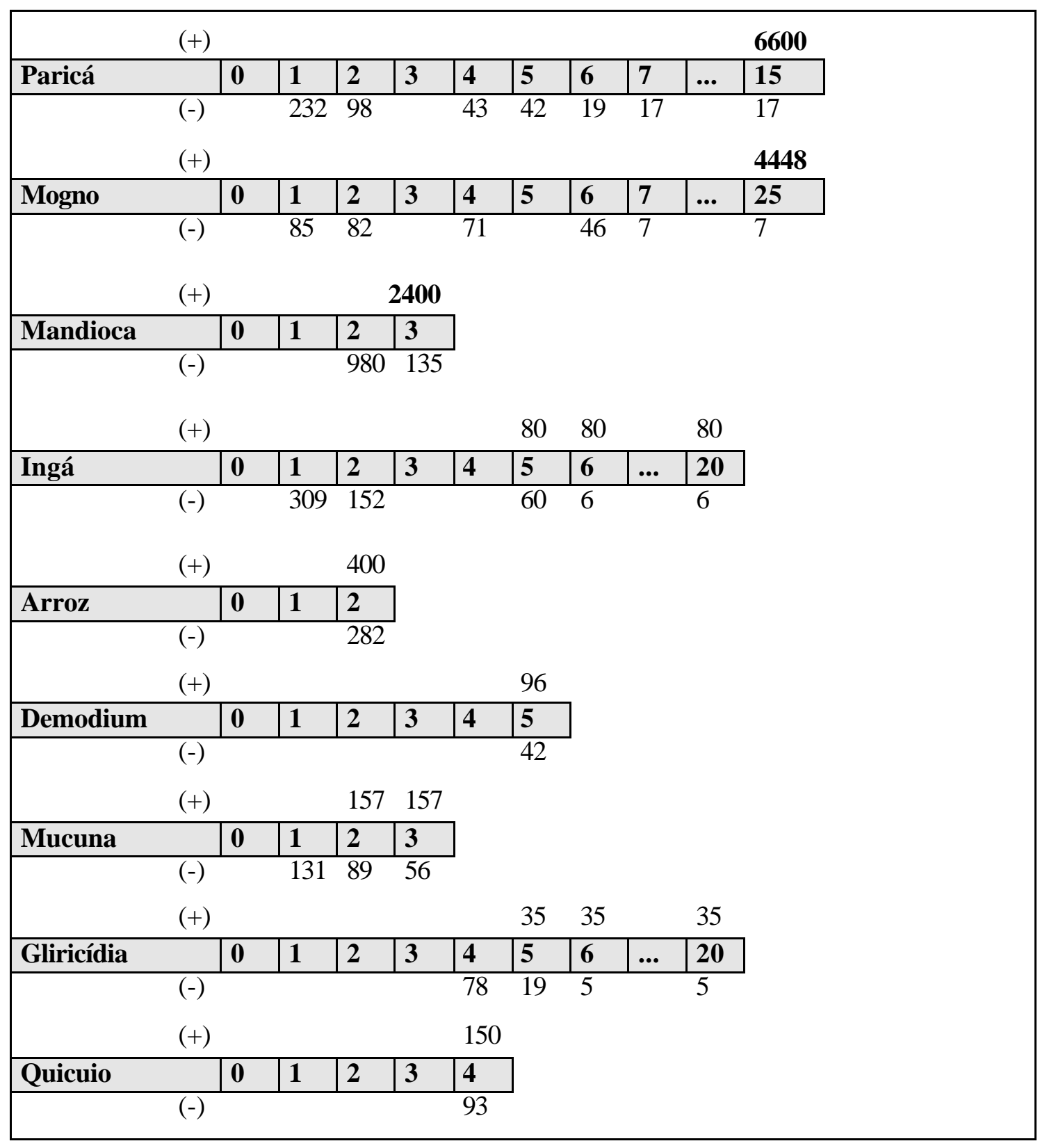

Figura 12 - Representação do fluxo de caixa no sistema ASP2

No fluxo de caixa do sistema agrossilvipastoril, a espécie paricá apresenta um horizonte temporal de 15 anos, utilizando a mesma densidade do sistema ASP1 (2.500 plantas/ha), com uma apropriação da área em torno de $82 \%$ e produção prevista no final do ciclo em $1.375 \mathrm{~m}^{3} /$ ha de madeira em pé (média de 0,55 metros cúbicos/árvore). $\mathrm{O}$ 
valor desta espécie foi estimado em $\mathrm{R} \$ 12,00 \mathrm{~m}^{3} /$ madeira em pé. Nestas condições, o paricá pode render até $\mathrm{R} \$ 16.500,00 \mathrm{~m}^{3} / \mathrm{ha}$.

Para o referido estudo, a madeira negociada em nível de produtor foi calculada utilizando desconto de $60 \%$ em relação ao valor de mercado que é $\mathrm{R} \$ 4,80 \mathrm{~m}^{3} /$ tora em pé. Pelo critério adotado, constatourse que no período estabelecido, a produção da madeira rendeu ao sistema $\mathrm{R} \$ 6.600,00 \mathrm{~m}^{3} /$ tora/ha (Figura 12).

Os custos apresentados no estabelecimento da espécie correspondem às despesas no preparo das mudas $(\mathrm{R} \$ 232,00)$, plantio $(98,00)$, adubação ( $\mathrm{R} \$ 43,00)$ replantio ( $R$ \$ 42,00), desbaste $(R \$ 19,00)$ e manutenção $(R \$ 7,00)$.

O mogno apresenta também um horizonte temporal semelhante aos demais sistemas (25 anos), utilizando uma densidade de 278 plantas/ha e área de apropriação em torno de $10 \%$, com produção estimada no final do ciclo em $222,4 \mathrm{~m}^{3} /$ ha (média de 0,80 metros cúbicos/árvore). Na região, esta espécie foi estimada em $\mathrm{R} \$ 50,00$ $\mathrm{m}^{3} /$ madeira em pé. Nesta situação, o mogno poderia render em torno de $\mathrm{R} \$$ $11.120,00 / \mathrm{ha}$.

Para o referido estudo foi considerado a madeira negociada na propriedade utilizando desconto de $60 \%$ em relação ao valor de mercado, ou seja, com um preço de $\mathrm{R} \$ 20,00 \mathrm{~m}^{3} /$ madeira em pé. Com este critério, constatou-se que no período de estabelecimento, a produção do mogno rendeu ao sistema $\mathrm{R} \$ 4.448,00 /$ ha. Os custos apresentados aplicam-se a atividades como preparo das mudas ( $\mathrm{R} \$ 85,00)$, plantio $(\mathrm{R} \$$ 82,00), adubação/poda $(\mathrm{R} \$ 71,00)$ replantio $(\mathrm{R} \$ 46,00)$ e manutenção $(\mathrm{R} \$ 7,00)$.

Para a cultura da mandioca, foi estabelecida uma densidade igual a do sistema ASP1 (10.000 plantas/ha), com produção média estimada em 14 ton/raiz fresca/ha (média de 1,4 kg/planta). O período estabelecido da cultura foi diferenciado dos demais sistemas (somente uma rotação). O valor do produto no mercado local foi igual aos demais (R\$ 0,50 kg/raiz), adotando-se desconto em nível do produtor de 60\%, o que fixa o produto em $\mathrm{R} \$ 0,20 \mathrm{~kg} / \mathrm{raiz}$ fresca.

Em relação à produção dentro do sistema, chegoułse a valores de $R \$$ $2.400,00 / \mathrm{ha}$, o que corresponde a $12.000 \mathrm{~kg} / \mathrm{ha} / \mathrm{ano}$. Os custos de $\mathrm{R} \$ 980,00$ para a mandioca foram atribuídos a atividades como preparo das mudas/plantio R \$ 135,00 usado para a colheita. 
$\mathrm{O}$ arroz foi incorporado ao sistema utilizando a mesma densidade dos demais modelos (100.000 plantas/ha e 2,6 ton/ha). A cultura foi estabelecida somente por um ano. $\mathrm{O}$ valor do produto no mercado foi estimado em $\mathrm{R} \$ 0,85 \mathrm{~kg}$, considerando-se o desconto de $60 \%$, com o produtor o arroz é negociado a $\mathrm{R} \$ 0,32 \mathrm{~kg}$.

No referido sistema, a produtividade do arroz foi de $1.250 \mathrm{~kg} / \mathrm{ha} / \mathrm{ano}$, com rentabilidade de $\mathrm{R} \$$ 400,00/ha/ano. Os custos desta cultura são atribuídos as atividades como, plantio, adubação e colheita ( $\mathrm{R}$ \$ 282,00).

Para as culturas que foram utilizadas tendo como principal atividade o aumento da biomassa no solo, cerca viva, pastagem e produção de lenha (ingá, desmódium, mucuna, glirícidia quicuio), foram estimados valores agregados à terra, para tal, são observados valores fixos de receitas para estas espécies. Os custos apresentados no fluxo destinam-se às atividades de preparo de mudas, plantio/replantio, poda e controle. 


\subsection{Avaliação econômica dos SAFs}

As análises de rentabilidade dos sistemas agroflorestais utilizadas no experimento foram realizadas a partir dos respectivos fluxos de caixa (Figuras 9 a 12).

Nas Tabelas 8, 9, 10 e 11, é apresentado o desempenho econômico medido pelo critério do valor presente de cada SAF. Nota-se que o sistema AS1 apresenta valores do VET negativos nos componentes perenes (columbrina e gliricídia) quando empregados juros de 9 e $12 \%$ ao ano.

Tabela 8. Rentabilidade econômica.

\begin{tabular}{|c|c|c|c|}
\hline "Sistema: AS1 & \multicolumn{3}{|c|}{ Taxas utilizadas (\%) } \\
\hline Componentes & \multicolumn{3}{|c|}{ VPs $(\%)$} \\
\hline & $\overline{6}$ & 9 & $\overline{12}$ \\
\hline Arroz & 62,00 & 59,00 & 56,00 \\
\hline Centrosema & 5,11 & 4,30 & 4,00 \\
\hline Mandioca & 276,00 & 236,00 & 200,00 \\
\hline Mucuna & 24,00 & 22,00 & 20,00 \\
\hline Valor & 367,11 & 312,0 & 280,00 \\
\hline $\begin{array}{l}\text { Componentes } \\
\text { Perenes }\end{array}$ & \multicolumn{3}{|c|}{ VETs $(\%)$} \\
\hline & 6 & 9 & 12 \\
\hline Açaí & $1.017,00$ & 440,00 & 163,00 \\
\hline Columbrina & 27,00 & $-3,40$ & $-18,00$ \\
\hline Cupuaçu & $3.877,00$ & $2.230,00$ & $1.396,00$ \\
\hline Gliricídia & 3,00 & $-112,00$ & $-116,00$ \\
\hline Pupunha fruto & $1.070,00$ & 557,00 & 300,00 \\
\hline Pupunha palmito & 369,00 & 163,00 & 58,00 \\
\hline
\end{tabular}

\begin{tabular}{cccc}
\hline \hline Valor & $6.363,00$ & $2.275,00$ & $1.819,00$ \\
\hline Valor sistema & $6.730,11$ & $2.587,00$ & $2.099,00$ \\
\hline
\end{tabular}

Fonte: Dados da pesquisa
Tabela 9. Rentabilidade econômica.

\begin{tabular}{|c|c|c|c|}
\hline Sistema: AS2 & \multicolumn{3}{|c|}{ Taxas utilizadas (\%) } \\
\hline Componentes & \multicolumn{3}{|c|}{ VPs (\%) } \\
\hline & $\overline{6}$ & 9 & $\overline{12}$ \\
\hline Arroz & 31,00 & 30,00 & 29,00 \\
\hline Centrosema & 79,00 & 66,00 & 55,00 \\
\hline Mandioca & 854,00 & 778,00 & 710,00 \\
\hline Mucuna & 23,00 & 12,00 & 2,00 \\
\hline Valor & 987,00 & 886,00 & 796,00 \\
\hline $\begin{array}{c}\text { Componentes } \\
\text { Perenes } \\
\end{array}$ & \multicolumn{3}{|c|}{ VETs (\%) } \\
\hline & 6 & 9 & 12 \\
\hline Acerola & 385,00 & 154,00 & 97,00 \\
\hline Araçá-boi & 413,00 & 237,00 & 147,00 \\
\hline Cast.Brasil & 882,00 & 450,00 & 208,00 \\
\hline Cupuaçu & 2553,00 & $1.379,00$ & 789,00 \\
\hline Gliricídia & 448,00 & 110,00 & 58,00 \\
\hline Ingá & 310,00 & 161,00 & 6,00 \\
\hline Jenipapo & $1.350,00$ & 744,00 & 438,00 \\
\hline Maracujá & 393,00 & 330,00 & 44,00 \\
\hline Mogno & $1.004,00$ & 304,00 & 41,00 \\
\hline Teca & $2.389,00$ & $1.184,00$ & 633,00 \\
\hline Valor & $\mathbf{0 . 1 2 7 , 0 0}$ & $5.053,00$ & $2.461,00$ \\
\hline Val or sistema & 11.114,00 & $5.939,00$ & $3.416,00$ \\
\hline
\end{tabular}

Fonte: Dados da pesquisa 
Analisando-se as culturas agrícolas anuais dos sistema AS1 e AS2 (Tabela 8 e 9), o cultivo da mandioca nos modelos testados foi o mais rentável para as taxas de juros empregadas. Dos modelos que adotaram o cultivo de mandioca, o sistema ASP2 foi o que apresentou uma receita superior aos demais sistemas envolvidos seguido do ASP1. A razão do ganho na utilização desta cultura está relacionada com o espaçamento adotado (Tabelas 6 e 7). A diferença da rentabilidade dos sistemas foi causada pelas substituições de algumas mudas de mandioca no sistema ASP1, enquanto que para o ASP2 essa atividade não foi conduzida.

Analisando-se a rentabilidade dos sistemas agrossilvipastoril (Tabelas 10 e 11), o componente perene ingá foi introduzido no sistema com o objetivo de servir como complemento alimentar para o gado e aumento de biomassa no solo, o que provavelmente poderia diminuir os custos na aquisição de silagem e na aplicação de insumos, já que os resíduos derivados da poda serviriam como adubo verde. No entanto, os custos de preparo das mudas, plantio e manutenção desta espécie foram maiores do que a economia que seria feita com aquisição de silagem e insumos, o que explica a baixa rentabilidade observada a taxas de 9 e $12 \%$ no sistema ASP1 e a $12 \%$ no sistema ASP2. Além disto, esta espécie não apresenta valor de atratividade no mercado, sendo utilizada prioritariamente para a atração de dispersores de sementes, aumento de biomassa no solo, produção de lenha e servindo como cerca viva.

Outra explicação para o desempenho econômico positivo no sistema ASP2, baseia-se no fato de que este componente não sofreu aplicação de insumos na aquisição do sistema (Tabela 11), enquanto que no ASP1 houve aplicação de insumos gerando um custo maior no momento da implantação (Figuras 11 e 12). 
Tabela 10. Rentabilidade econômica. econômica.

\begin{tabular}{|c|c|c|c|}
\hline Sistema: & \multicolumn{3}{|c|}{ Taxas utilizadas (\%) } \\
\hline $\begin{array}{l}\text { Componentes } \\
\text { Agrícolas anual }\end{array}$ & \multicolumn{3}{|c|}{$\operatorname{VPs}(\%)$} \\
\hline & $\overline{6}$ & 9 & 12 \\
\hline B.brizanta & 120,00 & 108,00 & 97,00 \\
\hline Desmodium & 169,00 & 84,00 & 44,00 \\
\hline Feijão & 98,00 & 93,00 & 88,00 \\
\hline Mandioca & 974,00 & 921,00 & 872,00 \\
\hline Milho & 319,00 & 302,00 & 286,00 \\
\hline Mucuna & 69,00 & 66,00 & 62,00 \\
\hline Quicui & 45,00 & 40,00 & 36,00 \\
\hline Valor & $1.794,00$ & $1.614,00$ & $1.485,00$ \\
\hline $\begin{array}{c}\text { Componentes } \\
\text { Perenes }\end{array}$ & \multicolumn{3}{|c|}{$\operatorname{VETs}(\%)$} \\
\hline & 6 & 9 & 12 \\
\hline Gliricídia & 219,00 & 119,00 & 70,00 \\
\hline Ingá & 106,00 & $-70,00$ & $-158,00$ \\
\hline Mogno & 964,00 & 287,00 & 27,00 \\
\hline Paricá & $3.900,00$ & $1.898,00$ & 988,00 \\
\hline Valor & $5.189,00$ & $2.234,00$ & 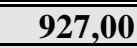 \\
\hline Valor do sistema & $6.983,00$ & $3.848,00$ & $2.412,00$ \\
\hline
\end{tabular}

Fonte: Dados da pesquisa
Tabela $\quad 11 . \quad$ Rentabilidade

\begin{tabular}{|c|c|c|c|}
\hline \multirow{2}{*}{$\begin{array}{l}\text { Sistema: } \\
\text { ASP2 } \\
\text { Componentes } \\
\text { Agrícolas anual }\end{array}$} & \multicolumn{3}{|c|}{ Taxas utilizadas (\%) } \\
\hline & \multicolumn{3}{|c|}{$\operatorname{VPs}(\%)$} \\
\hline & 6 & 9 & 12 \\
\hline Arroz & 105,00 & $\begin{array}{l}99,00 \\
\end{array}$ & 94, \\
\hline Desmodium & 169,00 & 84,00 & 44, \\
\hline Mandioca & $1.030,00$ & 924,00 & 831,0 \\
\hline Mucuna & 56,00 & 54,00 & \\
\hline Quicuio & 40,00 & 35,00 & 31,0 \\
\hline
\end{tabular}

\begin{tabular}{crrr}
\hline Valor & $\mathbf{1 . 4 0 0 , 0 0}$ & $\mathbf{1 . 1 9 6 , 0 0}$ & $\mathbf{1 . 0 5 3 , 0 0}$ \\
\hline $\begin{array}{c}\text { Componentes } \\
\text { Perenes }\end{array}$ & \multicolumn{3}{c}{ VETs $(\%)$} \\
\hline \multicolumn{1}{c}{$\mathbf{6}$} & \multicolumn{1}{c}{$\mathbf{9}$} & \multicolumn{1}{|c}{} \\
\hline Gliricídia & 176,00 & 88,00 & 46,00 \\
Ingá & 239,00 & 24,00 & $-83,00$ \\
Mogno & $1.121,00$ & 355,00 & 60,00 \\
Paricá & $3.666,00$ & $1.782,00$ & 927,00 \\
\hline \hline Valor & $\mathbf{5 . 2 0 2 , 0 0}$ & $\mathbf{2 . 2 4 9 , 0 0}$ & $\mathbf{9 5 0 , 0 0}$ \\
\hline Valor do sistema & $\mathbf{6 . 6 0 2 , 0 0}$ & $\mathbf{3 . 4 4 5}$ & $\mathbf{2 . 0 0 3 , 0 0}$ \\
\hline \hline
\end{tabular}

Fonte: Dados da pesquisa

Os demais componentes (gliricídia, paricá e teca) das Tabelas 10 e 11 apresentaram rentabilidade positiva, compensando o prejuízo gerado pelo componente ingá. O cenário apresentado por estas espécies justifica seu uso dentro do sistema uma vez que proporcionam ao produtor um rendimento superior ao custo de oportunidade de capital 


\subsection{Viabilidade econômica dos modelos agroflorestais testados}

De maneira geral, o estudo de viabilidade econô mica mostrou que os sistemas agroflorestais apresentaram rentabilidade positiva, sendo que o sistema AS2 destaca-se em relação aos demais sistemas devido a quantidade de espécies com grande aceitação no mercado local, e devido a sua continuidade produtiva de média a longo prazo (Figura 13). Nota-se que os sistemas apresentam viabilidade econômica para a pratica.

\section{Viabilidade econômica dos SAFs utilizando os critérios de avaliação.}

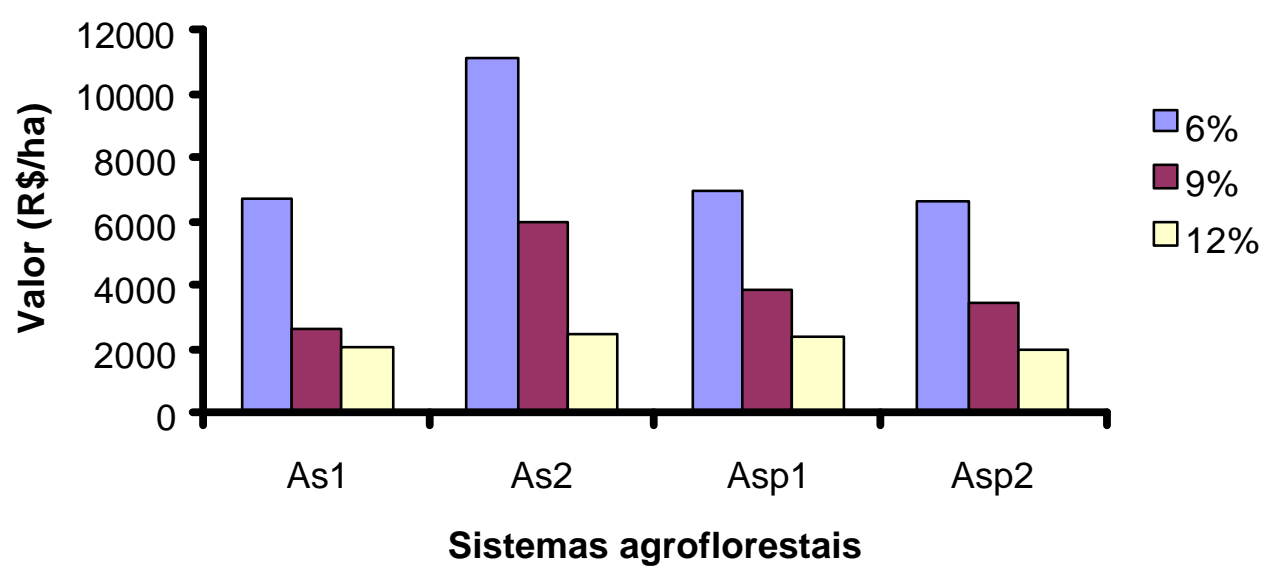

Figura 13 - Desempenho econômico dos sistemas agroflorestais da E.E.Embrapa-CPPA, Amazônia Ocidental - DAS.

Utilizando os critérios de avaliação de projetos, nota-se que todos os sistemas agroflorestais observados apresentam VPL positivo, portanto todos os modelos podem ser recomendados para serem aplicados na recuperação de áreas degradadas nas condições em que encontram-se a área de estudo. Como exposto na Figura 13, o VPL decresce à medida em que a taxa de desconto aumenta. 


\subsection{Comparação entre sistemas consorciados e monocultivo}

No Brasil, especialmente nos últimos anos, além do aumento da conscientização da sociedade sobre a importância da preservação ambiental, vêm sendo executados vários programas de pesquisa e ações visando a conservação e o aumento da cobertura florestal. Estas iniciativas envolvem atividades de preservação e recuperação de matas ciliares e/ou recuperação de áreas degradadas, plantios de maciços florestais, monocultivos e/ou através da implantação de sistemas agroflorestais.

Além dos vários benefícios ambientais, econômicos e sociais, os plantios

solteiros e/ou consorciados de espécies florestais madeireiras e não-madeireiras contribuem para o atendimento da portaria do IBAMA $\mathrm{n}^{\circ} 441$, de 09/08/89, que determina a reposição de áreas florestais exploradas.

Mesmo com todos os benefícios gerados por plantios consorciados ou não em nível de produtor, ainda persiste a falta de informações principalmente sobre a rentabilidade econômica desses plantios.

Para uma comparação da produção média das culturas consorciadas utilizadas com a produção em sistemas de monocultivo foi preparada a Tabela 12 envolvendo 62 municípios do Estado do Amazonas. 
Tabela 12. Comparação produtiva entre sistemas de monocultivo e sistemas consorciados.

\begin{tabular}{|c|c|c|c|c|c|}
\hline \multicolumn{2}{|c|}{ Monocultivo } & \multicolumn{4}{|c|}{ Plantio consorciado - SAF } \\
\hline Produto & $\begin{array}{c}\text { Produtividade } \\
\text { kg/ha }\end{array}$ & \multicolumn{4}{|c|}{ Produtividade (kg/ha) } \\
\hline & & $\overline{\text { AS1 }}$ & AS2 & ASP1 & ASP2 \\
\hline Açaí $^{(*)}$ & 3.137 & 7.193 & - & - & - \\
\hline Acerola & 8.571 & - & 1.231 & - & - \\
\hline Araçá-boi & 800 & - & 1.500 & - & - \\
\hline Arroz & 2.637 & 1.857 & 1.104 & - & 1.590 \\
\hline Cupuaçu ${ }^{(* *)}$ & 2.108 & 6.320 & 12.452 & - & - \\
\hline Feijão & 803 & - & - & 405 & - \\
\hline Jenipapo & 1.110 & & 7.452 & & \\
\hline Mandioca & 3.013 & 2.483 & 3.255 & 2.930 & 2.400 \\
\hline Maracujá $^{(* *)}$ & 890 & - & 2.458 & - & - \\
\hline Milho & 1.867 & - & - & 2.193 & - \\
\hline Palmito & 2.100 & 2.413 & - & - & - \\
\hline Pupunha $^{(*)}$ & 1.538 & 3.113 & & & \\
\hline
\end{tabular}

Fonte: IDAM, ISAE, Embrapa/CPPA, (1997). (*) cacho, $\left(^{* *}\right)$ frutos

Observa-se que as culturas consorciadas a produtividade em algumas situações foram superiores ao sistema monocultivo (Tabela 12). Comparativamente, das culturas consorciadas, a que mais se aproximou do sistema do monocultivo foi a mandioca, pois este cultivar tem baixa vulnerabilidade aos riscos climáticos que, freqüentemente, causam perdas consideráveis a outras culturas anuais.

Com relação as culturas perenes dentro dos SAFs comparadas a monocultivo, somente a espécie acerola não apresentou resultado superior ao monocultivo. A razão está atribuída principalmente à forma de ocupação da área.

Nota-se que a consorciação destes sistemas pode favorecer o mutualismo e conseqüentemente uma maior produtividade dos SAFs quando comparadas à produtividade obtida nessas áreas degradadas. 


\section{CONCLUSÕES}

A evolução dos modelos atuais de agricultura para sistemas mais intensivos de uso da terra ocorre de forma gradativa, sem grandes modificações no sistema tradicional. O sucesso de um sistema agroflorestal vai depender primeiramente da capacitação do agricultor em termos de manejo alternativo de praticar culturas de subsistência e comerciais.

Este estudo analisou a viabilidade econômica de sistemas agroflorestais visando restabelecer áreas que foram degradadas e abandonadas pela atividade pecuária na Amazônia. Para tanto, foram analisados quatro sistemas implantados na Estação Experimental da Embrapa/CPAA-DAS, Manaus.

De acordo com os resultados apresentados neste estudo conclui-se que:

1) Os sistemas agroflorestais analisados mostraram-se economicamente viáveis, indicando que este tipo de atividade pode ser utilizada como alternativa para a regeneração de áreas com níveis de degradação semelhantes aos observados no estudo de caso e como uma forma de atividade econômica para os agricultores da região. A análise do valor presente líquido para as produtividades, taxas de juros receitas e custos considerados, revelou que todos os modelos envolvidos no experimento podem apresentar resultados positivos.

2) Dentre os modelos propostos, o sistema agrossilvicultural multiestrato (AS2) apresentou melhor desempenho em relação aos demais. A razão para tal destaque deste sistema deve-se ao grande potencial comercial de espécies adotadas, das quais $71 \%$ possuem mercado garantido na região, e o restante $29 \%$, foram utilizadas como forrageira. 
3) Comparando a cultura solteira (monocultivo) em relação à consorciada (SAFs), seguindo levantamento da literatura quanto a produção, a segunda apresentourse favorável quanto a produtividade, dependendo de um manejo adequado, os SAFs poderão superar os resultados do monocultivo.

4) Adoção de sistemas agroflorestais pode promover um fluxo de caixa mais regular aos agricultores e oferece simultaneamente uma variedade de produtos madeireiros e não-madeireriros, permitindo ao agricultor maior flexibilidade na comercialização e racionalização da mão-de-obra familiar. 


\section{REFERÊNCIAS BIBLIOGRÁFICAS}

ALMEIDA, M. V. C.; SOUZA, V. F.; COSTA, R. S. C.; VIEIRA, A. H.; RODRIGUES, A. N. A.; COSTA, J. N. M.; RAM, A.; SÁ, C. P.; VENEZIANO, W.; JUNIOR, R. S. M. Sistemas Agroflorestais como alternativa autosustentável para o Estado de Rondônia. Porto Velho: PLANAFLORO; PNUD, 1995. 59p.

ALVIM, P. T. Agricultura e ecologia na Amazônia. Silvicultura, v.18, n.70, p.2730, 1997.

ANDERSON, S.; BIDWELL, T. G.; ROMANN, L. Introduction to agroforestry alternatives. Stillwater: Oklahoma State University, Extension Service, 1991. $12 \mathrm{p}$.

ANDRADE, R.P. Pastagens na região dos cerrados. In: CONGRESSO BRASILEITO DE PASTAGENS; SIMPÓSIO SOBRE MANEJO DE PASTAGEM, 8., Piracicaba, 1986. Anais. Piracicaba: FEALQ, 1986. p.455480 .

ANDRADE, R.P.; LEITE, G.G. Pastagens na região dos cerrados. Informe Agropecuário, v.13, n.153/154, p.26-39, 1988.

ARIMA, E.; UHL, C. Pecuária na Amazônia Oriental: desempenho atual e perspectivas futuras. Série Amazônia: IMAZON, 1996. P. 1- 44.

AVILA, M. The economics of agroforestry systems. Paia: Financial and Economic Analysis of Agroforestry Systems, 1992. P. 77-94.

BANDY, D.; GARRITY, D. P.; SANCHEZ, P. El problema mundial de al gricultura de tala y queima. Agrofloresteria en las Américas, v.1, n.3, p. 14-20, 1994.

BEER, J.; LUCAS, C.; KAPP, G. Reforestación com sistemas agrosilviculturales permenetes vrs. plantaciones puras. Agroforesteria en las Américas, v.1, n.3, p. 21-25, 1994.

BRASIL. Ministério da Ciência e Tecnologia. Divulgação das estimativas oficiais do desflorestamento bruto na Amazônia. http:/www.MCT.gov.br/ (04 Dezembro de 1999). 
BROONKIRD, S.A.; FERNANDES, E.C.M.; NAIR, P.K.R. Forest villages: an agrofloresty approach to rehabilitating forest land degraded by shifiting cultivation in Thailand. Agroflorestry Systems, v.2, p. 87-102, 1984.

BUDOWSKI, G. Aplicabilidad de los sistemas agroforestais. In: SEMINÁRIO SOBRE PLANEJAMENTO DE PROJETOS AUTO-SUSTENTAVEIS DE LENHA PARA AMÉRICA LATINA E CARIBE, Turrialba, 1991. Anais. TURRIALBA: FAO, 1991. v.1, p161-167.

CANTARUTTI, R.B. Transferência de nitrogênio de leguminosas para gramíneas. In: SIMPÓSIO INTERNACIONAL SOBRE PRODUÇÃO ANIMAL EM PASTEJO, 1., Viçosa , 1997. Anais. Viçosa: UFV, DZO, 1997. p.349-379.

CANTO, A. C.; SILVA, S. E. L.; NEVES, E. J. M. Sistemas agroflorestais na Amazônia Ocidental: aspectos técnicos e econômicos. In: ENCONTRO BRASILEIRO DE ECONOMIA E PLANEJAMENTO FLORESTAL, 2., Curitiba, 1991. Anais. Colombo: EMBRAPA, CNPFlorestas, 1992. p. 23-36.

CARVALHO, M.M. Recuperação de pastagens degradadas. Coronel Pacheco: EMBRAPA, CNPGL, 1993. 51p. (EMBRAPA. CNPGL. Documentos, 55).

CARVALHO, M.M. Recuperação de pastagens degradadas em áreas de relevo acidentado. In: DIAS, L.E.; MELLO, J.W.V. (Ed.) Recuperação de áreas degradadas. Viçosa: UFV, DPS; Sociedade Brasileira de Recuperação de Áreas Degradadas, 1998. p.149-162.

CONNOR, D. J. Plant strees factors and their influence on production of agroforestry plant association. In: HUXLEY, P. Plant research and agroforestry. Nairobi: ICRAF, 1993. p. 401-426.

COSTA, F.A. Agricultura familiar em transformação na Amazônia: o caso de Capitão Poço e suas implicações na política e no planejamento agrícolas regionais. In: HOMMA, A.K.O.(Ed.) Amazônia meio ambiente desenvolvimento agrícola. Brasília: Embrapa, 1998a. p.177-319.

COSTA, F.A. A dimensão sócio - econômica da produção rural familiar da Amazônia. In: Estratégias e Desenvolvimento Sustentável na Amazônia e Agenda 21. 1998b. $63 \mathrm{p}$.

COUTO, L.; FERNANDES, E. N.; YARED, J.A.G. O estado da arte dos sistemas agroflorestais. VIÇOSA: UFV, 1992. 80p.

CURRENT, D.; LUTZ, E. A preliminary economic andinstitutional evaluation of selected agroforestry projects in Central America. Washington: The Word Bank, Environment Department Division, 1990. 100p. (Working Paper, 1992-38) 
CURRENT, D.; LUTZ, E.; SCHERR, S. Adopción agrícola y benefícios econômicos de la agroforesteria: experiencia en América Central y el Caribe. Turrialba: CATIE; IFPRI; PNUD, 1995a. 48p. (CATIE. Série Técnica. Informe Técnico)

CURRENT, D.; LUTZ, E.; SCHERR, S. The costs and benefits of agroforestry to farmers. The World Bank Research Observer, v.10, n. 2, 151-180, 1995 b.

DIAS, M.C.; XAVIER, J.J.B.N.; BARRETO, J. F. Estudo da cadeia produtiva da mandioca no Amazonas. Manaus: EMBRAPA, CPAA, 1997. 28p.

DIAS FILHO, M.B. Pastagens cultivadas na Amazônia oriental brasileira: processos e causas de degradação e estratégias de recuperação. In: DIAS, L.E.; MELLO, J.W.V. (Ed.) Recuperação de áreas degradadas. Viçosa: UFV, DPS; Sociedade Brasileira de Recuperação de Áreas Degradadas, 1998. p.135-149.

DUBOIS, J. C. L. Manual agroflorestal para a Amazônia. Rio de Janeiro: REBRAF, 1996. v.1, 228p.

EMPRESA BRASILEIRA DE PESQUISA AGROPECUÁRIA. UEPAE de Manaus. Relatório Técnico anual . Manaus, 1981. 202p.

FALESI, I.C. Ecossistema de pastagem cultivada na Amazônia brasileira. Belém: EMBRAPA, CPATU, 1976. 193p. (EMBRAPA. CPATU. Boletim Técnico, 1).

FAO. Tropical forest resources. Rome, 1982. 188p.

FARRELL, J.; ALTIERI, M. A. Tradicional farming systems of south-central Chile whith special enphasis on agroforestry. Agroforestry Systems, v.2, n.1, p. 3-18, 1984.

FEARNSIDE, P.M. Agricultura na amazônia e tipos de agricultura: padrões e tendências. Cadernos do Núcleo de Altos Estudos Amazônicos, n.10, p.197-252, 1997.

FEARNSIDE, P.M. Reconsiderações do cultivo contínuo na Amazônia. Revista Brasileira de Biologia, v.50, n.4, p. 833-840, 1990.

FEARNSIDE, P. M. Agro-silvicultura na política de desenvolvimento na Amazônia brasileira: a importância e os limites de seu uso em áreas degradadas. Capítulo 19. UNESCO/Oxford University Press, Paris. 1996. p 293-312.

FEARNSIDE, P. M Agrosilvicultura na política de desenvilvimento na Amazônia Brasileira: a importância e os limites de seu uso em áreas degradadas. In: GASCON, C.; MOUTINHO, P. (Ed.) Floresta Amazônica: dinâmica, regeneração e manejo. Manaus: INPA, 1998. 373 pp. 
FERNANDES, E.C.M.; MATOS, J.C.S.; ARCO-VERDE, M. F.; LUDEWIGS, T. Estratégias agroflorestais para redução das limitações químicas do solo para produção de fibra e alimento na Amazônia Ocidental. DOCUMENTO EMBRAPA/CPAA, Manaus 1995. p.207-224.

FISCH,G.; MARENGO,J.A.; NOBRE,C.A. Uma revisão geral sobre o clima da Amazônia. Acta Amazonica, v.28, n.2, p.101-26, jun.1998.

FLORES, M. X.; QUIRINO, T. R.; NASCIMENTO, J. C.; RODRIGUES, G. S.; BUSCHINELLI, C. Pesquisa para agricultura auto-sustentável: perspectivas de política e organização da EMBRAPA. Brasília: EMBRAPA, SEA, 1991. 28p (EMBRAPA. SEA. Documentos, 5).

GASPAROTO, L.; PEREIRA, F. A.; LIMA, M. I. P. M. Enfermidade da seringueira no Brasil. Manaus: EMBRAPA, CPAA, 1990. 169p (EMBRAPA. CPAA Circular Técnica, 3).

GLOVER, N.; BEER, J. Nutrient cycling in two tradicional american agroforestry systems. Agroforestry Systems, v.4, n.2, p. 77-87, 1986.

GOODLAND, R.G. The concept of environmental sustainability. Annual Review of Ecology and Systematics, v.26, p. 1-25, 1995.

HOMMA, A.K.O; CONTO, A.J.; FERREIRA, C.A.P.; CARVALHO, R.A.; WALKER, R.T. A dinâmica da extração madeireira no estado do Pará. In: HOMMA, A.K.O. (Ed.) Amazônia meio ambiente e desenvolvimento agrícola. Brasília: EMBRAPA, 1998. p.770 - 787.

HUXLEY, P. A. Plant research and agroforestry. Naiorobi: ICRAF, 1983. 617p.

INSTITUTO DE DESENVOLVIMENTO AGROPECUÁRIO DO ESTADO DO AMAZONAS (IDAM). Coordenadoria de Elaboração, Acompanhamento e Avaliação de Programas e Projetos. Relatório de atividades. Manaus, 1997. 58p.

INSTITUTO SUPERIOR DE ADMINISTRAÇÃO E ECONOMIA DA AMAZÔNIA (ISA). Projeto potencialidades regionais. Manaus, 1997. 95p.

KANG, B.T.; WILSON, G. F. The development of alley cropping as a promision agroforestry technology. In: STEPPLER, H.A.; NAIR, P.K.R (Ed.) Agroforestry: a decade of development. Nairobi: ICARF, 1987. p 224-227.

KING, K.F.S, Agriculture (The Taungya system). Bulletin No.1, Ibadan: University of Ibadan, Departament of Forestry, 1968. 38p.

KLEMPERER, W. D. Forest resource economics and finance. New York: Mcgraw Hill., 437p., 1996. 
KITAMURA, P. C. Desenvolvimento sustentável: uma abordagem para as questões ambientais da Amazônia. Campinas, 1994. 298 p. Tese (Doutorado) Universidade Estadual de Campinas.

LINDGREN, B. O. The use of agroforesty to improve the productivity of converted tropical land. Nairobi: ICRAF, 1982. p. 37-49.

MACEDO, M.C.M. Recuperação de áreas degradadas: pastagens e cultivos intensivos. In: CONGRESSO BRASILEIRO DE CIÊNCIAS DO SOLO, 7., Goiânia, 1993. Anais. Goiânia: SBSC, 1993. p.71-72.

MACEDO, M.C.M. Pastagens no ecossistema do cerrado: pesquisas para o desenvolvimento sustentável. In: SIMPÓSIO SOBRE PASTAGENS NOS ECOSSISTEMAS BRASILEIROS - PESQUISAS PARA O DESENVOLVIMENTO SUSTENTÁVEL, 32., Brasília, 1995. Anais. Brasília: SBZ, 1995. p.28-62.

MACEDO, M.C.M; ZIMMER, A.H. Sistema pasto-lavoura e seus efeitos na produtividade agropecuária. In SIMPÓSIO SOBRE ECOSSISTEMAS DE PASTAGENS, 2., Jaboticabal, 1993. Anais. Jaboticabal: FUNEP, 1993. p.216245.

McKERROW, A. J. Nutrient stocks in abandoned pastures of the central Amazon basin prior to and following cutting and burning. Raleigh, 1992. 116p. Thesis. (M.S.) - North Carolina State University.

MEIRELLES, N.M.F. Degradação de pastagens: critérios de avaliação. In: ENCONTRO SOBRE RECUPERAÇÃO DE PASTAGENS, 1., Nova Odessa, 1993. Anais. Nova Odessa: Instituto de Zootecnia, 1993. p. 27-48.

MIRITI, M. N. Regeneração florestal em pastagens abandonadas na Amazônia Central: competição, predação e dispersão de sementes In: GASCON, C.; MOUTINHO, P. (Ed.). Floresta Amazônica: dinâmica, regeneração e manejo. Manaus: INPA, 1998. cap. 12, p. 179-190.

MONTAGNINE, F. Sistemas agroflorestais: principios y aplicaciones en los tropicos. 2.ed. San José: Organización para Estudios Tropicales, 1992. 622p.

MONTOYA, L. J. E BAGGIO, A. J. Estudo econômico da introdução de mudas altas para sombreamento de pastagens. In: ENCONTRO BRASILEIRO DE ECONOMIA E PLANEJAMENTO FLORESTAL, 2., Curitiba, 1991. Anais. Curitiba: EMBRAPA, CNP Floresta, 1991. p.171-185.

NAIR, P. K. R. Agroforestry in the context of land clearing and development in the tropics. Nairobi: ICRAF, 1985a. pp. 1-11. (Working Paper 33). 
NAIR, P. K. R. Classification of agroforestry systems. Agroforestry Systems, v.3, p.97-128, 1985b.

NAIR, P.K.R. Agroforestry systems inventory. Agroforestry Systems, v.5, p.301317, 1987.

NAIR, P. K. R. Agroforestry systems in the tropics. Dordrecht: Kluwer Academic, 1989. 664 p. (Forestry Sciences, 31)

NAIR, P. K. R. An introduction to agroforestry. Dordrecht: Kluwer Academic, 1993. 499p.

NAIR, P.K.R.; RAO, N. S. S. Microbiology of the root region of coconut and cacao mixed cropping. Plant and Soil, v.46, p. 511-519, 1977.

NASCIMENTO JÚNIOR, D. Ecossistemas de pastagens cultivadas. In: SIMPÓSIO SOBRE MANEJO DE PASTAGEM, 15., Piracicaba, 1998. Anais. Piracicaba: FEALQ, 1998. p. 271-296.

NASCIMENTO JÚNIOR, D.; QUEIROZ, D.S.; SANTOS, M.V.F. Degradação das pastagens e critérios para avaliação. In: SIMPÓSIO SOBRE MANEJO DE PASTAGEM, 11., Piracicaba, 1994. Anais. Piracicaba: FEALQ, 1994. P.107151.

NEPSTAD, D. C.; UHL, C.; SERRÃO, E. A. S. Recuperation of a degraded amazonian landscape: forest recovery and agricultural restoration. Ambio, v.20, p. 248-255, 1991.

NODA, H.; NODA, S.N. Produção agropecuária. In: Amazônia: uma proposta interdisciplinar de educação ambiental. M.M.A./IBAMA, Brasília. 1994. p.133153.

NODA, H.; SOUZA, L. A. G.; FONSECA, O. J. M. Duas décadas de contribuição do INPA a pesquisa agronômica no trópico úmido. Manaus: INPA, 1997. $332 \mathrm{p}$

NODA, S.N.; PEREIRA, S.H. ; BRANCO, F.M.C.; NODA, H. O trabalho nos sistemas de produção de agriculturas familiares na Várzea do Estado do Amazonas MCT/INPA. In: NODA, H.; SOUZA, L.A.G. de; FONSECA, O.J.M. da (Ed.) Duas décadas de contribuição do INPA à pesquisa agronômica no trópico úmido. Manaus: INPA, 1997. P. 332.

OKIGBO, B. N. Improved permanent production systems as na alternative to shifting cultivation. Rome: FAO, 1985. 100 p. (FAO Soils Bulletin, 53)

OLIVEIRA, S. J. M.; VOSTI, S. A. Aspectos financeiros de sistemas agroflorestais em Ouro Preto do Oeste. Rondônia: EMBRAPA, RONDÔNIA, 1997. 7p. (Boletim Técnico) 
PASSOS, C. A. M.; COUTO, L. Sistemas agroflorestais potenciais para o Estado do Mato Grosso do Sul. In: SEMINÁRIO SOBRE SISTEMAS FLORESTAIS PARA O MATO GROSSO DO SUL, 1., Dourados, 1997. Resumos. Dourados: EMBRAPA, CPAO, 1997. p.16-22. (EMBRAPA. CPAO. Documentos, 10).

PREISINGER, H. Efeitos de padrões especiais prévios da vegetação sobre o desenvolvimento de espécies de plantas úteis perenes em sistemas de policultivos na área experimental. In: GASPAROTO, L. PRESINGER, H. P. (Ed.). Recuperação de áreas degradadas e abandonadas através de sistemas de policultivo. Manaus: EMBRAPA, CPAA, 1996. p. 26-76

PROJETO CUT/CONTAG Desenvolvimento e Sindicalismo Rural no Brasil. São Paulo, 1989. p. 137-162.

REICHE, C. E. Implicaciones economicas del componente agroflorestal. Turrialba: CATIE, 1983. 19p.

RODIGHERI, H. R. Rentabilidade econômica comparativa entre plantios florestais e sistemas agroflorestais com erva-mate, eucalipto e pinus e as culturas do feijão, milho, soja e trigo. Colombo: EMBRAPA, CNPF, 1997. 35. p. (EMBRAPA. CNPF. Circular Técnica, 26).

RODRIGUES, F. M. Rentabilidade de sistemas de produção agroflorestais e de pecuária para a Região Amazônica - um estudo de caso. Viçosa, 1997. 108p. Tese (Doutorado)- Universidade Federal de Viçosa.

RODRIGUEZ, L.C. E.; BUENO, A. R. S.; RODRIGUES, F. Rotações de eucalipto mais longas: análise volumétrica e econômica. Scientia Forestalis, n. 51, p. 1528, jun. 1997.

RUTHEMBERG, H. Farming systems in the tropics. Oxford: Claredon Press, 1980.

SCHERR, S. J. Econimic factors in farmer adoption of agroforestry: patterns observed in Western Kenya. Separata de World Development, v. 23, n.5, p.787804, 1995.

SENA GOMES, A. R.. Sistemas agrossilviculturais do sudeste da Bahia. In: ENCONTRO BRASILEIRO DE ECONOMIA E PLANEJAMENTO FLORESTAL, 2., Curitiba, 1992. Anais. Curitiba: EMBRAPA, CNP Floresta, 1992. p. 109-122.

SERRÃO, E. A. Pasture development and carbon emission/accumulation in the Amazon:_topic for discussion. Tropical forestry response options to global climate change. Washington: Editora: Environmemtal Protection Agency. 1990.p. 
SERRÃO, E. A. S.; HOMMA, A. K. O. Agriculture in the Amazon: the question of sustainability. Washington: Committee for Agriculture Sustainability and Environment in the Humid Tropics, 1991. 100 p.

SERRÃO, E. A.; TOLEDO, J. M. The search for sustainability in amazonian pastures. In: ANDERSON, A. B. (Ed.) Alternatives to deforestation: steps toward sustainable use of the Amazon forest. New York: Columbia University Press, 1990. p. 195-214.

SERRÃO, E.A.S.; FALESI, I.C.; VEIGA, J.B.; TEIXEIRA NETO, J.F. Produtividade de pastagens cultivadas em solos de baixa fertilidade das áreas de floresta da Amazônia brasileira. In: TERGAS, L.E.; SANCHEZ, P.A.; SERRÃO, E.A.S. (Ed.) Produção de pastagens em solos ácidos dos trópicos. Brasília: CIAT; EMBRAPA, 1982. p.219-252.

SMITH, N. J. H.; FALESI, I. C.; ALVIN, P. T. Agroforestry trajectories among smallholders in the Brazilian Amazon: innovation and resiliency in pioneer and older settled areas. Ecological Economics, v. 18, n. 1, p. 15-27, 1996,

SPAIN, J.M.; GUALDRON, R. Degradación e rehabilitación de pasturas. In: LASCANO, C.; SPAIN, J.M. (Ed.) Establecimiento y renovación de pasturas. Cali: CIAT, 1991. 426p.

SWINKELS, R. A.; SCHERR, S. J. Economic analysis of agroforestry technologies: an annoted bibliography. Nairobi: ICRAF, 1991. 215 p.

THUESEN, H. G; FABRYCKY, W. J; TAVESEN, G. J. Ingenieria economica. Madrid: 1991. 592p.

TONIOLO, A.; UHL, C. Perspectivas econômicas e ecológicas da agricultura na Amazônia Oriental. In: ALMEIDA, O. (Ed.) A evolução da fronteira Amazônica, oportunidades para um desenvolvimento sustentável. Belém: IMAZON, 1996. p. 67-99.

VAN-LEEUWEN, J. ; GOMES, B. M. O pomar caseiro na região de Manaus, Amazonas, um importante sistema agroflorestal tradicional. 1999. http://www.inpa.gov.br/cpca/joha-pomar.html. (30 Novembro 1999).

VAN-LEEUWEN, J.; PEREIRA, M. M.; COSTA, F. C. T.; CATIQUE, F. A. Transforming shifting cultivation fields into productive forests. In: CONGRESSO BRASILEIRO SOBRE SISTEMAS AGROFLORESTAIS, 1.; ENCONTRO SOBRE SISTEMAS AGROFLORESTAIS NOS PAÍSES DO MERCOSUL, 1., Porto Velho, 1994. Anais. Colombo: EMBRAPA, 1994. v.2, p. 431-438. 
VEIGA, J.B.; FALESI, I.C. Recomendação e prática de adubação em pastagens cultivadas na Amazônia brasileira. In: MATOS, H.B.; WERNER, J.C.; YAMADA, T.; MALAVOLTA, E. (Ed.) Calagem e adubação de pastagens. Piracicaba: POTAFOS, 1986. p.257-282.

VEIGA, J.B.; SERRÃO, E.A.S. Recuperacion de pastures en la region este de la Amazonia brasileña. Pasturas Tropicales, v.9, n.3, p.40-43, 1987.

VILAS BOAS, O. Uma breve descrição dos Sistemas Agroflorestais na América Latina. IF. Série Registros São Paulo, n.8, p.1-16, 1991.

VÍQUEZ, E. P. A.; OÑORO, P.; SOLANO, R. Caracterización del huerto mixto tropical. "La asunción", masatepe, Nicaragua. Agroforesteria en las Américas, v.1, n.2, p.5-9, 1994.

WALKER, R.T.; HOMMA, A.K.O.; SCATENA, F.N.; ROCHA, A.C.P.N.; SANTOS, A.I.M.; CONTO, A.J; RODRIGUEZ-PEDRAZA, C.D.; FERREIRA, C.A.P.; OLIVEIRA, P.M. Sustainable farm management in the Amazon piedmont. In: CONGRESSO BRASILEIRO DE ECONOMIA E SOCIOLOGIA RURAL, No. 34. Ilhéus, 1993. Anais. Ilhéus: SOBER, 1993. v.2, p. 706-720.

WALKER, R.T.; HOMMA, A.K.O.; SCATENA, F.N.; ROCHA, A.C.P.N.; SANTOS, A.I.M.; CONTO, A.J; RODRIGUEZ-PEDRAZA, C.D.; FERREIRA, C.A.P.; OLIVEIRA, P.M.; CARVALHO, R.A. A Evolução da Cobertura do solo nas äreas de pequenos Produtores na Transamazônica. In: HOMMA, A.K.O. (Ed.) Amazônia meio ambiente desenvolvimeto agrícola. Brasília: EMBRAPA, 1998. p.322-343.

YOUNG, A. Agroforestry for soil conservation. Nairobi: ICRAF, 1990. 276 p.

ZIMMER, A.H.; EUCLIDES FILHO, K. As pastagens e a pecuária de corte brasileira. In: SIMPÓSIO INTERNACIONAL SOBRE PRODUÇÃO ANIMAL EM PASTEJO, 1., 1997, Viçosa. Anais. Viçosa: UFV, DZO, 1997. p.349-379.

ZIMMER, A.H.; MACEDO, M.C.M.; BARCELLOS, A.O.; KICHEL, A.N. Estabelecimento e recuperação de pastagens de Brachiaria. In: SIMPÓSIO SOBRE MANEJO DE PASTAGEM, 11., Piracicaba, 1994. Anais. Piracicaba: FEALQ, 1994. P. 153-208. 